
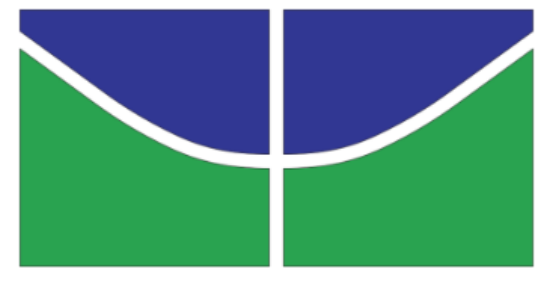

UNIVERSIDADE DE BRASÍLIA INSTITUTO DE CIÊNCIAS BIOLÓGICAS DEPARTAMENTO DE FITOPATOLOGIA PROGRAMA DE PÓS-GRADUAÇÃO EM FITOPATOLOGIA

NEMATOIDES ASSOCIADOS À CULTURA DA SOJA NA REGIÃO INTEGRADA DE DESENVOLVIMENTO DO DISTRITO FEDERAL E ENTORNO-RIDE

PEDRO VICTOR VERLAGE ALVES

BRASÍLIA-DF 


\title{
NEMATOIDES ASSOCIADOS À CULTURA DA SOJA NA REGIÃO INTEGRADA DE DESENVOLVIMENTO DO DISTRITO FEDERAL E ENTORNO-RIDE
}

\begin{abstract}
Dissertação apresentada ao Programa de Pós-graduação em Fitopatologia, do Departamento de Fitopatologia do Instituto de ciências Biológicas da Universidade de Brasília, como requisito parcial para obtenção do grau de Mestre em Fitopatologia.
\end{abstract}

Orientador: Prof. Cleber Furlanetto 


\title{
FICHA CATALOGRÁFICA
}

\author{
Alves, Pedro Victor Verlage.
}

Nematoides Associados à Cultura da Soja na Região Integrada de Desenvolvimento do Distrito Federal e Entorno-RIDE/ Pedro Victor Verlage Alves.

Brasília, 2015.

66 p.: il.

Dissertação de mestrado. Programa de Pós-graduação em Fitopatologia, Universidade de Brasília, Brasília.

1. Palavra-chave Doenças - grãos - Centro-Oeste

I. Universidade de Brasília. PPG/FIT.

II. Título de Mestre. 


\section{DEDICATÓRIA}

Dedico este trabalho aos meus

avós e toda minha família. 


\section{AGRADECIMENTOS}

A princípio gostaria de agradecer a Deus pelos dons a mim oferecidos e a sorte de ter uma família que sempre me apoiou nas minhas decisões.

Mas não poderia de deixar de agradecer a meu orientador Cleber Furlanetto e professores Juvenil Enrique Cares, Adalberto Corrêa Café filho, Carlos Hidemi Uesugi, Helson Mário Martins do Vale, José Carmine Dianese, Luiz Eduardo Bassay Blum, Marisa Álvares da Silva Velloso Ferreira, Renato de Oliveira Resende, Rita de Cássia Pereira Carvalho, e colegas Guilherme Alvares Lapidus, Ícaro de Sousa Ribeiro, Josiane Goulart Batista, Juliana Osse de Souza, Kamila Pereira de Araújo, Leydy Lorena Mendoza Tobar, Marcella Teles dos Reis, Nédio Rodrigo Tormen, Rafaela Cristina Ferreira Borges, Rayane dos Santos Lima, Vanessa da Silva Mattos, Amanda de Melo Gonçalves, Cecília da Silva Rodrigues, Cleia dos Santos Cabral, Fabiane Silva Dorosci Brito, Frederick Mendes Aguiar, Gláucia Garcia Figueiro, Jessica da Mata dos Santos Monteiro, Justino José Dias

Neto, Larissa de Brito Caixeta, Nancy Eunice Niño Castañeda, William Rosa de Oliveira Soares, Elenice, Karina, Carine, Carina, Carol, Ricardo, Josefa Neiane Goulart Batista, Alaerson Geraldine, Débora Gutieres e João, por partilharem conhecimento, experiência, companheirismo, e também, pelo incentivo à superação.

Agradeço ao Ribamar pela atenção nos processos burocráticos, ao Cézar, Arlindo e Marivaldo pela condução do transporte às fazendas do levantamento e à boa vontade.

Agradeço também aos alunos de PIBIC Deborah, Ramón e Thiago.

Agradeço também às instituições que me auxiliaram e financiaram, permitindo a viabilidade e desenvolvimento deste levantamento entre elas: Capes, FAPE-DF, UnB, Embrapa Soja, Tchê, Vegetal e SIAP.

Muito obrigado ao Dr. Valdir Pereira Dias por realizar a identificação dos nematoides de cisto.

Obrigado especial a Larissa de Souza Farias.

Saibam que sempre levarei todos nas minhas boas recordações. 
Trabalho realizado junto ao Departamento de Fitopatologia do Instituto de Ciências Biológicas da Universidade de Brasília, sob orientação do Professor Cleber Furlanetto, com apoio da CAPES e do Decanato de Extensão (DEX-UnB) Edital 03/2013.

\section{NEMATOIDES ASSOCIADOS À CULTURA DA SOJA NA REGIÃO INTEGRADA DE DESENVOLVIMENTO DO DISTRITO FEDERAL E ENTORNO-RIDE}

\section{PEDRO VICTOR VERLAGE ALVES}

DISSERTAÇÃO APROVADA em 30/09/2015 por:
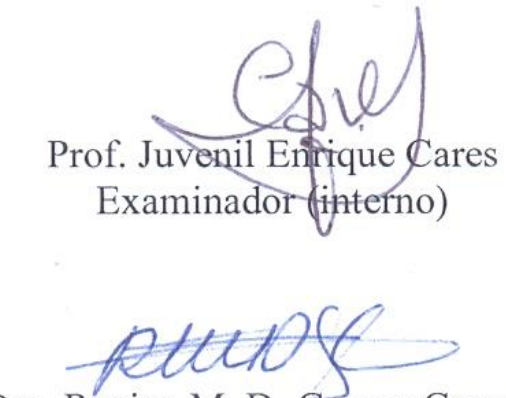

Dra. Regina M. D. Gomes Carneiro Examinadora (Externa)

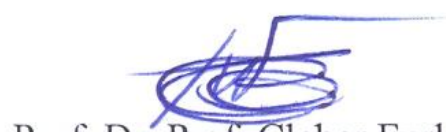

Prof. Dr. Prof. Cleber Furlanetto

Orientador (Presidente)

BRASÍLIA - DISTRITO FEDERAL

BRASIL 


\section{SUMÁRIO}

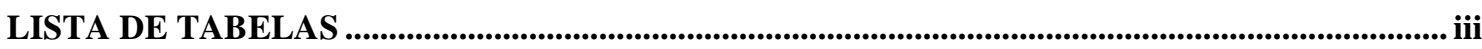

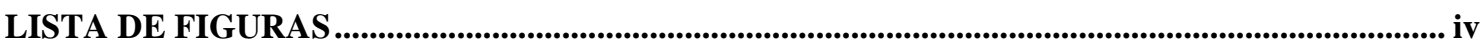

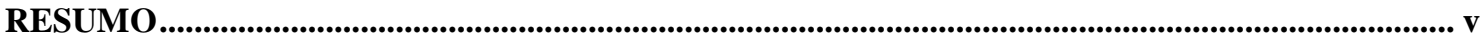

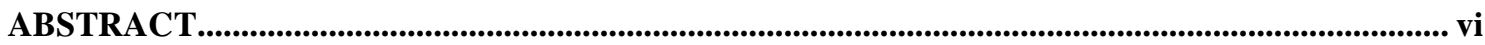

1 INTRODUÇÃO ....................................................................................................................................... 1

2 OBJETIVOS

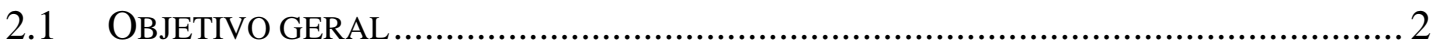

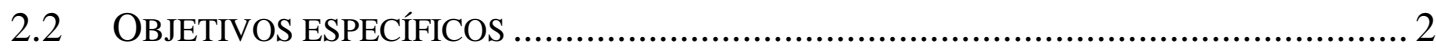

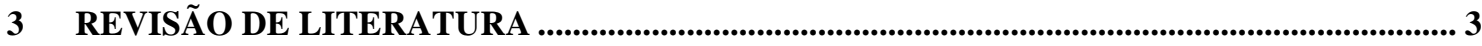

3.1 REGIÃo INTEGRADA DE DESENVOLVIMENTO DO Distrito FEDERAL E ENTORNO

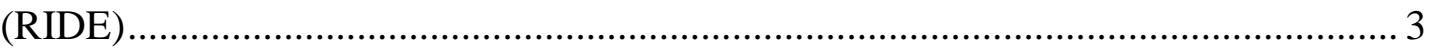

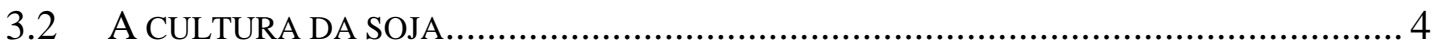

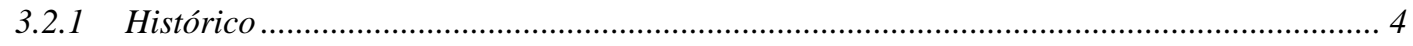

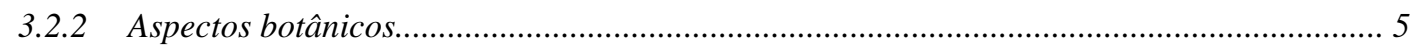

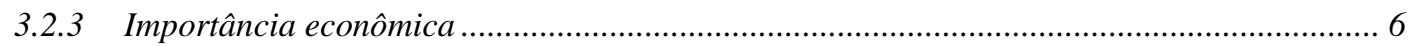

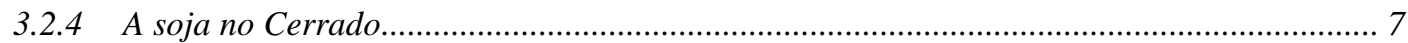

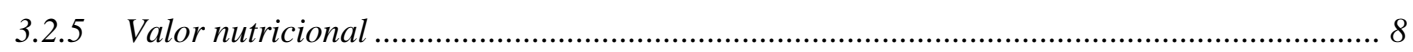

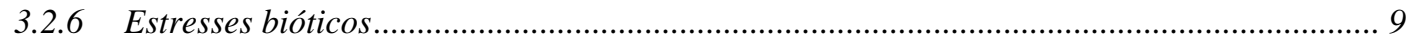

3.2.7 Nematoides parasitas da cultura da soja no Brasil ........................................................ 10

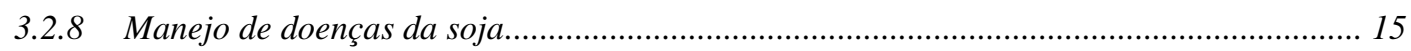

3.3 LEVANTAMENTO DE NEMATOIDES NA CULTURA DA SOJA ................................ 17

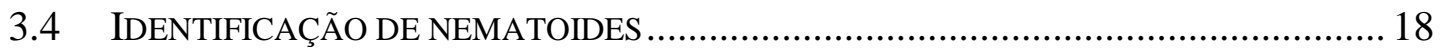

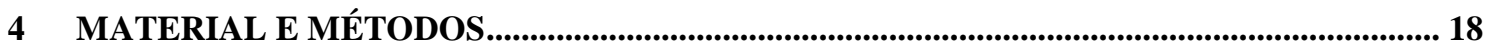

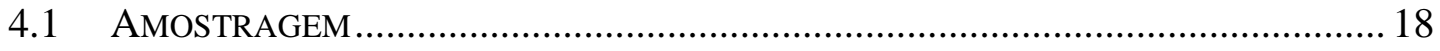

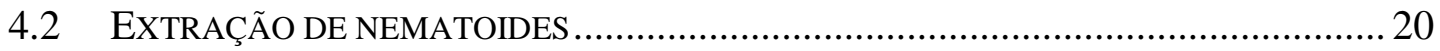

4.3 OBTENÇÃO DE POPULAÇÕES DE MELOIDOGYNE E DETERMINAÇÃO DE RAÇAS DE

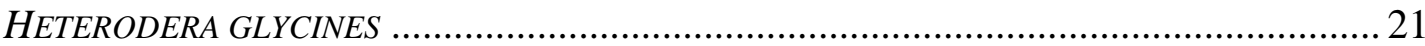

4.4 EXTRAÇÃO DE OVOS E J2 DE MELOIDOGYNE SPP. EM RAÍZES DE TOMATEIRO.... 21

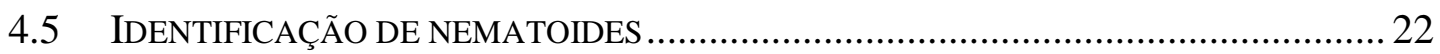

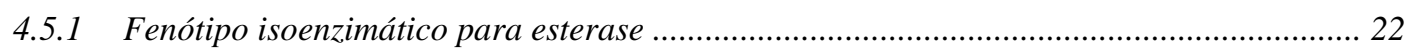

4.5.2 Extração de DNA genômico e identificação de Meloidogyne por PCR............................... 23 


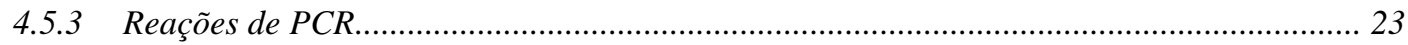

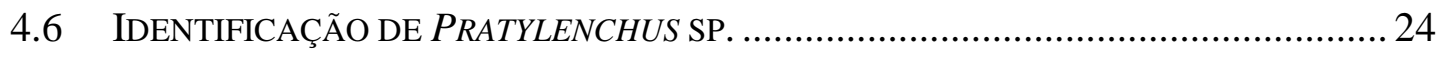

4.7 QUANTIFICAÇÃO DE PRATYLENCHUS, DETERMINAÇÃO DO NÍVEL DE INFESTAÇÃO E PRESERVAÇÃO EM SOLUÇÃO DE DESS-EDTA ….................................................. 25

4.8 FIXAÇÃO DE NEMATOIDESE PARA MICROSCOPIA ELETRÔNICA DE

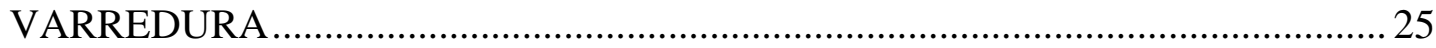

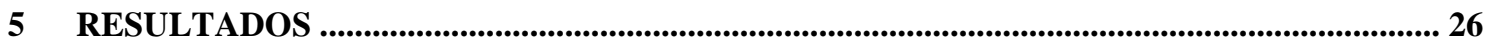

5.1 IDENTIFICAÇÃO E QUANTIFICAÇÃO DE PRATYLENCHUS ....................................... 26

5.2 IDENTIFICAÇÃO E QUANTIFICAÇÃO DE MELOIDOGYNE SPP................................ 32

5.3 QUANTIFICAÇÃO DE CISTOS E J2 DE HETERODERA GLYCINES E DETERMINAÇÃO DE

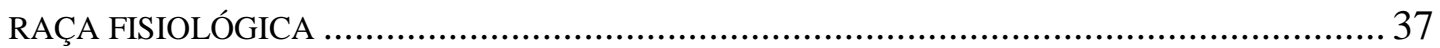

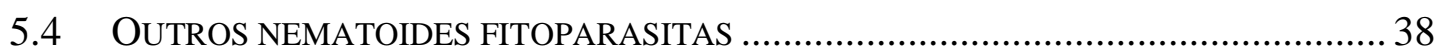

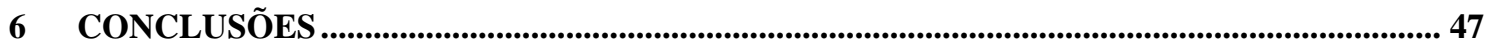

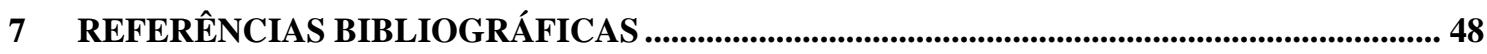

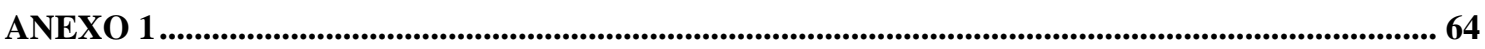

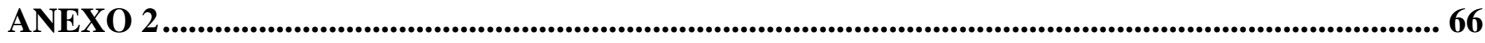




\section{LISTA DE TABELAS}

Tabela 1. Coordenadas geográficas de sítios de coleta de amostras nematológicas em municípios da RIDE.

Tabela 2. Características de marcadores SCAR espécie-específicos para Meloidogyne spp... 23 Tabela 3. Nível populacional em amostras de $300 \mathrm{cc}$ de solo de Pratylenchus brachyurus em municípios da RIDE-DF. 30

Tabela 4. Nematoides extraídos de raízes de soja coletadas em propriedades rurais da RIDE.

Tabela 5. Quantificação e identificação de populações de Meloidogyne spp. coletadas na RIDE 36

Tabela 6. Cistos e J2 de Heterodera glycines detectados em amostras de $300 \mathrm{cc}$ de solo em municípios da RIDE.

Tabela 7. Determinação de raças de Heterodera glycines em municípios da RIDE.

Tabela 8. Ocorrência simultânea de Pratylenchus brachyurus, Heterodera glycines e Meloidogyne spp. em municípios da RIDE a partir de amostras de $300 \mathrm{cc}$ de solo. 40

Tabela 9. Nível populacional de nematoides por amostra em municípios da RIDE-DF (nematoides/300cc de solo).

Tabela 10. Raça de Heterodera glycines em Cristalina-GO. 64

Tabela 11. Raça de Heterodera glycines em Luziânia-GO. 64

Tabela 12. Raça de Heterodera glycines no PAD-DF e Planaltina-GO. 65

Tabela 13. Raça de Heterodera glycines em Cabeceira Grande-MG e Unaí-MG .65 


\section{LISTA DE FIGURAS}

Figura 1. Mapa da Região Integrada de Desenvolvimento do Distrito Federal e Entorno (RIDE).

Figura 2. Mapa dos estados brasileiros produtores de soja.

Figura 3. Lavoura de soja com enfezamento de plantas em reboleiras causado por Pratylenchus brachyurus. 20

Figura 4. Micrografias ao microscópio eletrônico de varredura com vista lateral da região cefálica (A) e da cauda (B) de Pratylenchus brachyurus.

Figura 5. Micrografias ao microscópio Óptico de Pratylenchus brachyurus. A- região anterior; B- região Posterior mostrando a vulva, ânus e cauda conóide. 28

Figura 6. Fêmea de Pratylenchus brachyurus.

Figura 7. Gel de agarose da amplificação por PCR de fragmentos de DNA genômico de 267 pb referentes a 8 populações de Pratylenchus brachyurus (P1 a P8) coletadas na RIDE. M = marcador molecular $1 \mathrm{~Kb}$ Plus DNA Ladder.

Figura 8. Fenótipo de esterase (J3) em populações de Meloidogyne javanica coletadas na RIDE.

Figura 9. Gel de poliacrilamida com fenótipo Esterase A2 detectado a partir de fêmeas individuais extraídas de raiz de tomateiro (amostra A11). 33

Figura 10. PCR com primers específicos para Meloidogyne incognita e M. javanica. $\mathrm{M}=1 \mathrm{~Kb}$ Plus DNA Ladder; $\mathrm{pb}=$ pares de base; $\mathrm{A}=$ amostra.

Figura 11. PCR com primers específicos para Meloidogyne arenaria e M. hapla. $\mathrm{M}=1 \mathrm{~Kb}$ Plus DNA Ladder; $\mathrm{pb}=$ pares de base; $\mathrm{A}=$ amostra. 34 


\section{RESUMO}

A Região Integrada de Desenvolvimento do Distrito Federal e Entorno (RIDE) é composta por 22 municípios distribuídos pelos Estados de Goiás (19), Minas Gerais (3) e Distrito Federal. Nessa região a principal commodity é a soja. Um dos principais problemas fitossanitários desta cultura é causado pelo parasitismo de nematoides. Com o objetivo de conhecer os nematoides associados à cultura da soja na RIDE foi realizado um levantamento visando a identificação e quantificação de espécies fitoparasitas relevantes de nematoides associados. Foram coletadas 70 amostras de solo e de plantas de soja em municípios da RIDE para a extração de nematoides de solo e de raízes. Após a extração, os nematoides foram identificados a nível de gênero, espécie e raça e quantificados por grama de raiz e 300 cc de solo. Pratylenchus brachyurus foi identificado por marcador molecular e com base em caracteres morfológicos e morfométricos, bem como os demais gêneros identificados. A identificação de nematoides de galha foi realizada com base no fenótipo das esterases e em marcadores moleculares mediante reações de PCR. Cistos de Heterodera glycines foram extraídos dos solos visando a inoculação de ovos e J2 em plantas de soja hospedeirodiferenciadoras para a identificação de raças fisiológicas. Identificou-se Pratylenchus brachyurus, Meloidogyne arenaria (EST-A2), M. javanica (EST-J3), M. incognita e Heterodera glycines raça 3 como os principais nematoides causadores de dano econômico à soja na RIDE. Os níveis de infestação para Meloidogyne spp., H. glycines e P. brachyurus variaram entre as amostras analisadas para os diferentes municípios amostrados. Heterodera glycines, Rotylenchulus reniformis e Tylenchorhynchus sp. tiveram o seu primeiro relato no Distrito Federal para a cultura da soja. Foram encontrados também outros nematoides fitoparasitas como Helicotylenchus spp., Criconemoides spp., Trichodorus spp., além de nematoides micófagos (Aphelenchus e Aphelenchoides), bacteriófagos (Acrobeles e Rhabditis), predadores (Mononchida) e onívoros (Dorylaimida) e outros Tylenchina não identificados. 


\begin{abstract}
The Integrated Development Region of the Federal District and surrounding areas (RIDE) is composed of 22 municipalities distributed in the states of Goiás (19), Minas Gerais (3) and the Federal District. In this region the main commodity is soybean. One of the main phytosanitary problems of this crop is caused by parasitic nematodes. In order to know the nematodes associated with soybean in the RIDE was conducted a survey aimed to identifying and quantify relevant phytoparasitic species and associated nematodes. Seventy samples were collected from soil and soybean roots in the RIDE municipalities for the extraction of soil and root nematodes. After extraction, the nematodes were identified to genus, species and race when possible, then quantified by gram of root and $300 \mathrm{cc}$ of soil. Pratylenchus brachyurus was identified by molecular markers and based on morphological and morphometric characters, as other nematodes. Identification of root-knot nematodes was based on the phenotype of esterase and molecular markers using PCR reactions. Cists of Heterodera glycines were extracted from the soil aiming to inoculate eggs and $\mathrm{J} 2$ in hostdifferentiating soybean genotypes for the identification of physiological races. It was identified Pratylenchus brachyurus, Meloidogyne arenaria (EST-A2), M. javanica (EST-J3), M. incognita and Heterodera glycines race 3 as the main cause of economic damage by nematodes to soybeans in the RIDE. Infestation levels for Meloidogyne spp., H. glycines and $P$. brachyrus varied among samples analyzed for the different sampled municipalities. This is the first report of Heterodera glycines, Rotylenchulus reniformis and Tylenchorhynchus $\mathrm{sp}$. in the Federal District to soybean crop. Also found other plant parasitic nematodes as Helicotylenchus spp., Criconemoides spp., Trichodorus spp., and mycophagous nematodes (Aphelenchus and Aphelenchoides), bacteriophages (Acrobeles and Rhabditis), predators (Mononchida) and omnivores (Dorylaimida) and other unidentified Tylenchina.
\end{abstract}




\section{INTRODUÇÃO}

A Região Integrada de Desenvolvimento econômico do Distrito Federal e Entorno (RIDE/DF) foi criada pela Lei Complementar $n^{\circ}$ 94, de 19 de fevereiro de 1998, e regulamentada pelo Decreto n. ${ }^{\circ}$ 7.469, de 04 de maio de 2011, para efeitos de articulação da ação administrativa da União, dos Estados de Goiás, Minas Gerais e do Distrito Federal. A RIDE é constituída por 22 municípios e o Distrito Federal (Sudeco, 2015).

Na RIDE a soja é a cultura que ostenta a maior área plantada, contribuindo fortemente para a economia da região (CONAB, 2015).

A soja, Glycine $\max$ (L.) Merril, é uma planta oleaginosa pertencente à família Leguminosae e subfamília Faboideae (Papilionoidea), apresentando fruto do tipo legume conhecido como vagem. Os grãos desta oleaginosa são de grande relevância no cenário mundial de alimentos, pois dele se extrai óleo e farelo, uma importante fonte de proteína vegetal (Hymowitz \& Newell, 1981; Sediyama, 2009).

O óleo é usado para alimentação humana e também tem uso industrial como na fabricação de biodiesel (Ferrari, et al., 2005). O farelo é utilizado principalmente como ração para a nutrição de aves e suínos. Cerca de $2 \%$ da proteína da soja produzida é destinada exclusivamente para a alimentação humana na forma de diferentes produtos como tofu, carne de soja ou derivados do leite de soja (Rosa et al., 2009).

O Brasil figura como o segundo maior produtor de soja no mundo, produziu 96,2 milhões de toneladas de grãos na safra 2014/2015 em uma área cultivada em torno de 32 milhões de hectares. A maior área plantada figurou-se no Centro-Oeste brasileiro com 13,9 milhões de hectares (CONAB, 2015). O Centro Oeste brasileiro tem se destacado na produção de soja pelo elevado nível tecnológico dos produtores, pelo aumento da área plantada com irrigação (pivô central), cultivares mais produtivas e acesso mais fácil a novas tecnologias (Hogan et al., 2002). 
Apesar da elevada produção brasileira de grãos, a produtividade da cultura da soja tem sido afetada por patógenos em geral, com destaque para os nematoides fitoparasitas. Perdas causadas por nematoides em soja no mundo são estimados em 32\% (Oerke et al., 1994).A cultura da soja é afetada por mais de 100 espécies de nematoides em todo o mundo, envolvendo cerca de 50 gêneros. No Brasil, os nematoides mais prejudiciais à cultura da soja têm sido os indutores de galhas em raízes (Meloidogyne spp.), o de cisto Heterodera glycines (Ichnohe, 1915), o das lesões radiculares Pratylenchus brachyurus (Goodfrey, 1929) Filipjev \& Stekhovem 1941, e o reniforme Rotylenchulus reniformis Linford \& Oliveira, 1940 (Dias et al., 2010).

Tendo em vista a importância dos nematoides fitoparasitas para a cultura da soja, estudos voltados ao levantamento de espécies de relevância econômica para cada região são fundamentais para o desenvolvimento do agronegócio da soja, servindo como base para estudos posteriores envolvendo a seleção de cultivares resistentes a nematoides, mapeamento de áreas infestadas e viabilização de métodos de controle adequados a cada área.

\section{OBJETIVOS}

\subsection{OBJETIVO GERAL}

Identificar as principais espécies de nematoides fitoparasitas da cultura da soja na RIDE.

\subsection{OBJETIVOS ESPECÍFICOS}

- Identificar nematoides de galhas por fenótipo de esterase e PCR específico (primers já disponibilizados em literatura); 
- Identificar nematoides das lesões por morfologia, morfometria e PCR específico (primers já disponibilizados em literatura);

- Identificar e quantificar nematoides fitoparasitas em geral associados a amostras de solo e raízes de plantas de soja;

- Quantificar cistos de H. glycines nas amostras coletadas e determinar raças das populações encontradas.

\section{REVISÃO DE LITERATURA}

\subsection{REGIÃO INTEGRADA DE DESENVOLVIMENTO DO DISTRITO FEDERAL E ENTORNO (RIDE)}

A Região Integrada de Desenvolvimento Econômico do Distrito Federal e Entorno (RIDE) foi criada pela Lei Complementar n. ${ }^{\circ}$ 94, de 19 de fevereiro de 1998, e regulamentada pelo Decreto n. ${ }^{\circ}$ 7.469, de 04 de maio de 2011, para efeitos de articulação da ação administrativa da União, sendo composta por 22 municípios distribuídos pelos Estados de Goiás (19), Minas Gerais (3) e Distrito Federal (Figura 1) (Sudeco, 2015). Na RIDE, a agricultura contribui com $1 \%$ do Produto Interno Bruto (PIB), com destaque para os municípios de Cristalina, Unaí, a Distrito Federal e Luziânia.

Devido à sua reduzida dimensão territorial, o Distrito Federal conta com 125.313 ha destinados à agricultura, sendo 10 mil hectares irrigados. A base agrícola do Distrito Federal se concentra nas Regiões Administrativas do Paranoá (PAD-DF) e Planaltina, esta última com os núcleos rurais de Rio Preto, Tabatinga e Taquara. A cultura da soja ocupa a maior área plantada (59 mil ha), seguida pela cultura do milho com 47,6 mil ha, feijão 14,5 mil ha e sorgo 5,2 mil ha (COOPA-DF, 2015). 


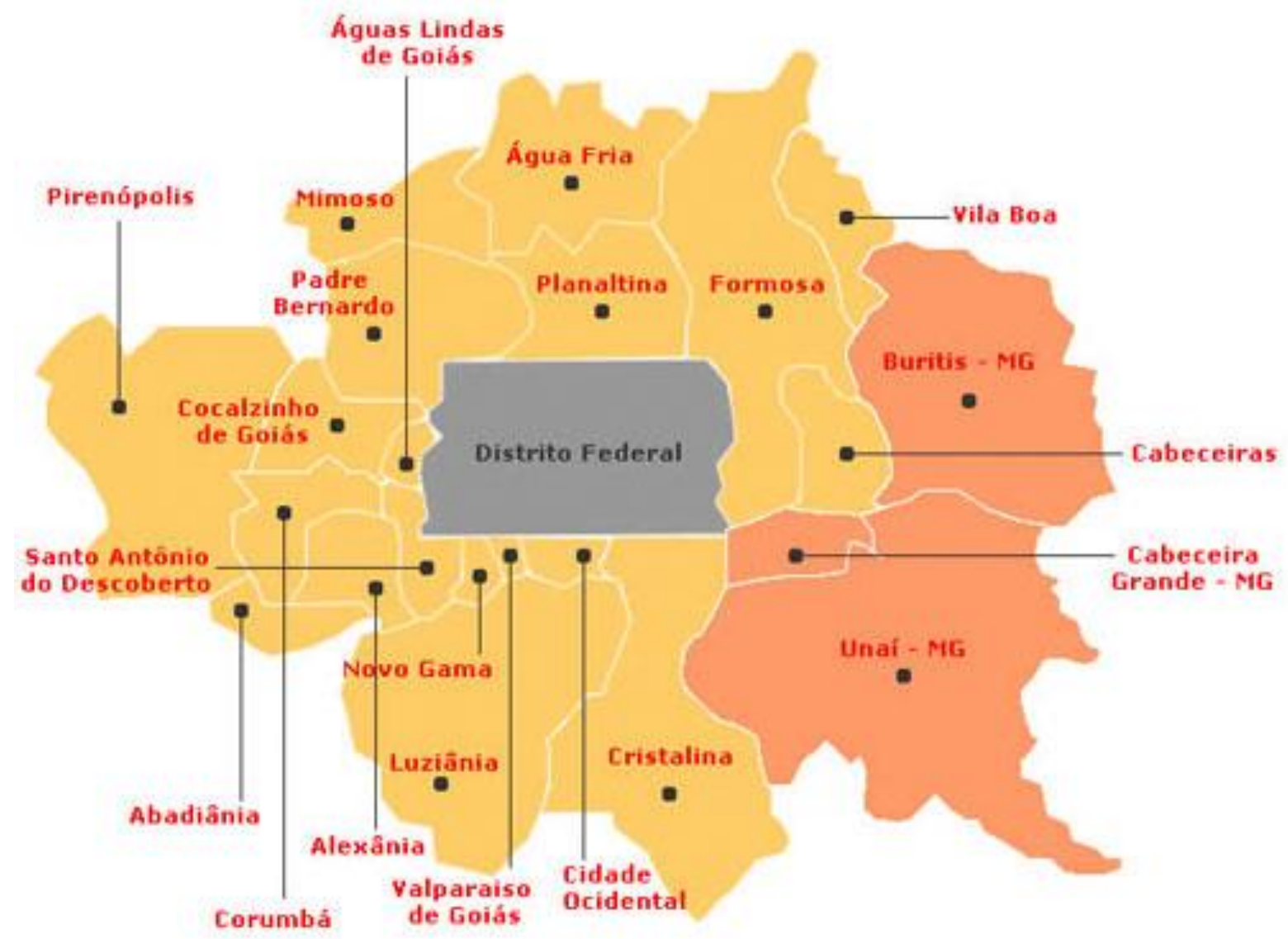

Figura 1. Mapa da Região Integrada de Desenvolvimento do Distrito Federal e Entorno (RIDE).

Fonte: <http://www.circuitomt.com.br/editorias/geral/13083-explosao-demografica-e-umadas-principais-preocupacoes-do-entorno.html>

\subsection{A CULTURA DA SOJA}

\subsubsection{Histórico}

A soja é originária da China, tendo sido cultivada até o primeiro século A.C. na península da Coréia e China central. Estima-se que a domesticação da soja tenha ocorrido de 1500-1100 A.C. (Schmutz et al., 2010).

A soja doméstica foi introduzida no Sudeste Asiático no século XV, adentrando a Europa em 1713 e América do Norte em 1765 (Cober et al., 2009). No Brasil a soja foi introduzida em 1882, oriunda dos Estados Unidos da América do Norte e teve o seu primeiro 
cultivo no Brasil em 1914, no município de Santa Rosa (RS). Na década de 1960 obteve o status de cultura econômica e a partir de 1970 se consolidou como a principal cultura do agronegócio brasileiro (Hymowitz, 1970; Urben Filho \& Souza, 1993; Câmara, 1996).

\subsubsection{Aspectos botânicos}

A soja, Glycine $\max$ (L.) Merril, é uma planta oleaginosa pertencente à família Leguminosae, subfamília Faboideae (Papilionoidea), tribo Phaseoleae, gênero Glycine L. O gênero Glycine é composto por dois subgêneros, Glycine (plantas perenes) e Soja (plantas anuais), este último contemplando a espécie G. max e sua ancestral selvagem G. soja.

Glycine max é uma espécie autógama, com flores e órgãos masculinos e femininos protegidos dentro da corola. Insetos, principalmente abelhas, podem transportar o pólen e realizar a polinização de flores de diferentes plantas, mas a taxa de fecundação cruzada, em geral, é menor que $1 \%$. As flores de soja podem apresentar coloração branca, púrpura diluída ou roxa, apresentando de 3 a 8 mm de diâmetro. O início da floração ocorre quando a planta apresenta de 10 a 12 folhas trifolioladas e botões axilares com racemos de 2 até 35 flores cada um (Carlson \& Lersten, 2004).

O sistema radicular é pivotante, constituído de um eixo principal e grande número de raízes secundárias, cujo comprimento pode atingir $1,80 \mathrm{~m}$, sendo o maior volume de raízes encontrado a $15 \mathrm{~cm}$ de profundidade. O fruto é do tipo legume e conhecido como vagem, apresenta pêlos e é formado por duas valvas de um carpelo simples que podem atingir de 2 a 7 $\mathrm{cm}$ de comprimento e alojar de 1 a 5 sementes. A vagem apresenta cor que varia entre amarelo-palha, cinza ou preta, dependendo do estágio de desenvolvimento da planta. As sementes são lisas, ovais, globosas ou elípticas e apresentam cor amarela, preta ou verde com hilo marrom, preto ou cinza (Gomes, 1990). 
A soja apresenta grande diversidade de ciclos de desenvolvimento (100-160 dias), os quais são classificados em grupos de maturação precoce, semiprecoce, médio, semitardio e tardio e, quanto ao tipo de crescimento como indeterminado, semideterminado e determinado. Fotoperíodos mais longos estimulam o desenvolvimento vegetativo, enquanto fotoperíodos mais curtos estimulam o florescimento (Sediyama, 2009; Embrapa, 2013).

Durante o ciclo vegetativo da soja são produzidos quatro tipos de folhas: cotiledonares, primárias ou simples, trifolioladas ou compostas e prófilos simples, apresentando cor verde pálida ou verde escura dependendo da cultivar. O caule é ramoso, híspido e atinge de 80 a 150 $\mathrm{cm}$. Em variedades de crescimento determinado há racemo terminal e aquelas de crescimento indeterminado o racemo é ausente (Gomes, 1990).

\subsubsection{Importância econômica}

Os grãos de soja são de grande relevância no cenário mundial de alimentos, sendo uma das principais commodities negociadas nos mercados internacionais (USDA, 2015). Segundo dados da FAOSTAT (2015), as Américas contribuem com $86 \%$ da soja produzida no mundo. Dentre os países produtores de soja, o Brasil ocupa a segunda posição com $27 \%$ dos grãos produzidos, sendo superado apenas pelos Estados Unidos da América do Norte com 35\% do total. Na safra 2013/2014 a produção brasileira foi superior a 180 milhões de toneladas de grãos (CONAB, 2014).

No Brasil, a soja é cultivada de norte a sul (Figura 2), ocupando 49\% da área plantada em grãos do país, sendo a maior parte da produção brasileira de soja oriunda dos estados Mato Grosso (MT), Paraná (PR), Rio Grande do Sul (RS) e Goiás (GO). Na RIDE, o estado de Goiás lidera com oito milhões de toneladas de grãos de soja, seguido por Minas Gerais com 3,5 e Distrito Federal (DF) com 144 mil toneladas. No DF, a principal área produtora de 
soja é o PAD-DF, o qual ostenta uma das maiores produtividades de soja do Brasil com uma média de 40 sacos/ha (CONAB, 2015).

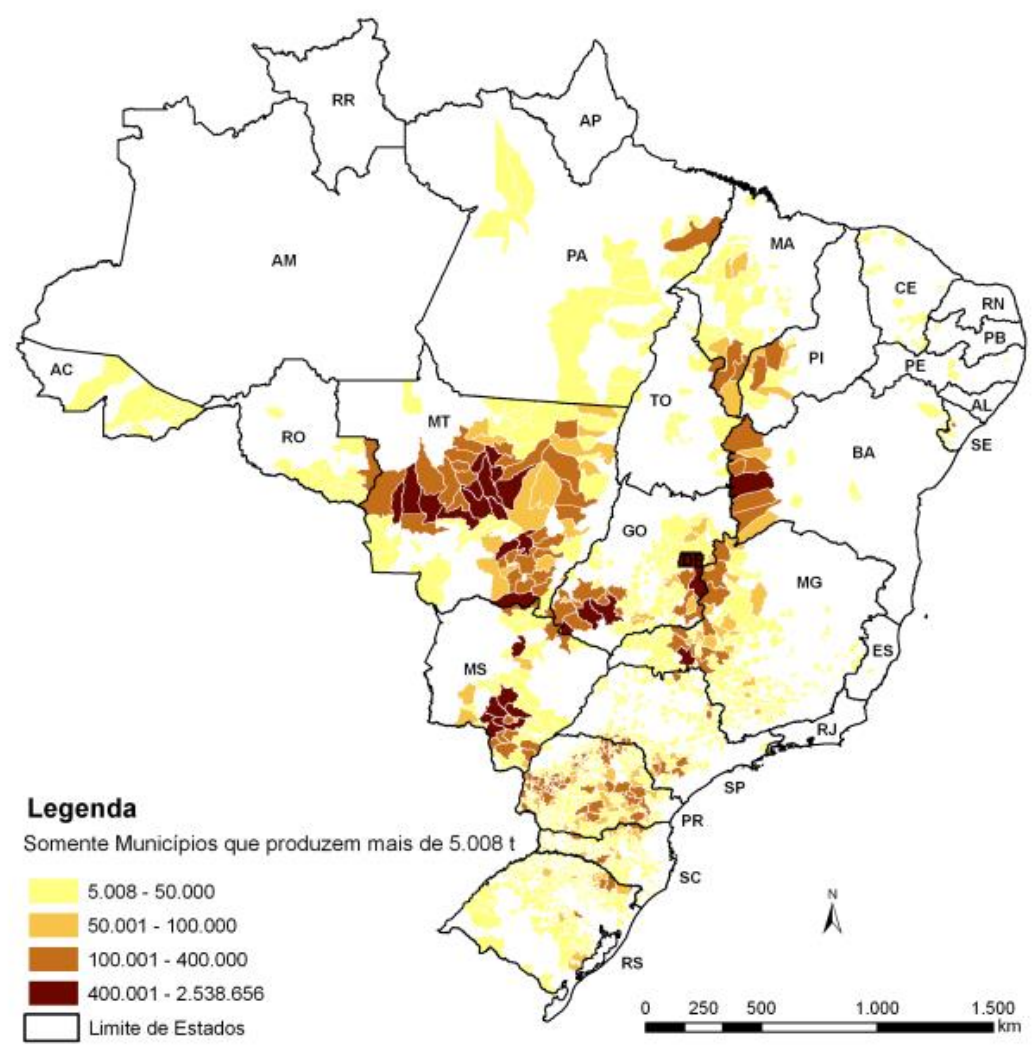

Fonte: Conab/IBGE.

Figura 2. Mapa dos estados brasileiros produtores de soja.

\subsubsection{A soja no Cerrado}

O clima em áreas de Cerrado da região Centro-Oeste é tropical, com uma estação seca e uma estação chuvosa bem definida, com amplitude térmica variando de 20 a $26^{\circ} \mathrm{C}$ e precipitação anual de 1.000 a 2.000 mm (Garrido et al., 1982; Azevedo \& Adámoli, 1988). A topografia dessa região varia entre plana a suavemente ondulada, favorecendo a agricultura mecanizada e a irrigação. O período de plantio é de outubro a dezembro. 


\subsubsection{Valor nutricional}

Os grãos de soja podem ser consumidos in natura aumentando a demanda atual por cultivares de soja para consumo humano. No entanto, cultivares de soja para consumo humano apresentam características diferentes das cultivares tradicionais de soja como a produção de sementes maiores e com teores mais elevados de proteína, ausência das enzimas lipoxigenases (AL), conferindo sabor mais suave aos alimentos a base de soja, teor reduzido do inibidor de tripsina, o que permite a redução de tratamento térmico e dos custos de processamento e tamanho, coloração e textura de sementes ideais para produção de "natto" (alimento fermentado japonês) (Carrão-Panizzi et al., 2012).

Os grãos de soja colhidos podem ser destinados à produção de óleo, farelo, extrato e misso (pasta fermentada). Da pasta fermentada se obtém o shoyu, muito utilizado na culinária oriental (Abreu et al., 2012). Já os extratos obtidos são de dois tipos: insolúveis e solúveis. Do extrato insolúvel se obtém farinha para a confecção de pães e do solúvel se obtém leite in natura ou leite em pó. O leite in natura é utilizado no fabrico do Tofu e o leite em pó no fabrico de mingaus e bebidas aromatizadas (Behrens et al., 2001).

Da extração do óleo se obtém o óleo de cozinha e a gordura hidrogenada, esta última importante componente de sorvetes e margarinas. Do óleo se extrai também duas proteínas importantes como a lecitina (entra na composição do leite em pó) e vitamina $\mathrm{E}$ (ração e medicamentos). Os resíduos da extração do óleo são conhecidos como (borra) e utilizados na produção de sabão (Hartman \& Esteves, 1989).

O farelo é utilizado na produção de ração, farinha desengordurada e farinha integral. A ração é muito utilizada na nutrição animal. Já as farinhas produzidas podem ser utilizadas na produção de carne de soja, massas, biscoitos, etc. (Morgan \& Vieira, 1996). 


\subsubsection{Estresses bióticos}

O melhoramento genético vegetal tem contribuído para o desenvolvimento de cultivares de soja com elevada produtividade, ampla adaptação e boa resistência/tolerância a fatores bióticos ou abióticos adversos. Apesar de certas cultivares apresentarem resistência a estresses bióticos, perdas de produção são constantes devido à incidência de fitopatógenos como fungos, bactérias, vírus, nematoides e insetos-pragas.

Dentre as principais pragas da soja estão: Anticarsia gemmatalis Hübner, 1818, Pseudoplusia includens Walker, (1858), (sin.: Chrysodeixis includens), Helycoverpa armigera (Hübner, 1805), Nezara viridula (Linnaeus, 1758), Piezodorus guildini (Westwood, 1837), Euschistus heros (Fabricius, 1798), Epinotia aporema (Walsingham, 1914), Sternechus subsignatus (Boheman, 1836), Spodoptera eridania (Cramer, 1782) (Embrapa, 2013).

As perdas anuais de produção por doenças na cultura da soja são estimadas em cerca de $15 \%$ a $20 \%$, entretanto, algumas doenças podem ocasionar perdas de até $100 \%$. Aproximadamente 40 doenças causadas por fungos, bactérias, nematoides e vírus já foram identificadas na cultura da soja no Brasil. Esse número continua aumentando com a expansão da cultura da soja para novas áreas e também como consequência do monocultivo. No entanto, a importância econômica de cada doença varia de ano para ano e de região para região, dependendo das condições climáticas de cada safra.

Dentre os fungos que afetam a cultura da soja no Brasil merecem destaque a ferrugem asiática (Phakopsora pachyrhizi Syd. \& P. Syd., 1914), o agente da antracnose (Colletotrichum dematium var. truncatum [Schwein.] Andrus \& W.D Moore, 1935), o agente do cancro da haste (Diaporthe phaseolorum var. meridionalis F.A. Fernández 1996), o fungo da podridão branca da haste (Sclerotinia sclerotiorum [Lib.] de Bary, 1884), o agente da podridão vermelha da raiz (Fusarium spp.) e algumas espécies de nematoides fitoparasitas. A 
expansão de áreas irrigadas nos cerrados vinha possibilitando o cultivo da soja no outono/inverno para a produção de sementes. No entanto, o cultivo de soja fora de época contribuiu para o aumento da incidência e da severidade de P. pachyrhizi (Embrapa, 2013; Almeida et al., 2005).

\subsubsection{Nematoides parasitas da cultura da soja no Brasil}

Dentre os fitopatógenos danosos à cultura da soja no Brasil, os nematoides se destacam pelos danos causados e pela dificuldade de controle. Dentre as espécies de nematoides fitoparasitas associadas à cultura da soja no Brasil, as mais impactantes são as indutoras de galhas radiculares (Meloidogyne spp.), Pratylenchus brachyurus o nematoide de cisto da soja (Heterodera glycines) e o nematoide reniforme (Rotylenchulus reniformis) (Embrapa, 2013).

O sintoma mais comum de ataque de nematoides é o nanismo de plantas que geralmente ocorre em reboleiras circulares a ovais. Os demais sintomas podem variar de acordo com o tipo de parasitismo do nematoide, determinante na relação parasita-hospedeiro, e idade e fisiologia do hospedeiro. Os sintomas em raízes envolvem desde a indução de galhas até a formação de lesões necróticas, podendo afetar raízes superficiais e profundas (Rosa et al., 2004).

\subsubsection{Meloidoginoses da soja}

Das espécies de Meloidogyne Goeldi, 1987 que afetam a cultura da soja no Brasil merecem destaque M. incognita (Kofoid \& White, 1919) e M. javanica (Treub 1885) Chitwood 1949, havendo relatos também da ocorrência de M. morocciensis Rammah \& Hirschmann, 1990 (Castro et al., 2003; Carneiro et al., 2005), M. paranaensis Carneiro et al., 1996 (Roese et al., 2004) e M. ethiopica Whitehead, 1968 (Castro et al., 2003). Meloidogyne javanica, M. incognita e M. arenaria (Neal, 1889) são as espécies mais importantes para a cultura da soja no Brasil. M. javanica tem ocorrência generalizada, enquanto $M$. incognita 
predomina em áreas cultivadas anteriormente com café ou algodão (Almeida et al., 2005; Dias, 2010). Meloidogyne enterolobii (Yang \& Eisenback, 1983), um dos principais patógenos da goiabeira na América Latina e ainda não relatado em soja é um nematoide potencialmente importante já que não tem sido encontrada fonte de resistência em germoplasma de soja contra este patógeno (Dias et al., 2010).

Os sintomas causados por Meloidogyne spp. em soja envolvem a indução de galhas terminais e intercalares em raízes, folha "carijó" (folhas com manchas cloróticas ou necroses entre as nervuras) e redução de porte das plantas infectadas (Embrapa, 2004).

O ciclo de vida de Meloidogyne spp. inicia-se com a penetração de formas préparasíticas J2 em raízes secundárias de soja. Após penetrarem, as formas J2 se tornam parasíticas e migram intercelularmente até o cilindro vascular aonde induzem a formação de sítios de alimentação conhecidos como células gigantes. Ao atingir o cilindro vascular o nematoide torna-se sedentário e passa por três ecdises (J2-J3, J3-J4 e J4-adulto). Os estádios J3 e J4 têm a forma salsichóide e o estádio adulto pode ser fêmea ou macho. A formação de fêmeas é uma constante durante o desenvolvimento da cultura. Os machos são formados em final de ciclo ou em caso de escassez de alimento. A reprodução em Meloidogyne é, em sua maioria, partenogenética mitótica, sendo assim em $M$. incognita, $M$. arenaria e $M$. javanica. Porém, existem espécies de reprodução partenogenética meiótica e anfimítica, como o que ocorre em M. hapla (Evans, 1998; Curtis et al., 2009).

A identificação correta das espécies de Meloidogyne é uma tarefa importante que objetiva auxiliar na adoção de medidas de controle específicas a cada espécie e adaptadas a cada situação (Randig et al., 2004).

\subsubsection{Heterodera glycines}

O nematoide de cisto da soja (Heterodera glycines) foi identificado pela primeira vez no Brasil no norte do Paraná, safra 1991/92 (Lima et al., 1992). Na safra 1996/97, o NCS já 
havia sido disseminado para mais de 60 municípios brasileiros dos estados do Rio Grande do Sul, Paraná, São Paulo, Goiás, Minas Gerais, Mato Grosso e Mato Grosso do Sul (Embrapa, 2004). Fatores como o trânsito de máquinas agrícolas de áreas infestadas para áreas isentas do nematoide têm contribuído para a disseminação de cistos viáveis em torrões de solo (Silva, 1998; Freitas et al., 2004).

Plantas de soja parasitadas por Heterodera glycines apresentam amarelecimento e nanismo, razão pela qual a doença é denominada nanismo amarelo da soja. Tal quadro sintomatológico é decorrente da deficiência de nitrogênio (Dhingra et al., 2009).

A cada safra, novos municípios são acrescentados à lista de municípios atingidos, representando um grande desafio para a pesquisa, a assistência técnica e o produtor brasileiro de soja (Embrapa, 2004). Atualmente, o NCS está presente em cerca de 150 municípios de dez estados (MG, MS, MT, GO, SP, PR, RS, BA, TO e MA), atingindo mais de 2.500 .000 ha de soja (Dias et al., 2004).

O NCS apresenta grande variabilidade genética (Santana et al., 2009), tendo sido detectadas no Brasil as raças 1, 2, 3, 4, 4+, 5, 6, 9, 10, 14 e 14+ (Dias et al., 2009, 2010). Campos e Silva (1997), em levantamento realizado no estado de Goiás, identificaram as raças 4, 6, 9 e 14 em Jataí, raças 3, 6 e 14 em Mineiros, raças 3 e 10 em Rio Verde e raça 14 em Perolândia e Serranópolis.

O nematoide de cisto da soja é um expoente no que diz respeito aos nematoides que causam danos à soja devido a sua facilidade de disseminação e redução da produção desta cultura. Formas J2 penetram nas raízes e migram intracelularmente até o cilindro vascular onde induzem sítios de alimentação denominados de sincícios. Durante a alimentação em células sinciciais o nematoide passa por 3 ecdises até atingir o estádio adulto, totalizando 4 ecdises (Turner \& Rowe, 2006). 
Nas populações de $H$. glycines há a formação de machos e fêmeas já que a reprodução é anfimítica. As fêmeas produzem até 500 ovos ao final de seu ciclo de vida. As fêmeas liberam parte de seus ovos em substância mucilaginosa e parte é retida em seu corpo. Quando as fêmeas morrem há a formação de cistos que apresentam parede espessa e coloração avermelhada. Os cistos podem permanecer com ovos viáveis no solo por mais de 8 anos (Moore et al., 1984).

O círculo de hospedeiras de $H$. glycines é limitado a plantas da família Leguminosae como soja (Glycine max), feijão (Phaseolus vulgaris L.), ervilha (Pisum sativum L.) e tremoço (Lupinus albus L.). A maioria das espécies cultivadas, tais como milho, sorgo, arroz, algodão, girassol, mamona, cana-de-açúcar, trigo, assim como as demais gramíneas, é resistente. O NCS não se reproduz nas plantas daninhas mais comuns nas lavouras de soja no Brasil (Ferraz \& Monteiro, 2011).

\subsubsection{Pratylenchus spp.}

O nematoide das lesões radiculares, Pratylenchus spp. contempla espécies endoparasitas migratórias amplamente disseminadas no Brasil (Dias, 2010). De acordo com Café Filho \& Huang (1988), as principais espécies de Pratylenchus encontradas na região Centro-Oeste do Brasil são $P$. brachyurus, $P$. zeae Graham (1951), $P$. coffeae Goodey (1951) e $P$. pseudopratensis Seinhorst (1968). Recentemente, Ribeiro et al. (2013) identificaram $P$. bolivianus Corbett, (1983) em soja no Centro-Oeste brasileiro por meio da comparação de sequências da região ribossomal ITS-5.8S.

Pratylenchus brachyurus é a principal espécie causadora de danos à soja no Brasil. Nos Estados Unidos da América do Norte, P. brachyurus causava perdas acima de $30 \%$ na cultura da soja no estado da Carolina do Norte (Schimitt \& Barker, 1981).

Após a eclosão dos juvenis, todos os estádios do ciclo de vida de Pratylenchus spp. são infectantes, incluindo o estádio adulto. O hábito migratório leva à formação de lesões 
necróticas no parênquima cortical o que possibilita a infecção por fungos e/ou bactérias. $\mathrm{O}$ ciclo de vida leva em torno de três semanas para ser completado e a reprodução pode ser partenogenética ou anfimítica, dependendo da espécie (Duncan \& Moens, 2006).

Alguns genótipos de soja têm fatores de redução promissores para o manejo de áreas infestadas com $P$. brachyurus (FR entre 1,2 e 3,8) que devem ser preferíveis em programas de seleção de materiais resistentes, caso sejam adaptados a uma determinada região, poderão ser utilizados em áreas infestadas (Ribeiro et al., 2007). No entanto, devido à interação de $P$. brachyurus com a soja ser menos complexa que as interações com nematoides de cisto $(H$. glycines) e de galhas (Meloidogyne spp.), não havendo necessidade de formação de nenhuma célula especializada de alimentação, a probabilidade de encontrar fontes de resistência a Pratylenchus são menores (Townshend, 1990).

\subsubsection{Rotylenchulus reniformis Linford \& Oliveira, 1940}

O algodão é a cultura mais acometida pelo nematoide $R$. reniformis. Entretanto, dependendo da cultivar e da população do nematoide no solo, também podem ocorrer danos na cultura da soja. O nematoide vem adquirindo importância na cultura da soja, em especial no Centro-sul de Mato Grosso do Sul, sendo considerado um dos principais problemas da cultura em Maracaju e Aral Moreira estando disseminado em outros dez municípios daquele estado. Na safra 2006/07, também houve relatos de danos em propriedades dos municípios de Bela Vista do Paraíso e Cornélio Procópio, no norte do Paraná (Dias, 2010).

Rotylenchulus reniformis é um nematoide de importância nos Estados Unidos da América na cultura da soja e do algodão, e cuja rotação recomendada para sua supressão juntamente a de $M$. incognita é o plantio intercalado de amendoim (Arachis hypogaea Lineu, 1753), principalmente em áreas produtoras do mesmo (Koenning et al., 2004). Em contraste com $M$. incognita, $R$. reniformis tem pouca ou nenhuma reprodução em culturas de grãos como milho ou sorgo (Robinson et al., 1997). 
Asmus (2008) relatou algumas cultivares de soja como resistentes ao nematoide reniforme, as quais tiveram performance semelhante à do padrão de resistência Custer, utilizado nos ensaios. Robbins \& Rakes (1996) notaram que, à exceção da PI88788, as fontes de resistência ao nematoide de cisto também conferiram resistência a $R$. reniformis. Asmus \& Schirmann (2004) avaliaram algumas cultivares de soja para o Estado de Mato Grosso do Sul quanto à resistência ao nematoide e concluíram que 'M-SOY 8001' e 'CD 201' apresentaram bons resultados.

O ciclo de vida deste nematoide envolve reprodução anfimítica e hábito semiendoparasita obrigatório. Dentro do ciclo de vida de $R$. reniformis apenas fêmeas jovens são infectantes, estas introduzem a parte anterior do corpo no córtex radicular e mantém a parte posterior fora da raiz. O nematoide então induz a formação de células nutridoras, as quais nutrem as fêmeas que passam a ter formato reniforme (Ferraz et al., 2010).

\subsubsection{Manejo de doenças da soja}

O controle de grande parte das doenças envolve a adoção de medidas profiláticas e o uso de cultivares resistentes. Medidas de exclusão têm sido adotadas no controle de doenças da soja como o vazio sanitário, período de 60 a 90 dias entre as estações outono e inverno sem plantas vivas de soja no campo. Neste caso a medida objetiva a redução de inóculo da ferrugem da soja Phakopsora pachyrhizi em campos de produção de soja. Outra medida de exclusão adotada é a certificação de sementes de soja. O tratamento de sementes com fungicidas também é utilizado e visa prevenir e/ou reduzir as perdas causadas por fungos e outros patógenos (Embrapa, 2015).

O controle genético envolve o plantio de cultivares resistentes, que estão disponibilizados a uma série de patógenos incluindo fungos, bactérias, vírus e nematoides. Atualmente são conhecidos vários genes de resistência, os quais agem na defesa contra 
fungos, bactérias e nematoides (Boller, 1995). O gene de maior importância atualmente é o gene Mi-1.2 que confere resistência a $M$. incognita, $M$. javanica, $M$. arenaria em tomateiro (Turner e Rowe, 2006).

O controle cultural também é utilizado e envolve o cultivo de plantas de cobertura sendo as mais comuns Crotalaria spectabilis Roth, C. grantiana Harvey, C. mucronata Desv. (1814), C. paulina Schrank (1822), mucuna preta, mucuna cinza e nabo forrageiro, as quais são principalmente utilizadas no controle de nematoides ou como adubos verdes (Embrapa, 2015). Essa prática reduz a quantidade de fitonematoides causando pouco impacto ao ambiente (Ferraz e Valle, 1995). Uma pluralidade de trabalhos realizados com plantas antagonistas concentra-se na utilização de Crotalaria spp. (crotalárias), Mucuna spp. (mucunas) e Tagetes spp. (cravos-de-defunto) (Huang \& Mota e Silva, 1980; Huang e Charchar, 1981; Weaver et al., 1993; Nogueira et al., 1997). Entretanto, para algumas gramíneas, resultados satisfatórios foram obtidos no controle de Meloidogyne spp. De acordo com Brito e Ferraz (1987) Brachiaria brizantha (Hochst ex A. Rich.) Stapf, B. decumbens Stapf. Prain, Digitaria decumbens Stent (1930) cv. Pangola, Eragrotis curvula (Schrad.) Nees e Panicum maximum Jacq cv. Guiné mostraram-se promissoras para o controle de $M$. javanica. Mais recentemente, confirmou-se a alta resistência de B. brizantha e algumas cultivares de $P$. maximum a este nematoide (Asmus e Andrade, 1997). P. maximum, B. brizantha, B. brizantha cv. MG-4 e B. decumbens foram as mais eficientes na redução de populações de M. incognita e de M. javanica (Dias-Arieria et al., 2003).

A rotação de culturas tem conferido ótimos resultados no controle do NCS com redução populacional de 70-90\% (Arantes \& Souza, 1993). Dentre as principais espécies não hospedeiras de $H$. glycines cultivadas na primavera-verão no Brasil estão o milho, o arroz, o algodão, o sorgo, o girassol e a mamona. A eclosão de juvenis de $H$. glycines é vagarosa e 
gradual, o que exige períodos de rotação de no mínimo 2 anos para o seu controle (Moore et al., 1984).

\subsection{LEVANTAMENTO DE NEMATOIDES NA CULTURA DA SOJA}

Em soja, Franzener et al. (2005) demonstraram que 19 de 21 municípios do oeste do Paraná apresentaram o nematoide de cisto (H. glycines) e $M$. javanica e $M$. incognita. Já Tubixaba tихаиа Monteiro \& Lordello, 1980, foi detectado em apenas $2 \%$ das áreas amostradas em soja. Segundo Jaehn et al. (1998) a região do Vale do Paranapanema-SP evidencia a presença de nematoides na soja como Meloidogyne spp., $P$. brachyurus e $R$. reniformis.

Silva (2007), em levantamento no município de Jataí-GO, verificou a presença de $H$. glycines, P. brachyurus, com frequência de $96,7 \%$ e $71,6 \%$ das amostras coletadas, respectivamente, e com níveis populacionais elevados.

Silva et al. (2004), em levantamento realizado no estado do Mato Grosso, verificou a presença de $P$. brachyurus em 94\% das amostras coletadas em 18 municípios e $M$. incognita em $3,7 \%$ das amostras.

De acordo com Sikora et al. (2011), em levantamento realizado no Alabama-EUA na cultura da soja em 2008 e 2009, H. glycines foi encontrada em $8 \%$ e $13 \%$ das amostras de cada ano, respectivamente.

O nematoide de cisto da soja é o nematoide que mais causa prejuízos em soja nos EUA (Creech et al., 2007). No Estado de Missouri (EUA), 49\% das áreas apresentam nematoide de cisto,tendo sido encontradas as raças 1, 2, 3, 4 e 5 (Mitchum, et al., 2005).

Na China, vale de Huang-Huai, foram relatadas as raças 1,2, 4, 5, 7, 9 e 16 de $H$. glycines, sendo $40 \%$ pertence à raça 1 e 16, 32\% à raça $4,10 \%$ às raças 2 e $7,6 \%$ à raça 5 e 2\% à raça 9 (Wei-guo, 2006). No Brasil, Roese et al. (2001) relataram $H$. glycines em 2,38\% das amostras coletadas no oeste paranaense. 


\subsection{IDENTIFICAÇÃO DE NEMATOIDES}

Os métodos tipicamente utilizados na identificação de espécies de Meloidogyne são baseados em critérios morfológicos (Hirschmann, 1985) e bioquímicos (Esbenshade \& Triantaphyllou, 1985; 1990; Blok \& Powers, 2009). Graças à técnica de amplificação de DNA por PCR, uma melhor discriminação interespecífica pode ser obtida (Power \& Harris, 1993; Petersen et al., 1997).

Abordando-se o critério da diferenciação de espécies pela morfologia, certos caracteres apresentam alta confiabilidade e aplicam-se especificamente a machos e fêmeas, como exemplo os estiletes e o padrão perineal (Hirschmann, 1985).

A técnica de eletroforese de isoenzimas com detecção de fenótipos de esterase e malatodesidrogenase tem sido a mais utilizada na identificação de $M$. arenaria, M. hapla, $M$. incognita e M. javanica (Moens et al., 2009). Mais recentemente, marcadores moleculares vêm sendo usados na amplificação por PCR de fragmentos específicos de espécies de nematoides como Meloidogyne spp., Pratylenchus spp., Heterodera spp., etc. (Moens et al., 2009).

\section{MATERIAL E MÉTODOS}

\subsection{AMOSTRAGEM}

Amostras de solo e raízes de soja foram coletadas em áreas produtoras de soja de municípios do DF e Entorno (Figura 3). Em cada município foram realizadas amostragens em propriedades rurais com suspeita de infestação por nematoides fitoparasitas (Tabela 1). O número de propriedades visitadas por município variou de uma a seis, de acordo com as indicações fornecidas por empresas da área agrícola. Cada amostra coletada por propriedade foi composta de dez subamostras coletadas em talhão com presença de reboleiras de plantas sintomáticas. Foram coletados por talhão 4 kg de solo e dez sistemas radiculares de soja. 
Tabela 1. Coordenadas geográficas de sítios de coleta de amostras nematológicas em municípios da RIDE.

\begin{tabular}{|c|c|c|}
\hline Município & Amostra & Ponto GPS \\
\hline Abadiânia-GO & 82 & S16¹3' 16,18658" ------ W4844' 44,33754" \\
\hline Abadiânia-GO & 83 & S161' 38,60192" ------ W4845' 43,89636" \\
\hline Abadiânia-GO & 84 & S16 $16^{\circ}$ '30,89554" ------ W4842' 52,38100" \\
\hline Água Fria de Goiás & 17 & S14 $47^{\prime} 40,87919^{\prime \prime}$----- W47²9'07,95237" \\
\hline Água Fria de Goiás & 35 & S1450' 18,28207" ----- W4744' 24,79924" \\
\hline Água Fria de Goiás & 36 & S144' 42,38818" ------ W4748' 49,87324" \\
\hline Água Fria de Goiás & 37 & S14³9' 58,09081" ------ W4752' 55,39846" \\
\hline Águas Lindas de Goiás-GO & 59 & S15 $42^{\prime}$ 26,23674" ----- W48 $15^{\prime}$ 12,98777" \\
\hline Águas Lindas de Goiás-GO & 60 & S1540' 43,67180" ------ W48¹5' 27,57568" \\
\hline Águas Lindas de Goiás-GO & 61 & S1540' 21,81738" ----- W48¹4' 51,06362" \\
\hline Alexânia-GO & 66 & S1557' 02,51624" ------ W48³3' 59,17991" \\
\hline Alexânia-GO & 68 & S1559' 55,89852" ------ W48³1' 44,88824" \\
\hline Alexânia-GO & 69 & S1559' 18,44187" ------ W48³4' 02,94452" \\
\hline Buritis-GO & 44 & S152 $28^{\prime} 09,36458^{\prime \prime}$------ W46 ${ }^{\circ} 54^{\prime} 43,40328^{\prime \prime}$ \\
\hline Buritis-GO & 45 & S1525' 01,59744" ------ W4652' 26,43562" \\
\hline Buritis-GO & 46 & S15 $27^{\prime} 30,12738^{\prime \prime}$----- W46 $55^{\prime}$ 22,00023" \\
\hline Cabeceiras-Goiás & 10 & S1541' 19,43573" ----- W4705' 04,36249" \\
\hline Cabeceiras-Goiás & 11 & S1540' 04,74053" ------ W4705' 04,61258" \\
\hline Cabeceiras-Goiás & 12 & S1543' 00,62249" ------ W4704' 40,42835" \\
\hline Cabeceiras-Goiás & 85 & S1545' 13,77411" ----- W4703' 08,48419" \\
\hline Cabeceiras-Goiás & 13 & S1548' 32,88865" ----- W4702' 24,88140" \\
\hline Cidade Ocidental-GO & 57 & S16 $02^{\prime} 40,58652^{\prime \prime}$------ W47045' 29,52701" \\
\hline Cidade Ocidental-GO & 58 & S1608' 15,69816" ------ W4754' 06,64792" \\
\hline Ocidental-GO & 70 & S16 $02^{\prime} 21,99248^{\prime \prime}$----- W47º6' 36,00824" \\
\hline Cocalzinho-GO & 42 & S153' 53,66223" ------ W48³5' 40,41714" \\
\hline Cocalzinho-GO & 43 & S15³9' 57,82958" ------ W48³5' 21,98060" \\
\hline Cocalzinho-GO & 81 & S1525' 28,35542" ------ W4841' 51,98422" \\
\hline Corumbá de Goiás-GO & 50 & S1557' 13,72477" ------ W4851' 40,93456" \\
\hline Corumbá de Goiás-GO & 67 & S155' 03,71590" ------ W48 $38^{\circ} 35^{\prime} 23,61603^{\prime \prime}$ \\
\hline Cristalina-GO & 27 & S16 06' 47,53234" ------ W47³4' 06,38678" \\
\hline Cristalina-GO & 28 & S16 $12^{\prime} 21,16772^{\prime \prime}$------ W47³2' 20,00480" \\
\hline Cristalina-GO & 38 & S16 04' 05,27003" ----- W47³4' 49,05663" \\
\hline Cristalina-GO & 39 & S16 $05^{\prime}$ 21,62397" ------ W47²9' 29,09468" \\
\hline Cristalina-GO & 41 & S16 $03^{\prime} 01,97898^{\prime \prime}$------ W47³2' 21,64293" \\
\hline Formosa-GO & 1 & S1542' 05,40191" ----- W47²3' 23,41984" \\
\hline Formosa-GO & 2 & S1544' 09,68911" ----- W47²6' 00,20264" \\
\hline Formosa-GO & 3 & S154' 30,70003" ------ W47023' 03,66554" \\
\hline Formosa-GO & 4 & S15³8' 12,58348" ------ W47²1' 52,56799" \\
\hline Luziânia-GO & 51 & S16 $30^{\prime} 24,52409^{\prime \prime}$------ W48 $13^{\prime} 34,82294^{\prime \prime}$ \\
\hline Luziânia-GO & 52 & S16²8' 34,77785" ------ W48¹1' 58,88954" \\
\hline Luziânia-GO & 53 & S16²4' 18,91925" ------ W48²2' 15,75162" \\
\hline Mimoso de Goiás-GO & 62 & S1505' 32,27802" ------ W48²0' 30,85599" \\
\hline Vila Boa-Goiás & 14 & S1546' 10,53064" ------ W4659' 33,86875" \\
\hline Vila Boa-Goiás & 15 & S1451' 03,87778" ----- W4642' 27,59218" \\
\hline Vila Boa-Goiás & 16 & S1506' 15,78895" ------ W4706' 47,26049" \\
\hline N. R. Jardim. Paranoá-DF & 24 & S1600' 46,74234" ------ W47¹8' 27,54666" \\
\hline PAD-DF-Paranoá & 25 & S15'59' 26,03417" ----- W47³4' 34,75537" \\
\hline PAD-DF-Paranoá & 40 & S16 01' 05,93495" ------ W47³6' 42,52142" \\
\hline Padre Bernardo-GO & 47 & S1516' 17,38822" ------ W48¹5' 59,14654" \\
\hline Padre Bernardo-GO & 48 & S1517' 30,21237" ------ W48¹8' 53,86544" \\
\hline Padre Bernardo-GO & 49 & S1517' 56,89473" ------ W48²0' 51,24433" \\
\hline Planaltina de Goiás & 22 & S1514' 57,77857" ------ W4703' 11,92245" \\
\hline Planaltina de Goiás & 23 & S1521' 42,76008" ------ W47³5' 49,35575" \\
\hline Planaltina-DF Rio Preto & 20 & S1545' 51,98578" ------ W47²5' 18,99676" \\
\hline Planaltina-DF Rio Preto & 21 & S1545' 17,96454" ------ W47²6' 52,74429" \\
\hline Planaltina-DF Rio Preto & 32 & S1546' 35,93364" ------ W47²9' 50,15039" \\
\hline Planaltina-DF Rio Preto & 33 & S1545' 09,16615" ------ W47²9' 29,52166" \\
\hline Planaltina-DF Tabatinga & 18 & S1548' 50,26936" ------ W47³3' 40,99223" \\
\hline Planaltina-DF Tabatinga & 19 & S1547' 53,55935" ----- W47³1' 52,86186" \\
\hline Planaltina-DF Tabatinga & 29 & S1552' 14,58453" ------ W47³3' 30,87674" \\
\hline Planaltina-DF Tabatinga & 30 & S1550' 37,82565" ------ W47³5' 23,99766" \\
\hline Planaltina-DF Tabatinga & 31 & S15 $49^{\prime}$ 04,93534" ------ W47º $34^{\prime}$ 47,07887" \\
\hline Planaltina-DF Tabatinga & 34 & S1545' 09,18486" ----- W47²9' 29,55515" \\
\hline Planaltina-DF Taquara. & 26 & S1540' 39,69839" ----- W47³0' 15,98188" \\
\hline Cabeceira Grande-MG & 63 & S16 $04^{\prime}$ 57,35434" ------ W47²21' 05,89222" \\
\hline Cabeceira Grande-MG & 64 & S1559' 29,42280" ----- W4704' 17,86540" \\
\hline Cabeceira Grande-MG & 65 & S16 04' 44,99955" ------ W47¹5' 40,12392" \\
\hline Unaí-MG & 54 & S16 $32^{\prime} 33,06413^{\prime \prime}$------ W4706' 32,85351" \\
\hline Unaí-MG & 55 & S16³9' 23,20553" ------ W4703' 35,00565" \\
\hline Unaí-MG & 56 & S16 $31^{\prime} 00,70766^{\prime \prime}$------ W47 $05^{\circ}$ 36,86105" \\
\hline
\end{tabular}




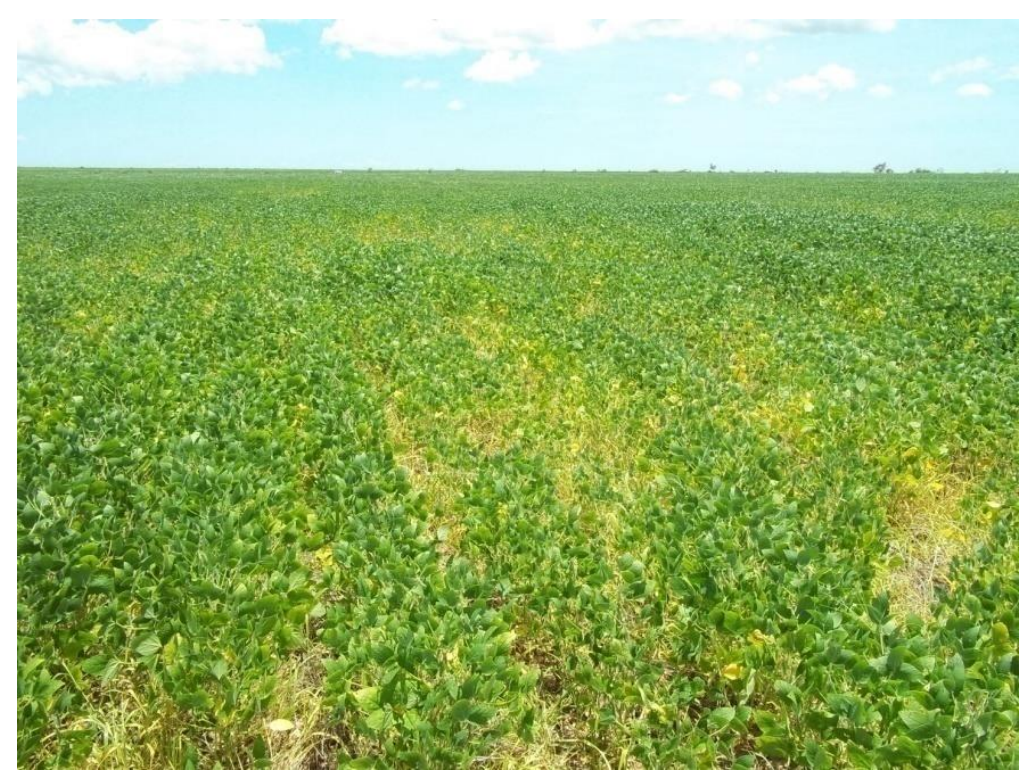

Figura 3. Lavoura de soja com enfezamento de plantas em reboleiras causado por Pratylenchus brachyurus.

A amostragem de solo compreendeu o perfil de 0-20 $\mathrm{cm}$ de profundidade. As amostras coletadas foram acondicionadas em sacos plásticos, identificadas e mantidas a $4^{\circ} \mathrm{C}$ em câmara fria até serem processadas. As áreas amostradas tiveram as coordenadas geográficas anotadas através de um GPS marca Garmin Modelo GPSMAP 76CS.

\subsection{EXTRAÇÃO DE NEMATOIDES}

Amostras de solo foram processadas no Laboratório de Nematologia da UnB, tendo-se trabalhado com alíquotas de $300 \mathrm{~cm}^{3}$ de solo. A suspensão (solo + água) foi vertida em peneiras de 45, 65 e 400 mesh. O conteúdo da peneira de 45 mesh foi descartado, o da peneira de 65 mesh foi recolhido em béquer e analisado em lupa quanto à presença de cistos de $H$. glycines, e o da peneira de 400 mesh foi submetida à metodologia de Jenkins (1964).

Os nematoides extraídos do solo foram quantificados com o auxílio de Lâmina de Peters, tendo-se realizado três leituras distintas. Após terem sido quantificados, os nematoides foram mantidos em solução de Golden (Hooper, 1986) e posteriormente infiltrados com glicerina para confecção de lâminas permanentes objetivando a identificação morfológica das 
espécies encontradas ao microscópio de luz. Pratylenchus spp. e Meloidogyne spp. foram também mantidos em solução de DESS-EDTA (Dawson et al., 1998) para posterior identificação por PCR.

\subsection{OBTENÇÃO DE POPULAÇÕES DE MELOIDOGYNE E DETERMINAÇÃO DE RAÇAS DE HETERODERA GLYCINES}

Amostras de solo oriundas de áreas infestadas com nematoides foram utilizadas como substrato para a multiplicação de populações de Meloidogyne spp. em tomateiro Santa Clara. Os vasos foram mantidos em casa de vegetação com controle de umidade, tendo sido avaliados após 60 dias de cultivo. Foi obtido um total de 10 populações de Meloidogyne spp. das doze amostras que foram inoculadas.

Seis amostras com $5 \mathrm{Kg}$ de solo contendo cistos de $H$. glycines foram enviadas a Embrapa-Soja (CNPso) em Londrina/PR, para a determinação de raças fisiológicas segundos Riggs \& Schmitt (1988) sob a supervisão do Dr. Waldir Dias. Foram utilizadas as seguintes cultivares de soja diferenciadoras: Pickett, Peking, PI 88788, PI 90763, HARTWIG, PI 437654 e Lee 74.

\subsection{EXTRAÇÃO DE OVOS E J2 DE MELOIDOGYNE SPP. EM RAÍzES DE TOMATEIRO}

A extração de ovos e $\mathrm{J} 2$ de raízes de tomateiros foi realizada de acordo com Coolen e D’Herde (1972), onde as raízes foram trituradas em liquidificador por 15 segundos em solução de hipoclorito de sódio 1,25\% e o produto passado em peneiras de 45 e 500 mesh. O material retido na peneira de 500 mesh foi recolhido em béquer e centrifugado inicialmente a 2500 rotações por minuto com $1 \mathrm{~cm}^{3}$ de caulim e logo após adição de sacarose a 1500 rotações 
por minuto. Ovos e J2 extraídos foram utilizados para extração de DNA genômico visando a identificação por PCR.

\subsection{IDENTIFICAÇÃO DE NEMATOIDES}

Nematoides pertencentes aos gêneros Pratylenchus, Helicotylenchus, Rotylenchulus e Meloidogyne foram identificados a nível de espécie, enquanto que Heterodera glycines foi identificada a nível de raça fisiológica. Os demais nematoides foram identificados a nível de gênero, tendo como referência caracteres morfológicos e morfométricos.

Para Pratylenchus spp. utilizou-se a chave de Castillo \& Vovlas (2007). Para Meloidogyne spp. utilizou-se a técnica da configuração da região perineal de fêmeas (Hartman \& Sasser, 1985), eletroforese de isoenzimas (Alonso \& Alfenas, 1998) e PCR usando-se primers específicos disponibilizados na literatura (Randing et al., 2002; Zilstra et al., 2000; Machado et al., 2007) (Tabela 2).

\subsubsection{Fenótipo isoenzimático para esterase}

As populações de Meloidogyne spp. foram multiplicadas em tomateiro e mantidas em casa de vegetação da Estação Experimental de Biologia da UnB. Fêmeas individuais foram extraídas de raízes de tomateiro e maceradas para a extração de proteínas. A maceração foi realizada em tubos de $10 \mu \mathrm{l}$ com solução extratora ( $2 \mathrm{~g}$ de sacarose, 0,2 g de Triton X-100, 1 mg de azul de bromofenol e 7,8 ml de água destilada) e auxílio de um bastão de vidro. Foram realizadas três repetições. O extrato obtido foi aplicado em gel de poliacrilamida $7,5 \%$ e submetido a uma corrente elétrica de $300 \mathrm{~mA}$ por 1 hora em um Sistema de Eletroforese Vertical LCV 10X10 Loccus-Biotecnologia. 


\subsubsection{Extração de DNA genômico e identificação de Meloidogyne por PCR}

DNA genômico foi obtido a partir de 200 a $300 \mu 1$ de ovos, de acordo com o método descrito por Randig et al. (2002). Os ovos foram macerados dentro de tubos de 0,5 $\mathrm{ml}$ com adição de nitrogênio líquido. Utilizou-se o kit Quick-gDNA Miniprep (50 preps) w/ZymoResearch IIN Columns, de acordo com as recomendações do fabricante.

\subsubsection{Reações de PCR}

Foram utilizados marcadores SCAR espécie-específicos desenvolvidos por, Zijlstra et al. (2000) e Randig et al. (2002) em quantidades equimolares na identificação de $M$. incognita, M. arenaria, M. javanica e M. hapla em reações individuais, duplex e multiplex (Tabela 2). As reações foram realizadas em volume final de $25 \mu$ contendo: $2 \mu 1$ de DNA, 0,25 $\mu \mathrm{l}$ de tampão $10 \mathrm{X} \mathrm{MgCL}_{2} ; 4 \mu \mathrm{dNTPs}[1,25 \mathrm{mM}$ ] (Invitrogen) e 0,5 $\mu \mathrm{l}$ de cada primer SCAR. Em cada tubo foi adicionada uma gota de óleo mineral para prevenção de evaporação. As amplificações foram realizadas em termociclador MJ25+ (Biocycler) na seguinte condição (Silva et al. 2014): $5 \mathrm{~min}$. a $94^{\circ} \mathrm{C} ; 35$ ciclos de 30 s a $94^{\circ} \mathrm{C}, 45$ s a $61{ }^{\circ} \mathrm{C}$, e $1 \mathrm{~min}$. a $70^{\circ} \mathrm{C}$ e extensão final de 8 min. a $70{ }^{\circ} \mathrm{C}$. Os produtos de amplificação foram separados em gel de agarose $1,2 \%$ e visualizados em luz ultravioleta, após a coloração com brometo de etídio.

Tabela 2. Características de marcadores SCAR espécie-específicos para Meloidogyne spp.

\begin{tabular}{|c|c|c|c|c|}
\hline Espécie & $\begin{array}{l}\text { Primer } \\
\text { SCAR }\end{array}$ & Sequência $\left(5^{\prime} \rightarrow 3^{\prime}\right)$ & Fragmento & Referência \\
\hline \multirow{2}{*}{ M. incognita } & Inc-K14-F & GGGATGTGTAAATGCTCCTG & \multirow{2}{*}{$399 \mathrm{pb}$} & \multirow{2}{*}{ Randig et al.(2002) } \\
\hline & Inc-K14-R & CCCGCTACACCCTCAACTTC & & \\
\hline \multirow{2}{*}{ M. arenaria } & Far & TCGGCGATAGAGGTAAATGAC & \multirow{2}{*}{$420 \mathrm{pb}$} & \multirow{2}{*}{ Zijlstra et al.(2000) } \\
\hline & Rar & TCGGCGATAGACACTACAACT & & \\
\hline \multirow{2}{*}{ M. javanica } & Fjav & GGTGCGCGATTGAACTGAGC & \multirow{2}{*}{$670 \mathrm{pb}$} & \multirow{2}{*}{ Zijlstra et al.(2000) } \\
\hline & Rjav & CAGGCCCTTCAGTGGAACTATAC & & \\
\hline \multirow{2}{*}{ M. hapla } & $\mathrm{hF}$ & TGACGGCGGTGAGTGCGA & \multirow{2}{*}{$610 \mathrm{pb}$} & \multirow{2}{*}{ Zijlstra et al.(2000) } \\
\hline & $\mathrm{hR}$ & TGACGGCGGTACCTCATAG & & \\
\hline
\end{tabular}

*pb: pares de base. 


\subsection{IDENTIFICAÇÃO DE PRATYLENCHUS SP.}

Pratylenchus sp. foi identificado por caracteres morfológicos, morfométricos, biológicos e por PCR. Os caracteres morfométricos avaliados (De Man, 1880) foram V (\% de distância entre a vulva e a região anterior em relação ao comprimento total do corpo) e $S$ (comprimento do estilete/largura do corpo na base do estilete). Os morfológicos incluíram o número de anéis labiais (1 a 3) e formato da espermateca, além da presença ou ausência de machos nas populações encontradas (biológico). Esses caracteres foram utilizados na identificação da espécie com base na análise de 30 espécimes e identificação por chave dicotômica (Castillo \& Vovlas, 2007).

A identificação por PCR foi realizada de acordo com Machado et al. (2007). Para a extração de DNA genômico utilizou-se o kit Quick-gDNA Miniprep (50 preps) w/ZymoResearch IIN Columns, de acordo com as recomendações do fabricante, a partir de 80 nematoides (adultos e juvenis) macerados com auxílio de um pistilo em almofariz com nitrogênio líquido.

O DNA obtido foi utilizado $(3 \mu \mathrm{l})$ em reações de PCR com o primer universal direto 18S 5'-TTGATTACGTCCCTGCCCTTT-3' e o primer reverso ACM7R 5'GCWCCATCCAAACAAYGAG-3'. As reações seguiram a seguinte relação temperatura /tempo: $94^{\circ} \mathrm{C}$ por 2 min. e 45 segundos e 40 ciclos a $94^{\circ} \mathrm{C}$ por 1 min., $57^{\circ} \mathrm{C}$ por 45 segundos e $72^{\circ} \mathrm{C}$ por 2 min.. A fase de extensão final foi realizada a $72^{\circ} \mathrm{C}$ por $10 \mathrm{~min}$.. As amplificações foram realizadas em termociclador MJ25+ (Biocycler).

Os produtos da amplificação por PCR foram separados em gel de agarose $1,2 \%$, corados com brometo de etídeo $(0,5 \mu \mathrm{g} / \mathrm{ml})$ e visualizados sob luz ultravioleta em transiluminador. Vinte e quatro populações de Pratylenchus foram transformadas em 8 para a extração de DNA genômico e análise por PCR. População 1 Cristalina-GO $(27,28$,) e Planaltina-DF (29, 30); população 2 Núcleo Rural Tabatinga $(31,34)$ e Núcleo Rural Rio Preto (32, 33); 
população 3 Água Fria-GO $(35,36,37)$ e Cristalina-GO (38); população 4 Cristalina-GO $(39,41)$ e Cocalzinho-GO (42); população 5 Cocalzinho-GO (43) e Buritis-MG (44, 45, 46); população 6 Padre Bernardo-GO $(47,48,49)$ e Corumbá-GO (50); população 7 (LuziâniaGO (51, 52, 53) e Unaí-MG (54); e população 8 Unaí-MG $(55,56)$ e Cidade Ocidental-GO $(58)$.

\subsection{QUANTIFICAÇÃO DE PRATYLENCHUS, DETERMINAÇÃO DO NÍVEL DE INFESTAÇÃO E PRESERVAÇÃO EM SOLUÇÃO DE DESS-EDTA}

Pratylenchus sp. foi extraído de amostras de $300 \mathrm{cc}$ de solo como no item 4.2. Os nematoides encontrados foram quantificados em microscópio óptico com auxílio de lâmina de Peters. O nível de infestação para cada área foi estimado com base na seguinte classificação: Baixo, quando detectados até 100 nematoides por 300 cc de solo; Médio, com 101-400 nematoides/300 cc de solo; Alto, com mais 400 nematoides/300 cc de solo (Koenning et al., 2015). Os nematoides encontrados foram mortos a $53{ }^{\circ} \mathrm{C} / 1 \mathrm{~min}$. e transferidos para tubos de 0,5 ml contendo solução DESS-EDTA com auxílio de um estilete e para recipientes com solução de Golden.

\subsection{FIXAÇÃO DE NEMATOIDESE PARA MICROSCOPIA ELETRÔNICA DE VARREDURA}

Para a identificação de Pratylenchus brachyurus, também foi utilizada a técnica de microscopia eletrônica de varredura (MEV). As amostras foram fixadas em uma solução aquosa de glutaraldeído a $2 \%$ e paraformaldeído a 2\%. Após a fixação, o material foi preservado em uma solução tampão de cacodilato de sódio a 0,1M, aguardando o processo de pós-fixação, onde o material foi submerso em uma solução de tetróxido de ósmio a 1\%. Em seguida, o material passou por um processo de desidratação gradativa com banhos de soluções 
aquosas de acetona de 30,50, 70 e $90 \%$ e três banhos de acetona pura, de 15 minutos cada, antes de sofrer a secagem ao ponto crítico com $\mathrm{CO} 2$ e metalização de sua superfície em um sputter coater. O material foi fotografado no microscópio Jeol (JSM-70001F).

\section{RESULTADOS}

\subsection{IDENTIFICAÇÃO E QUANTIFICAÇÃO DE PRATYLENCHUS}

Na RIDE, $P$. brachyurus foi encontrado parasitando raízes de soja e causando necroses e redução na altura das plantas. Foram detectadas 68 populações de $P$. brachyurus em municípios da RIDE. Dessas populações, 48 foram coletadas em 16 municípios do Estado de Goiás, 6 populações nos municípios de Unaí e Cabeceira Grande e 14 populações no Distrito Federal envolvendo as regiões administrativas de Planaltina, Paranoá e Núcleo Rural do Rio Preto (Tabela 3).

Nas amostras de solo coletadas na RIDE, 70,5\% apresentaram níveis populacionais baixos para $P$. brachyurus, enquanto $28 \%$ apresentaram níveis médios e apenas uma localidade (1,5\%) no município de Água Fria de Goiás apresentou nível alto.

Os valores de $P$. brachyurus por grama de raiz variaram entre as amostras coletadas. Para 11,7\% variou de 33 a 72 e média de 48,7 nematoides/g de raiz, permanecendo o restante das amostras (88,23\%) com variação de 1 a 29 e média de 6,86 nematoides/g de raiz (Tabela 4).

Das populações encontradas, espécimes representativos de 24 populações foram mantidos em solução de DESS-EDTA para análise por PCR e espécimes das 68 populações foram mantidas em solução Golden, infiltração com glicerina e montagem de lâminas permanentes para análise morfológica e morfométrica. 
Nas populações encontradas apenas fêmeas foram detectadas com valores de $\mathrm{V}$ variando de 83,6 a $87,05 \%$, comprimento do estilete variando de 18,75-22,5 e valores médios de $\mathrm{S}$ variando de 1,15 (1,05 a 1,28), saco pós uterino curto, além da presença de 2 anéis labiais, região cefálica destacada do corpo e ausência de espermateca funcional, cauda conóide de ponta lisa (Erro! Fonte de referência não encontrada., Figura 5 e Figura 6).

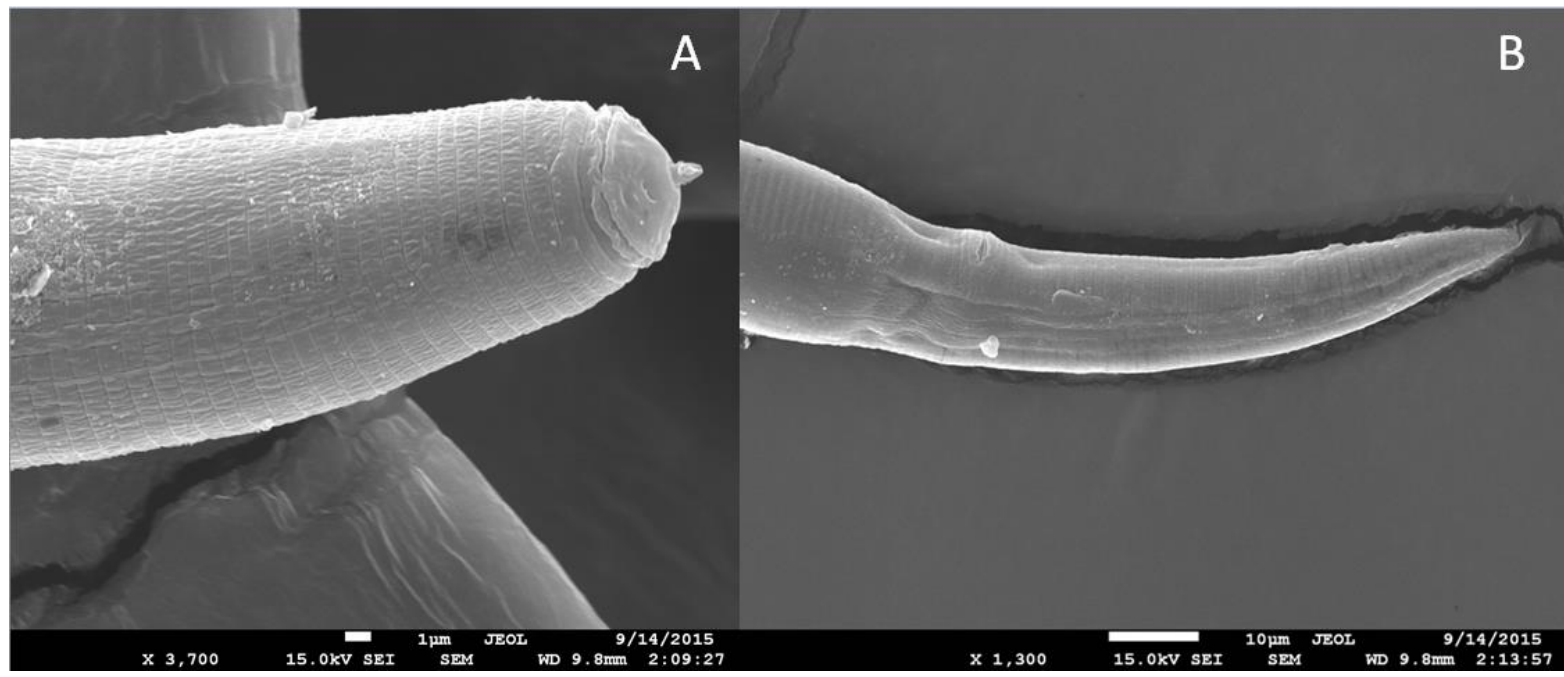

Figura 4. Micrografias ao microscópio eletrônico de varredura com vista lateral da região cefálica (A) e da cauda (B) de Pratylenchus brachyurus.

A identificação morfológica seguiu a chave dicotômica proposta por Castillo \& Vovlas (2007) assim como a proposta por Café Filho \& Huang (1988) e sugere P. brachyurus como a espécie presente nas 68 populações encontradas. O marcador molecular desenvolvido por Machado et al. (2007) foi utilizado em reações de PCR e amplificou um único fragmento de DNA genômico de 267 pb com base no DNA genômico de amostras oriundas do DF e dos estados de Goiás e MG. 


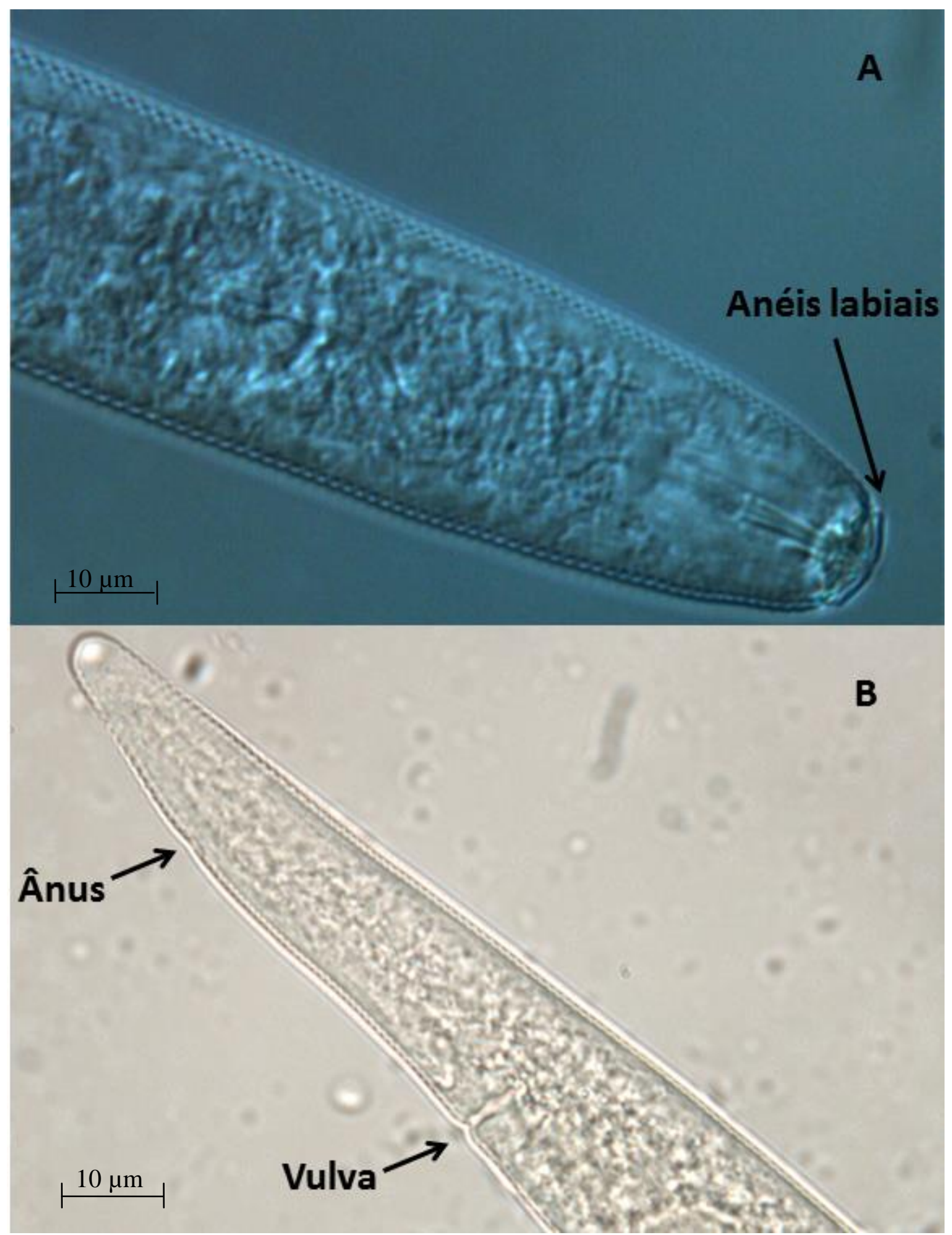

Figura 5. Micrografias ao microscópio Óptico de Pratylenchus brachyurus. A- região anterior; B- região Posterior mostrando a vulva, ânus e cauda conóide. 


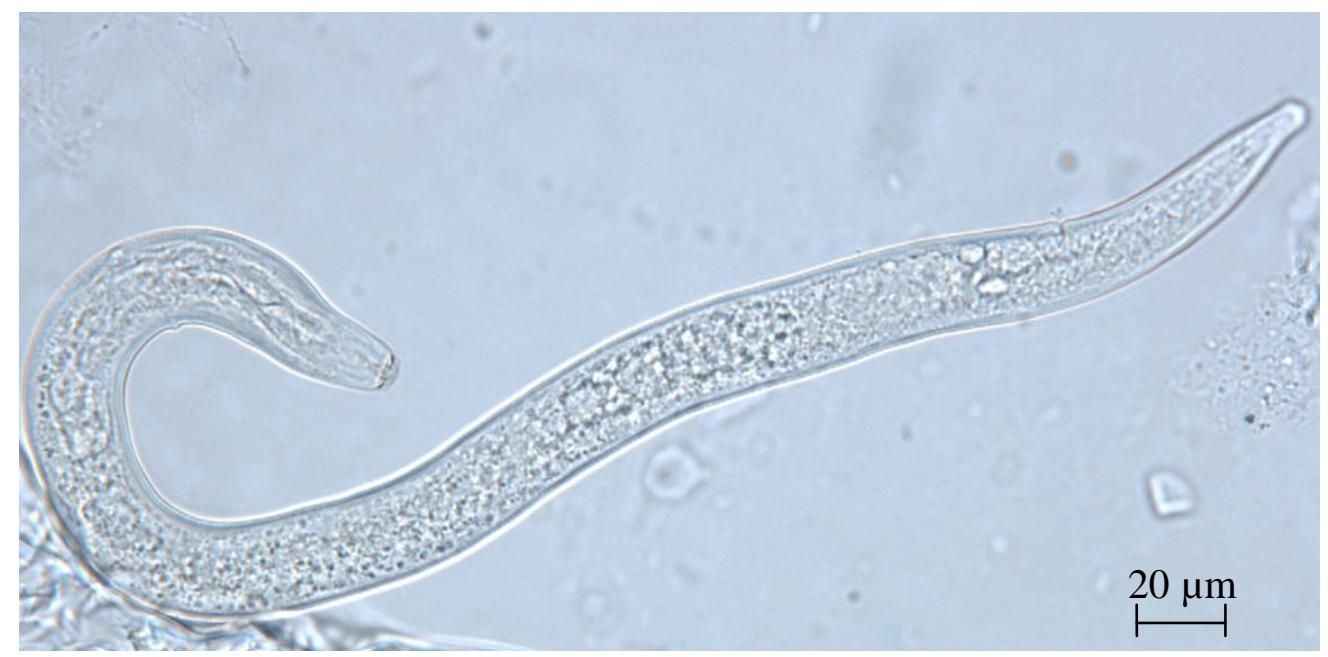

Figura 6. Fêmea de Pratylenchus brachyurus.

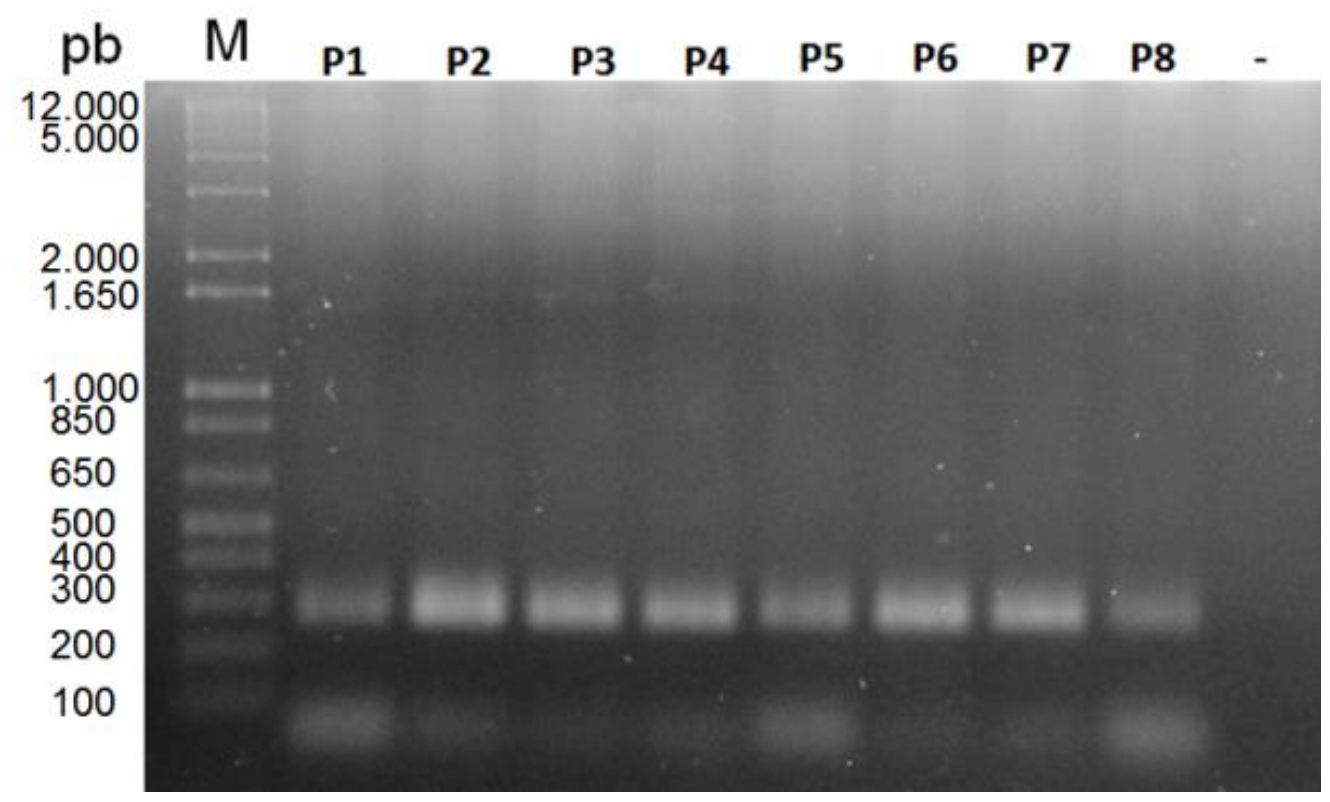

Figura 7. Gel de agarose da amplificação por PCR de fragmentos de DNA genômico de 267 pb referentes a 8 populações de Pratylenchus brachyurus (P1 a P8) coletadas na RIDE. $\mathrm{M}=$ marcador molecular $1 \mathrm{~Kb}$ Plus DNA Ladder. 
Tabela 3. Nível populacional em amostras de 300 cc de solo de Pratylenchus brachyurus em municípios da RIDE-DF.

\begin{tabular}{|c|c|c|c|c|c|c|c|}
\hline Municípios/Estado & Amostra & Nematoides & $\begin{array}{c}\text { Nível de } \\
\text { Infestação }\end{array}$ & Municípios/Estado & Amostra & Nematoides & $\begin{array}{c}\text { Nível de } \\
\text { Infestação }\end{array}$ \\
\hline \multirow{3}{*}{ Abadiânia-GO } & 82 & 14 & Baixo & \multirow{4}{*}{ Formosa-GO } & 1 & 13 & Baixo \\
\hline & 83 & 0 & Baixo & & 2 & 0 & Baixo \\
\hline & 84 & 0 & Baixo & & 3 & 372 & Médio \\
\hline \multirow{4}{*}{ Água Fria de Goiás-GO } & 17 & 525 & Alto & & 4 & 0 & Baixo \\
\hline & 35 & 388 & Médio & \multirow{3}{*}{ Luziânia-GO } & 51 & 44 & Baixo \\
\hline & 36 & 75 & Baixo & & 52 & 90 & Baixo \\
\hline & 37 & 168 & Médio & & 53 & 60 & Baixo \\
\hline \multirow{3}{*}{ Águas Lindas de Goiás-GO } & 59 & 85 & Baixo & Mimoso-GO & 62 & 0 & Baixo \\
\hline & 60 & 14 & Baixo & \multirow{3}{*}{ Padre Bernardo-GO } & 47 & 182 & Médio \\
\hline & 61 & 28 & Baixo & & 48 & 50 & Baixo \\
\hline \multirow{3}{*}{ Alexânia-GO } & 66 & 140 & Médio & & 49 & 46 & Baixo \\
\hline & 68 & 336 & Médio & \multirow{3}{*}{ Vila Boa-GO } & 14 & 0 & Baixo \\
\hline & 69 & 50 & Baixo & & 15 & 21 & Baixo \\
\hline \multirow{3}{*}{ Buritis-GO } & 44 & 231 & Médio & & 16 & 0 & Baixo \\
\hline & 45 & 225 & Médio & \multirow{2}{*}{ Planaltina de Goiás-GO } & 22 & 90 & Baixo \\
\hline & 46 & 52 & Baixo & & 23 & 104 & Médio \\
\hline \multirow{5}{*}{ Cabeceiras-GO } & 10 & 0 & Baixo & \multirow{2}{*}{ PAD-DF Paranoá } & 25 & 83 & Baixo \\
\hline & 11 & 20 & Baixo & & 40 & 88 & Baixo \\
\hline & 12 & 0 & Baixo & N. R. Jardim Paranoá-DF & 24 & 147 & Médio \\
\hline & 85 & 0 & Baixo & \multirow{6}{*}{ N.R. Tabatinga Planaltina-DF } & 18 & 16 & Baixo \\
\hline & 13 & 0 & Baixo & & 19 & 0 & Baixo \\
\hline \multirow{3}{*}{ Cidade Ocidental } & 57 & 60 & Baixo & & 29 & 39 & Baixo \\
\hline & 58 & 304 & Médio & & 30 & 120 & Médio \\
\hline & 70 & 85 & Baixo & & 31 & 72 & Baixo \\
\hline \multirow{3}{*}{ Cocalzinho-GO } & 42 & 32 & Baixo & & 34 & 50 & Baixo \\
\hline & 43 & 180 & Médio & \multirow[t]{2}{*}{ N.R. Taquara-DF } & 26 & 126 & Médio \\
\hline & 81 & 42 & Baixo & & 20 & 44 & Baixo \\
\hline \multirow{2}{*}{ Corumbá de Goiás-GO } & 50 & 0 & Baixo & \multirow{3}{*}{ N.R Rio Preto-DF } & 21 & 0 & Baixo \\
\hline & 67 & 13 & Baixo & & 32 & 11 & Baixo \\
\hline \multirow{7}{*}{ Cristalina-GO } & 27 & 51 & Baixo & & 33 & 38 & Baixo \\
\hline & 28 & 90 & Baixo & \multirow{3}{*}{ Cabeceira Grande-MG } & 63 & 105 & Médio \\
\hline & 38 & 0 & Baixo & & 64 & 42 & Baixo \\
\hline & 39 & 0 & Baixo & & 65 & 360 & Médio \\
\hline & 41 & 105 & Médio & \multirow{3}{*}{ Unaí-MG } & 54 & 136 & Médio \\
\hline & & & & & 55 & 176 & Médio \\
\hline & & & & & 56 & 340 & Médio \\
\hline
\end{tabular}

Nível de infestação baixo= até 100 nematoides; médio=101-400 nematoides; e alto: acima de 400 nematoides. 
Tabela 4. Nematoides extraídos de raízes de soja coletadas em propriedades rurais da RIDE.

\begin{tabular}{|c|c|c|c|c|c|c|c|c|c|}
\hline Amostra & Het. & Helicot. & Prat. & Mel. & Amostra & Het. & Helicot. & Prat. & Mel. \\
\hline 1 & - & 6 & 1 & - & 40 & - & - & 6 & - \\
\hline 2 & - & 2 & 29 & - & 41 & - & 2 & 10 & - \\
\hline 3 & - & 15 & 2 & 0 & 42 & - & 1 & 0 & - \\
\hline 4 & - & 24 & 22 & - & 43 & - & 5 & 4 & - \\
\hline 10 & - & 7 & 4 & 3 & 44 & - & 6 & 42 & - \\
\hline 11 & - & 0 & 5 & 0 & 45 & - & 15 & 72 & 25 \\
\hline 12 & - & - & 2 & 0 & 46 & - & 10 & 6 & - \\
\hline 85 & - & - & 4 & - & 47 & - & - & 12 & - \\
\hline 13 & - & 13 & 6 & 1 & 48 & - & 5 & 7 & - \\
\hline 14 & - & 6 & 4 & 1 & 49 & - & - & 1 & - \\
\hline 15 & - & - & 1 & 1 & 50 & - & 1 & 4 & - \\
\hline 16 & - & - & - & - & 51 & - & 1 & 7 & - \\
\hline 17 & - & - & 18 & 34 & 52 & - & 1 & 12 & - \\
\hline 18 & - & 4 & 3 & - & 53 & 1 & 1 & 4 & - \\
\hline 19 & - & 2 & 1 & 143 & 54 & - & 4 & 13 & - \\
\hline 20 & - & 3 & 2 & 3 & 55 & - & 7 & 35 & - \\
\hline 21 & - & 2 & 4 & - & 56 & - & 1 & 18 & - \\
\hline 22 & - & 4 & 12 & 96 & 57 & - & 1 & 2 & - \\
\hline 23 & - & 1 & 2 & 0 & 58 & - & 6 & 17 & - \\
\hline 24 & - & 2 & 25 & - & 59 & - & 1 & 6 & - \\
\hline 25 & - & 5 & 25 & - & 60 & - & 16 & 36 & - \\
\hline 26 & - & 6 & 66 & - & 61 & - & 7 & 33 & - \\
\hline 27 & 1 & 3 & 3 & - & 62 & - & - & 0 & - \\
\hline 28 & - & 13 & 4 & - & 63 & - & 3 & 34 & 4 \\
\hline 29 & 1 & 1 & 2 & - & 64 & - & 1 & 1 & - \\
\hline 30 & - & 1 & 19 & - & 65 & - & 1 & 3 & - \\
\hline 31 & - & 9 & 13 & - & 66 & - & 1 & 2 & - \\
\hline 32 & - & 5 & 1 & - & 67 & - & - & 1 & - \\
\hline 33 & - & 10 & 4 & - & 68 & - & - & 2 & - \\
\hline 34 & - & 11 & 16 & - & 69 & - & - & 1 & - \\
\hline 35 & - & 10 & 8 & - & 70 & - & 1 & 72 & - \\
\hline 36 & - & 8 & 2 & - & 81 & - & 1 & 1 & - \\
\hline 37 & - & 2 & 1 & - & 82 & - & 2 & 11 & - \\
\hline 38 & - & - & 10 & - & 83 & - & - & 2 & - \\
\hline 39 & - & - & 5 & - & 84 & - & 5 & 3 & - \\
\hline
\end{tabular}

Legenda: Het.=Heteroder $;$ Helicot= Helicotylenchus; Prat.=Pratylenchus; Mel.=Meloidogyne . Obs.: os resultados foram baseados no peso de raízes inteiras e dados em nematoides/grama de raiz. 


\subsection{IDENTIFICAÇÃO E QUANTIFICAÇÃO DE MELOIDOGYNE SPP.}

Meloidogyne arenaria, M. incognita e $M$. javanica foram detectados parasitando soja em municípios da RIDE. A identificação de $M$. javanica e $M$. arenaria foi realizada com base em fenótipos de esterase e/ou amplificação por PCR conforme as Figura 8, Figura 9Figura 10Figura 11 e descrito na Tabela 5.

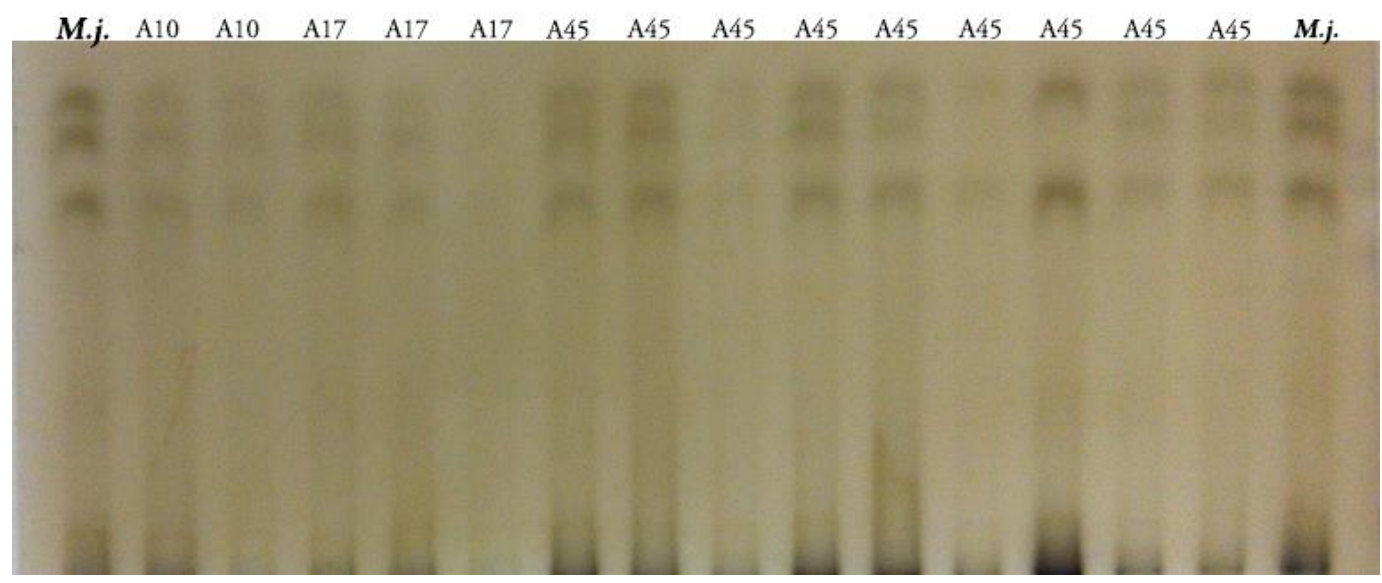

Figura 8. Fenótipo de esterase (J3) em populações de Meloidogyne javanica coletadas na RIDE. 


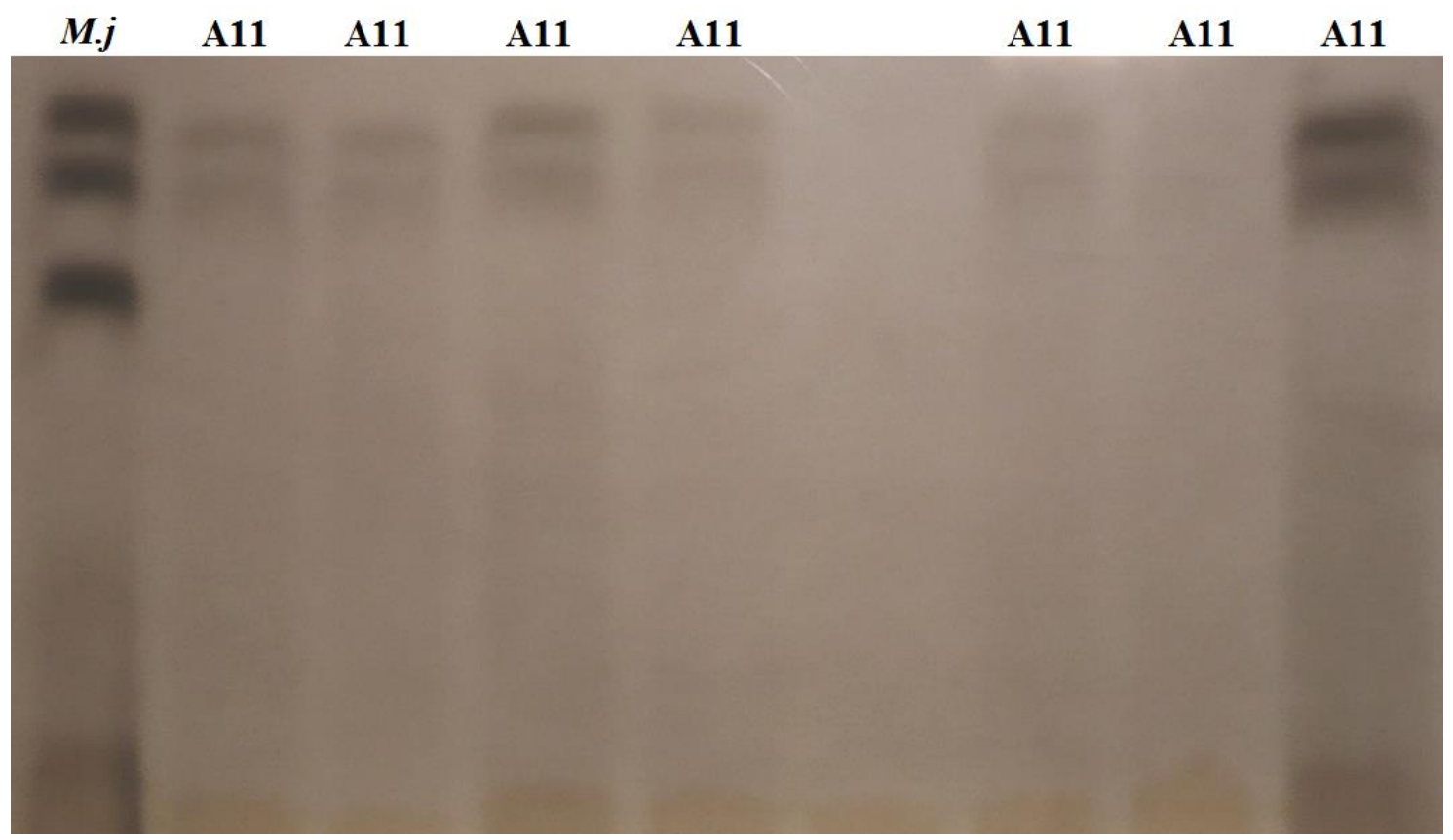

Figura 9. Gel de poliacrilamida com fenótipo Esterase A2 detectado a partir de fêmeas individuais extraídas de raiz de tomateiro (amostra A11).

Populações de $M$. javanica e $M$. arenaria foram identificadas mediante a detecção de fragmentos de 670 e 420 pb, respectivamente, de acordo com Zijlstra et al., (2000) (Figura 10 eFigura 11). As populações 10, 19 e 45 de $M$. arenaria não tiveram o fenótipo de esterase revelado, tendo sido identificadas apenas por PCR (420 pb) (Tabela 5). No entanto, estas três populações necessitam de confirmação uma vez que o marcador molecular para $M$. arenaria amplifica um fragmento de DNA de mesmo tamanho para M. morocciensis.

Os fenótipos de esterase identificados foram J3 para M. javanica e A2 para M. arenaria. Não foi detectado fenótipo de esterase para M. incognita nas amostras 13 e 22. No entanto, esta espécie foi confirmada por PCR, fragmento de $399 \mathrm{pb}$, mediante o uso de marcador molecular específico. 


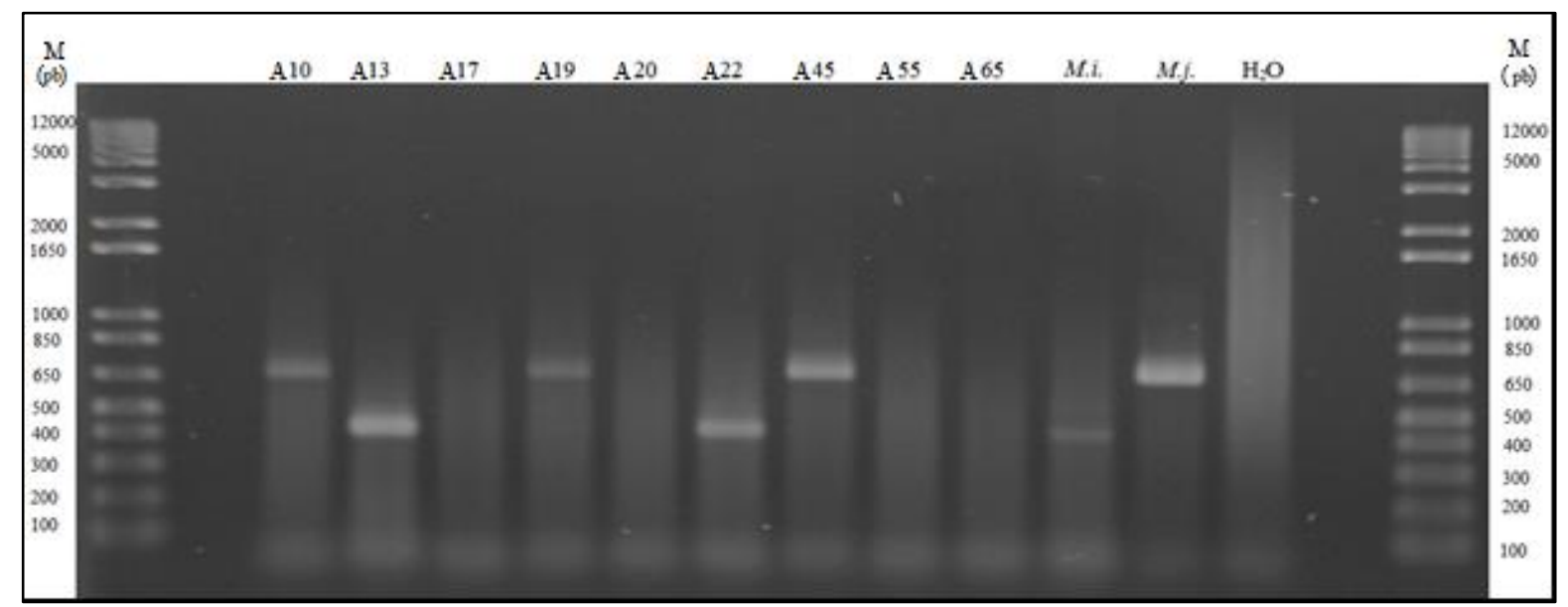

Figura 10. PCR com primers específicos para Meloidogyne incognita e M. javanica. $\mathrm{M}=1$ Kb Plus DNA Ladder; $\mathrm{pb}=$ pares de base; $\mathrm{A}=$ amostra.

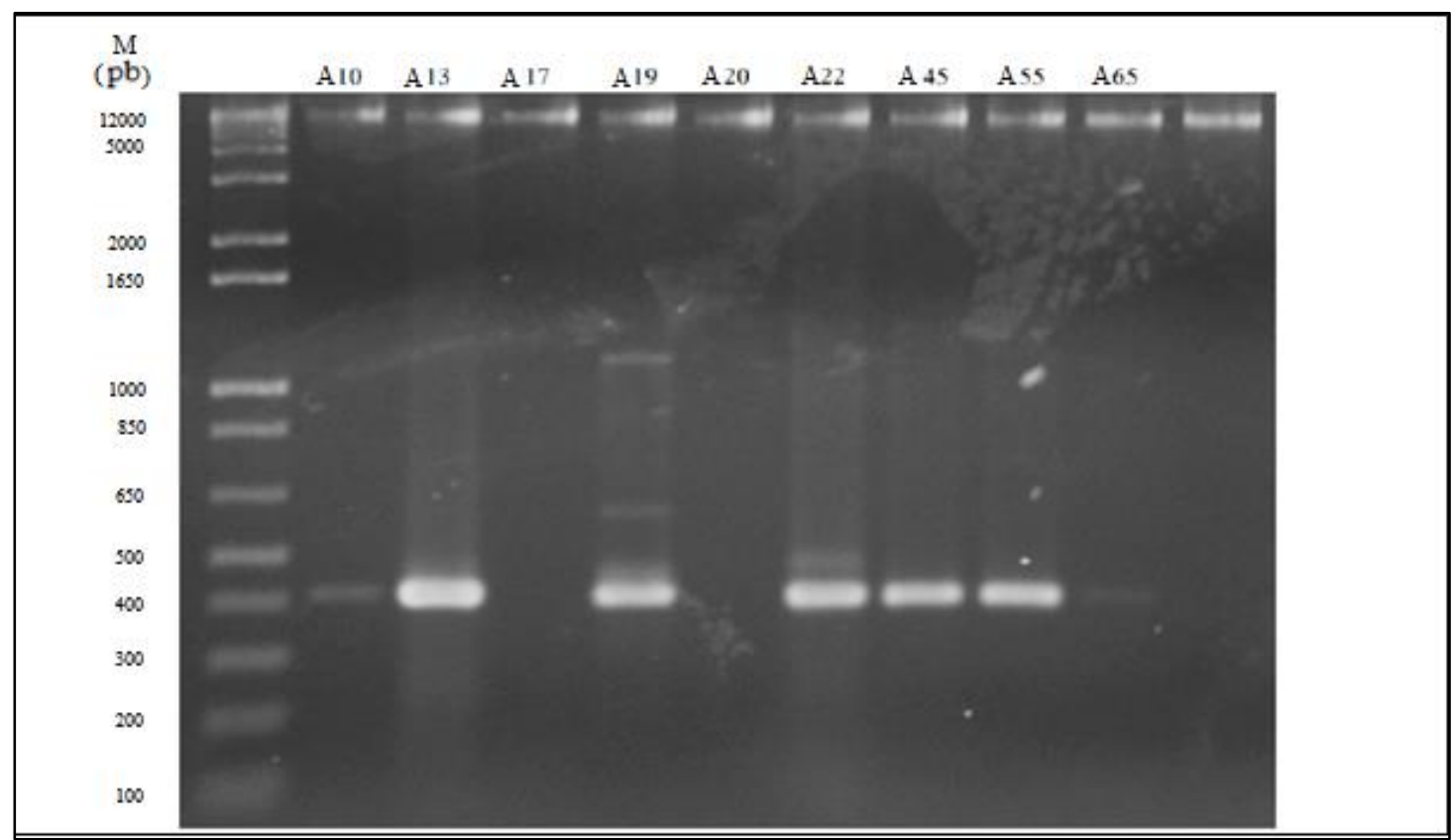

Figura 11. PCR com primers específicos para Meloidogyne arenaria e M. hapla.

$\mathrm{M}=1 \mathrm{~Kb}$ Plus DNA Ladder; $\mathrm{pb}=$ pares de base; $\mathrm{A}=$ amostra.

A presença de formas $\mathrm{J} 2$ de Meloidogyne variou nas amostras de solo coletadas. Foi detectado um máximo de $3.180 \mathrm{~J} 2 / 300 \mathrm{cc}$ de solo, havendo amostras com 20 nematoides e também com galhas em raízes e ausência de $\mathrm{J} 2$ na amostra de solo. $\mathrm{O}$ número de $\mathrm{J} 2 / \mathrm{g}$ de raiz também variou, tendo sido encontrado um máximo de 143 nematoides/g de raiz e ausência de nematoides em amostras de raízes (

Tabela 5). 
Tabela 5. Quantificação e identificação de populações de Meloidogyne spp. coletadas na RIDE.

\begin{tabular}{|c|c|c|c|c|c|c|}
\hline Município/Estado & Amostra & Espécie(s) & Esterase & Fragmento (pb) & $\begin{array}{c}\mathrm{J} 2 / 300 \text { cc de } \\
\text { solo }\end{array}$ & $\begin{array}{l}\mathrm{J} 2 / \mathrm{g} \\
\text { raiz }\end{array}$ \\
\hline \multirow[t]{2}{*}{ Água Fria de Goiás (GO) } & \multirow[t]{2}{*}{17} & M. javanica & $\mathrm{J} 3$ & --- & \multirow[t]{2}{*}{555} & \multirow[t]{2}{*}{34} \\
\hline & & M. arenaria & A2 & --- & & \\
\hline $\begin{array}{l}\text { Águas Lindas de } \\
\text { Goiás/GO }\end{array}$ & 60 & --- & --- & --- & 28 & 0 \\
\hline \multirow{2}{*}{ Buritis/GO } & \multirow{2}{*}{45} & M. javanica & J3 & 670 & \multirow{2}{*}{1300} & \multirow{2}{*}{25} \\
\hline & & M. arenaria & --- & 420 & & \\
\hline \multirow{2}{*}{ Cabeceira Grande/MG } & \multirow[b]{2}{*}{65} & M. arenaria & $\mathrm{A} 2$ & 420 & \multirow{2}{*}{3180} & \multirow{2}{*}{0} \\
\hline & & M. javanica & $\mathrm{J} 3$ & --- & & \\
\hline \multirow{4}{*}{ Cabeceiras/GO } & 10 & $\begin{array}{l}\text { M. javanica } \\
\text { M. arenaria }\end{array}$ & $\begin{array}{l}\text { J3 } \\
---\end{array}$ & $\begin{array}{l}670 \\
420\end{array}$ & 119 & \multirow[t]{2}{*}{3} \\
\hline & 11 & M. arenaria & $\mathrm{A} 2$ & --- & 20 & \\
\hline & \multirow{2}{*}{13} & M. incognita & --- & 399 & \multirow{2}{*}{0} & \multirow{2}{*}{1} \\
\hline & & M. arenaria & $\mathrm{A} 2$ & 420 & & \\
\hline \multirow{2}{*}{ Planaltina de Goiás/GO } & \multirow{2}{*}{22} & M. incognita & --- & 399 & \multirow{2}{*}{120} & \multirow{2}{*}{96} \\
\hline & & M. arenaria & $\mathrm{A} 2$ & 420 & & \\
\hline \multirow{2}{*}{ Planaltina-Tabatinga/DF } & \multirow{2}{*}{19} & M. javanica & $\mathrm{J} 3$ & 670 & \multirow{2}{*}{840} & \multirow{2}{*}{143} \\
\hline & & M. arenaria & --- & 420 & & \\
\hline \multirow{2}{*}{ Planaltina-Rio Preto/DF } & 20 & M. arenaria & A2 & --- & 0 & 3 \\
\hline & 32 & M. javanica & $\mathrm{J} 3$ & --- & 0 & 0 \\
\hline Unaí/MG & 55 & M. arenaria & A2 & 420 & 60 & 0 \\
\hline
\end{tabular}

$\mathrm{pb}=$ Pares de base 


\subsection{QUANTIFICAÇÃO DE CISTOS E J2 DE HETERODERA GLYCINES E DETERMINAÇÃO DE RAÇA FISIOLÓGICA}

Em amostras de solo, o nematoide $H$. glycines foi detectado em nove áreas produtoras de soja da RIDE referentes aos municípios de Cabeceira Grande - MG (1), Cabeceiras - GO (1), Cristalina - GO (4), Planaltina - Tabatinga - DF (1), PAD-DF (1) e Luziânia - GO (1) (Tabela 6). O número de cistos viáveis variou de 3 a 1060 por 300cc de solo e o de cistos totais de 5 a 1620. Nas amostras de solo, houve grande variação no número de J2, com um máximo de 1400 em Cabeceira Grande (MG) e ausência de J2 na amostra de Cabeceiras (GO).

Tabela 6. Cistos e $\mathrm{J} 2$ de Heterodera glycines detectados em amostras de $300 \mathrm{cc}$ de solo em municípios da RIDE.

\begin{tabular}{cccccc}
\hline Município/Estado & $\begin{array}{c}\text { Amostra(s) } \\
\mathbf{N}^{\mathbf{0}}\end{array}$ & $\begin{array}{c}\text { Cistos } \\
\text { inviáveis }\end{array}$ & $\begin{array}{c}\text { Cistos } \\
\text { viáveis }\end{array}$ & $\begin{array}{c}\text { Cistos } \\
\text { totais }\end{array}$ & J2 \\
\hline Cabeceiras (GO) & 12 & 5 & 3 & 8 & 0 \\
& 27 & 24 & 96 & 120 & 170 \\
Cristalina (GO) & 38 & 108 & 103 & 211 & 216 \\
& 39 & 10 & 3 & 13 & 26 \\
Planaltina (DF) & 29 & 3 & 2 & 5 & 21 \\
PAD-DF & 40 & 11 & 30 & 41 & 78 \\
Luziânia (GO) & 51 & 196 & 124 & 246 & 292 \\
Cab. Grande (MG) & 64 & 560 & 1.060 & 1.620 & 1400 \\
Unaí (MG) & 56 & 0 & 0 & 0 & 20 \\
\hline
\end{tabular}


A reação em plantas hospedeiro-diferenciadoras detectou a presença da raça 3 nas amostras analisadas com infecção apenas da cultivar Lee 74, segundo o esquema de diferenciação de raças de H. glycines proposto por Riggs \& Schmitt (1988) (Tabela 7).

Tabela 7. Determinação de raças de Heterodera glycines em municípios da RIDE.

\begin{tabular}{ccccc}
\hline Amostra(s) & $\mathbf{N}^{\mathbf{0}}$ de ovos & Lee 74 & IF (\%) & Raça \\
\hline Cristalina & 3000 & 55,5 & 100 & 3 \\
PAD-DF e Planaltina & 4000 & 129,3 & 100 & 3 \\
Luziânia & 1500 & 46,8 & 100 & 3 \\
Cabeceira Grande e & 1500 & 33,0 & 100 & 3 \\
Unaí & & & &
\end{tabular}

Legenda: $\mathrm{IF}=$ índice de fêmeas

\subsection{OUTROS NEMATOIDES FITOPARASITAS}

Outros nematoides fitoparasitas associados à soja na RIDE foram identificados a nível de gênero. Foram encontrados Helicotylenchus, Criconemoides, Trichodorus e Tylenchorhynchus. Em amostras de solo (300 cc), Helicotylenchus spp. foi encontrado em todas as áreas produtoras de soja da RIDE com um mínimo de 18 e um máximo de 3420 nematoides/300cc de solo, este último na amostra 31 coletada em Planaltina-Tabatinga(DF), ocorrendo em população mista com $P$. brachyurus. Em raízes de soja, Helicotylenchus sp. variou de 1 a 72 nematoides/g de raiz (Tabela 8).

Criconemoides spp. foi encontrado na amostra 3 (Formosa - GO) e amostra 11 (Cabeceiras - GO), com 12 e 20 nematoides/300 cc de solo, respectivamente. Na amostra 3 esse nematoide foi detectado com $P$. brachyurus e Helicotylenchus spp. e na amostra 11 juntamente com P. brachyurus, M. arenaria e Helicotylenchus spp. (Tabela 8).

O nematoide $R$. reniformis foi detectado em uma amostra de solo do núcleo rural Tabatinga, localizado na região administrativa de Planaltina-DF. Foram detectados 133 
espécimes/300 cc de solo. Fêmeas do nematoide foram encontradas no solo, mas não quantificadas (Tabela 9).

Trichodorus sp. foi encontrado nas amostras anteriores (3 e 11), 29 e 30 (PlanaltinaTabatinga), 36 e 37 (Água Fria de Goías) e 66 (Alexânia - GO). O nível populacional em campo variou de 12 a 108 nematoides/300 cc de solo, sendo que o maior nível populacional ocorreu na amostra 37 coletada em Água Fria de Goiás. Na amostra 29, Trichodorus spp. foi encontrado juntamente com $H$. glycines e P. brachyurus e nas amostras 30, 36, 37 e 66 juntamente com Helicotylenchus e P. brachyurus.

Foram encontrados também nematoides micófagos (Aphelenchus e Aphelenchoides), bacteriófagos (Acrobeles e Rhabditis), predadores (Ordem Mononchida) e onívoros (Dorylaimidae). 
Tabela 8. Ocorrência simultânea de Pratylenchus brachyurus, Heterodera glycines e Meloidogyne spp. em municípios da RIDE a partir de amostras de $300 \mathrm{cc}$ de solo.

\begin{tabular}{|c|c|c|c|c|c|c|c|}
\hline \multirow[t]{2}{*}{ Município/Estado } & \multirow[t]{2}{*}{ Amostra(s) } & \multicolumn{2}{|c|}{ H. glycines } & \multicolumn{2}{|c|}{ P. brachyurus } & \multicolumn{2}{|c|}{ Meloidogyne spp. } \\
\hline & & Solo & Raiz & Solo & Raiz & Solo & Raiz \\
\hline $\begin{array}{c}\text { Água Fria de Goiás } \\
\text { (GO) }\end{array}$ & 17 & ---- & ---- & 525 & 18 & 555 & 34 \\
\hline $\begin{array}{c}\text { Águas Lindas de } \\
\text { Goiás (GO) }\end{array}$ & 60 & ---- & ---- & 14 & 36 & 28 & ---- \\
\hline Buritis (GO) & 45 & ---- & ---- & 225 & 72 & 1300 & 25 \\
\hline Cabeceira Grande & 64 & 1400 & ---- & 42 & 1 & ---- & ---- \\
\hline (Goiás) & 65 & ---- & ---- & 360 & 3 & 3180 & ---- \\
\hline \multirow{4}{*}{ Cabeceiras (GO) } & 10 & ---- & ---- & ---- & 4 & 119 & 3 \\
\hline & 11 & ---- & ---- & 20 & 5 & 20 & ---- \\
\hline & 12 & $8 \mathrm{c}$ & ---- & ---- & 2 & ---- & ---- \\
\hline & 13 & ---- & ---- & ---- & 6 & ---- & 1 \\
\hline \multirow{4}{*}{ Cristalina (GO) } & 27 & 170 & 1 & 51 & 3 & ---- & ---- \\
\hline & 38 & 216 & ---- & 10 & 10 & ---- & ---- \\
\hline & 39 & 26 & ---- & 126 & 5 & ---- & ---- \\
\hline & 41 & 21 & ---- & 5 & 10 & ---- & ---- \\
\hline \multirow{4}{*}{ Planaltina (DF) } & 19 & ---- & ---- & ---- & 1 & 840 & 143 \\
\hline & 20 & ---- & ---- & 44 & 42 & ---- & 3 \\
\hline & 32 & ---- & ---- & 11 & 1 & ---- & 96 \\
\hline & 29 & 78 & 1 & 39 & 2 & ---- & ---- \\
\hline PAD-DF & 40 & 292 & ---- & 88 & 6 & ---- & ---- \\
\hline Luziânia (GO) & 51 & 1166 & ---- & 44 & 7 & ---- & ---- \\
\hline \multirow{2}{*}{ Unaí (MG) } & 55 & ---- & ---- & 176 & 35 & 60 & ---- \\
\hline & 56 & 20 & ---- & 340 & 18 & 60 & ---- \\
\hline
\end{tabular}

$\mathrm{c}=$ cistos totais/300cc de solo. 
Tabela 9. Nível populacional de nematoides por amostra em municípios da RIDE-DF (nematoides/300cc de solo).

\begin{tabular}{|c|c|c|c|c|c|c|c|c|c|c|c|c|c|c|c|c|c|c|c|c|c|c|c|c|c|}
\hline Municípios & Amostra & A1 & $\mathbf{A 2}$ & Ba & $\mathbf{C r}$ & $\mathrm{He}$ & On & Pr & $\mathbf{R r}$ & $\mathbf{T r}$ & Ty & Tn & Municípios & Amostra & A1 & $\mathbf{A 2}$ & $\mathbf{B a}$ & $\mathbf{C r}$ & $\mathbf{H e}$ & On & $\mathbf{P r}$ & $\mathbf{R r}$ & Tr & Ty & Tn \\
\hline \multirow{3}{*}{ Abadiânia } & 82 & & & & & & & & & & & & & 51 & & & 2156 & & 550 & & & & & & \\
\hline & 83 & & & 14 & & & & & & & & 14 & Luziânia & 52 & 36 & & 1476 & & 162 & 18 & & & & & 18 \\
\hline & 84 & & & 176 & & & & 16 & & & & & & 53 & & 120 & 1560 & & 1380 & 20 & & & & & \\
\hline \multirow{4}{*}{ Água Fria de Goiás } & 17 & & & 45 & & & 60 & & & & & & Mimoso & 62 & 23 & 23 & 161 & & 46 & 69 & 23 & & & & 46 \\
\hline & 35 & 63 & 38 & 438 & & 1550 & 600 & & & & & & & 47 & 52 & & 1950 & & 156 & 3432 & & & & & 26 \\
\hline & 36 & 90 & 68 & 353 & & 570 & 855 & & & 30 & & 83 & Padre Bernardo & 48 & 125 & & 625 & & 2225 & 25 & & & & & 100 \\
\hline & 37 & 24 & 36 & 468 & & 1512 & 1800 & 24 & & 108 & & 36 & & 49 & 46 & & 460 & & 46 & & & & & & 46 \\
\hline \multirow{3}{*}{ Águas Lindas de Goiás } & 59 & 34 & & 306 & & 646 & 510 & & & & & & \multirow{3}{*}{ Vila Boa } & 14 & 26 & \multirow{3}{*}{42} & \multirow{3}{*}{147} & & 26 & & & & & & \\
\hline & 60 & 84 & & 406 & & 420 & & & & & & & & 15 & 42 & & & & & & & & & & 126 \\
\hline & 61 & 238 & 14 & 420 & & 742 & 14 & & & & & 42 & & 16 & & & & & 18 & & & & & & \\
\hline \multirow{3}{*}{ Alexânia- } & 66 & 20 & 40 & 330 & & 770 & 190 & & & 20 & & 10 & \multirow{2}{*}{ Planaltina de Goiás } & 22 & 30 & & 120 & & 960 & 150 & \multirow{4}{*}{52} & & & & 120 \\
\hline & 68 & 16 & & 176 & & 3696 & 976 & 96 & & & & 240 & & 23 & 364 & & 4602 & & 2340 & 1560 & & & & & 104 \\
\hline & 69 & 30 & & 330 & & 580 & 330 & & & & & & \multirow{2}{*}{ PAD-DF Paranoá } & 25 & 15 & 38 & 593 & & 1065 & 128 & & & & & 45 \\
\hline \multirow{3}{*}{ Buritis } & 44 & & & 2961 & & 1323 & 21 & & & & & & & 40 & & 154 & 374 & & 88 & 1100 & & & & & 66 \\
\hline & 45 & & & 1525 & & 1950 & & & & & & & \multirow[t]{2}{*}{ N. R. Jardim Paranoá } & 24 & 102 & 62 & 170 & & 918 & 476 & 17 & & & & 79 \\
\hline & 46 & 416 & & 2210 & & 1924 & 2470 & & & & & 52 & & 18 & 16 & 16 & 32 & & 203 & & & & & & 16 \\
\hline \multirow{5}{*}{ Cabeceiras } & 10 & 34 & 34 & 136 & & 340 & 272 & 34 & & & & 34 & \multirow{5}{*}{ Tabatinga Planaltina } & 19 & 56 & 35 & 483 & & 910 & 952 & 42 & 133 & & & 112 \\
\hline & 11 & 40 & 20 & 160 & 20 & 1850 & 120 & 20 & & 20 & & 40 & & 29 & 260 & & 273 & & & 130 & & & 13 & & 78 \\
\hline & 12 & 125 & 25 & 75 & & 25 & 50 & & & & & & & 30 & 24 & 36 & 360 & & 384 & 60 & & & 24 & & 24 \\
\hline & 85 & & & & & & & & & & & & & 31 & 90 & & 630 & & 3420 & 702 & & & & & \\
\hline & 13 & 56 & 16 & 160 & & 560 & 64 & 24 & & & & & & 34 & 20 & 40 & 210 & & 300 & 80 & & & & & 40 \\
\hline \multirow{3}{*}{ Cidade Ocidental } & 57 & & 160 & 220 & 60 & 1520 & & 60 & & & & 220 & N.R. Taquara & 26 & 14 & 14 & 741 & & 707 & 154 & 21 & & & & 14 \\
\hline & 58 & 16 & 32 & 208 & & 1840 & & & & & & 64 & \multirow{3}{*}{ N.R Rio Preto } & 20 & & 22 & 176 & & 337 & & & & & & 22 \\
\hline & 70 & & & 90 & & 1140 & & 375 & 45 & & & 75 & & 21 & & 20 & 160 & & 220 & 80 & & & & & 20 \\
\hline \multirow{3}{*}{ Cocalzinho } & 42 & 64 & & 96 & & 704 & 272 & 32 & & & & 128 & & 32 & 11 & & 176 & & 418 & 66 & 11 & & & & 11 \\
\hline & 43 & 100 & 40 & 280 & & 840 & 740 & & & & & 80 & & 33 & 19 & 57 & 456 & & 2223 & 38 & & & & & 57 \\
\hline & 81 & 14 & 42 & 686 & & 2282 & 56 & & & & & 14 & & 63 & 45 & 15 & 180 & & 375 & 45 & & & & & 45 \\
\hline & 50 & 20 & & 1060 & & 1140 & & & & & & & Cabeceira Grande & 64 & 98 & & 98 & & 1400 & 2506 & & & & & \\
\hline Corumbá de Goiás & 67 & 52 & & & & 221 & 104 & & & & & & & 65 & 660 & & 500 & & 3180 & 103000 & & & & & \\
\hline & 27 & 17 & 17 & 544 & & 170 & 153 & & & & & 17 & & 54 & 34 & 17 & 1139 & & 799 & & 34 & & & & 34 \\
\hline & 28 & 60 & 15 & 435 & & 1755 & 90 & & & & & 30 & Unaí & 55 & 44 & 110 & 1870 & & 1364 & & & & & & \\
\hline Cristalina & 38 & & & 240 & & & 336 & & & & & 24 & & 56 & 60 & & 1760 & & 2320 & & & & & & 100 \\
\hline & 39 & & 26 & 130 & & 156 & 234 & & & & 520 & 52 & & & & & & & & & & & & & \\
\hline & 41 & & & 137 & & 462 & 158 & & & & 42 & 74 & & & & & & & & & & & & & \\
\hline & 1 & & 52 & 65 & & 351 & 247 & 13 & & & & 169 & & & & & & & & & & & & & \\
\hline Formoca & 2 & & & & & 168 & & & & & & & & & & & & & & & & & & & \\
\hline Formosa & 3 & 48 & & 348 & & 1440 & 396 & 12 & & & & 264 & & & & & & & & & & & & & \\
\hline
\end{tabular}

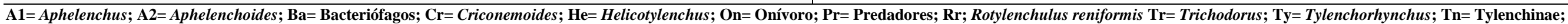




\section{Discussão}

Espécies do gênero Pratylenchus encontram-se amplamente disseminadas em áreas produtoras de alimento nas Américas (Mai et al., 1960; Huettel et al., 1991; Mitkowshi, 2002; Bao \& Neher, 2011), sendo P. brachyurus a espécie de maior importância econômica e amplamente disseminada em áreas produtoras de soja do Brasil (Dias et al., 2010). Na RIDE, esse nematoide foi encontrado em todos os municípios amostrados e em $97,1 \%$ das 70 amostras analisadas. O nível populacional de P. brachyurus detectado em amostras de solo coletadas na RIDE variou, em sua maioria, de baixo a médio. Koenning et al. (1985) relataram o nível de dano econômico para $P$. brachyurus na cultura da soja nos Estados Unidos da América do Norte (Carolina do Norte) como sendo de 275 nematoides/500gramas de solo equivalente a 165 nematoides/300 cc de solo.

O nível de infestação causado por P. brachyurus em soja é geralmente avaliado pelo nível populacional encontrado em raízes. Gilfi et al. (2003), em levantamento de nematoides realizado na cultura do algodão em 10 municípios do estado de Goiás, detectaram valores inferiores a $30 \mathrm{P}$. brachyurus $/ \mathrm{g}$ de raiz em $79 \%$ das amostras coletadas, os quais foram considerados baixos pelos autores. Das amostras de raízes analisadas nesse estudo, 85,7\% (60 amostras) apresentaram de 1 a 29 nematoides/g de raiz e média de 6,86 nematoides; 11,42\% apresentaram acima de 30 nematoides/g de raiz e média de 48,75 nematoides; Apenas 2,9\% das amostras (2 amostras) não continham P. brachyurus.

Na RIDE, P. brachyurus também foi encontrado em áreas infestadas com outros nematoides fitoparasitas de importância econômica como H. glycines e Meloidogyne spp.. A ocorrência simultânea de $P$. brachyurus e Meloidogyne spp. apresentou variações populacionais diversas para ambos os nematoides.

O aumento da área plantada com milho "safrinha" (período compreendido entre janeiro e março) provavelmente tem contribuído para o aumento do nível populacional de $P$. 
brachyurus na RIDE. Dependendo do cultivar de milho plantada e do inóculo inicial do nematoide, a população de $P$. brachyurus pode se tornar ainda maior em uma mesma safra de milho.

Como o círculo de hospedeiras de P. brachyurus é amplo (soja, feijão, algodão, milho e pastagens), as opções para rotação de verão com soja se tornam restritas. Espécies vegetais não hospedeiras como Crotalaria spectabilis e C. breviflora são opção, assim como espécies pouco favoráveis como Brachiaria humidicola, feijão Guandu Anão cv. IAPAR 43 e aveia preta (Inomoto et al., 2006). Outras espécies vegetais são consideradas moderadamente resistentes por permitir uma pequena evolução populacional de $P$. brachyurus por ciclo vegetativo. São elas milheto BRS 1501, girassol cv. IAC Uruguai e nabo forrageiro comum podem ser utilizadas em áreas infestadas com este nematoide, bem como plantas de cobertura como Quinoa BRS Pirabiru e amaranto BRS Alegria (Inomoto et al., 2006).

Asmus (2004), em levantamento realizado em Mato Grosso do Sul na cultura do algodão, constatou a presença de P. brachyurus em $82 \%$ das amostras coletadas em Chapadão do Sul, $79 \%$ das amostras de Costa Rica e $87 \%$ das amostras de São Gabriel do Oeste. Com nível populacional em 300cc variando de 15 a 345 nematoides.

\section{Meloidogyne spp.}

Sikora et al. (2011), em levantamento realizado no Alabama-EUA relataram a presença de Meloidogyne spp. em $10 \%$ e $15 \%$ das amostras, respectivamente. Roese et al. (2001), no oeste paranaense, relataram a ocorrência de $M$. javanica e $M$. incognita em $22 \%$ e $27 \%$ das amostras analisadas e Silva et al. (2004) detectaram apenas $M$. incognita em 3,7\% das amostras analisadas em levantamento realizado no estado do Mato Grosso (MT). A ocorrência de $M$. incognita nesse levantamento foi de $2,85 \%$, enquanto $M$. arenaria foi a espécie mais freqüente seguida de $M$. javanica. Franzener et al. (2005) também identificaram M. javanica e $M$. incognita em cultivos de soja do oeste do Paraná sendo $M$. javanica a 
espécie mais frequente. Castro et al. (2003), relataram M. javanica (EST-J3) como a espécie mais freqüente em 78 amostras coletadas, seguida por $M$. incognita (EST-I1) e $M$. arenaria (EST-A2), além de dois fenótipos de esterase atípicos (S1 e G3) e detecção de M. paranaensis em soja no Rio Grande do Sul e do fenótipo A3 relativo a M. morocciensis.

Das espécies de Meloidogyne citadas anteriormente, $M$. arenaria, $M$. javanica e $M$. incognita são as mais comumente relatadas e disseminadas em áreas produtoras de soja no Brasil. No entanto, em temperaturas mais amenas $M$. hapla pode ser encontrada parasitando soja, como relatado por Viaene \& Abawi (1998) e Mitkowski (2002).

Neste estudo foram identificadas, em sua maioria, populações mistas de Meloidogyne spp. Em Planaltina-DF detectou-se $M$. javanica (EST-J3) e M. arenaria (EST-A2) em mistura de populações. O fenótipo EST-J3 de $M$. javanica já havia sido relatado anteriormente por Castro et al. (2003) neste mesmo município. Eisenback \& Triantaphyllou (1991) relataram a ocorrência comum de $M$. javanica associado a $M$. incognita ou a $M$. arenaria e, às vezes, a ocorrência concomitante das três espécies em áreas cultivadas com grandes culturas. No entanto, Castro et al. (2003) detectaram, em sua maioria, espécies isoladas de Meloidogyne em diferentes municípios brasileiros produtores de soja. Segundo Dias et al. (2010) a ocorrência generalizada de $M$. javanica no Brasil, enquanto $M$. incognita predomina em áreas cultivadas anteriormente com café ou algodão. Na RIDE, a cultura do algodão e do café não são comumente encontradas. Provavelmente, a este fato se deve à baixa porcentagem de $M$. incognita em lavouras de soja.

Populações simultâneas de Meloidogyne spp. e de P. brachyurus também foram encontradas neste levantamento, além de uma população de $M$. arenaria, $P$. brachyurus e $H$. glycines no município de Unaí (MG), além de populações mistas de Meloidogyne, M. incognita foi encontrada em mistura com M. arenaria nos municípios de Cabeceiras de Goiás 
(Amostra 13) e Planaltina de Goiás (Amostra 22). Franzener et al. (2005) detectaram populações de Meloidogyne spp. e H. glycines, mas em pequena percentagem de ocorrência.

Com relação ao nível de dano estimado para Meloidogyne spp. em soja, Asmus (2001) relatou $150 \mathrm{~J} 2 / 300 \mathrm{~cm}^{3}$ de solo para $M$. javanica, $750 \mathrm{~J} 2 / 300 \mathrm{~cm}^{3}$ de solo para $M$. incognita e $210 \mathrm{~J} 2 / 300 \mathrm{~cm}^{3}$ de solo para $M$. arenaria. Considerando esses níveis de dano, para as 12 amostras detectadas com Meloidogyne na RIDE, o nível de $\mathrm{J} 2 / 300 \mathrm{~cm}^{3}$ de solo pode ser considerado elevado em apenas para 4 amostras, variando de 555 a $3180 \mathrm{~J} 2 / 300 \mathrm{~cm}^{3}$ de solo, sendo que para 8 amostras os níveis de dano foram baixos, variando de 28 a 120 J2/300 $300 \mathrm{~cm}^{3}$ de solo.

Estudos em biomas naturais como o realizado por Cares (1984) em áreas de Várzea e terra firme na Amazônia brasileira, relatou a ocorrência de espécies de Meloidogyne ( $M$. javanica, $M$. incognita e $M$. arenaria). Em solo de cerrado com cobertura vegetal nativa foram relatados $M$. javanica, $M$. incognita, $M$. arenaria, $M$. morocciensis e $M$. hapla (Sousa et al., 1994; Silva et al., 2014). Provavelmente, essas espécies já ocorriam associadas à vegetação nativa do cerrado nativo antes da sua utilização para agricultura. Portanto, o cultivo de culturas econômicas tende a selecionar a(s) espécie(s) mais adaptada(s) à cultura em questão e ao ambiente.

Na RIDE, grande parte da área agrícola em sequeiro é cultivada com soja e milho no verão e em áreas irrigadas com feijão, hortaliças, milho doce, entre outras. As espécies de Meloidogyne mais adaptadas à soja no Brasil são $M$. javanica, $M$. incognita e $M$. arenaria. É provável que o plantio de soja nas áreas amostradas neste levantamento tenha selecionado $M$. arenaria, $M$. javanica e $M$. incognita como as espécies prevalentes nesta região para as amostras positivas para Meloidogyne, sendo a maioria com populações simultâneas.

\section{Heterodera glycines}


O NCS apresenta grande variabilidade genética (Santana et al., 2009), tendo sido detectadas no Brasil as raças 1, 2, 3, 4, 4+, 5, 6, 9, 10, 14 e 14+ (Dias et al., 2009, 2010). Campos e Silva (1997), em levantamento realizado no estado de Goiás, identificaram as raças 4, 6, 9 e 14 em Jataí, raças 3, 6 e 14 em Mineiros, raças 3 e 10 em Rio Verde e raça 14 em Perolândia e Serranópolis.

Nesse estudo, H. glycines foi encontrada em amostras provenientes do Distrito Federal, Goiás e Minas Gerais. Porém, a identificação de raça fisiológica ficou restrita aos municípios de Cristalina (GO), Luziânia (GO), PAD-DF, Planaltina (DF) Cabeceira Grande (MG) e Unaí (MG). As amostras provenientes do município de Cabeceiras (GO) não apresentaram cistos em quantidade suficientes para a determinação de raça fisiológica presente. Assim, detectouse apenas a raça 3 de $H$. glycines pelo teste de hospedeiros diferenciadores (Riggs \& Schmitt, 1988). O presente trabalho encontrou o nematoide cisto em $14 \%$ das amostras.

O nível de dano para o nematoide de cisto da soja foi estimado por Schmitt \& Barker (1981) para $500 \mathrm{ml}$ de solo e classificado como moderado e alto. Segundo os autores, infestação moderada seria de 1 a 5 cistos em solo arenoso ou argilo-arenoso ou de 3 a 11 cistos em solo argiloso ou orgânico. Alta infestação ocorreria com mais de 5 cistos em solo arenoso ou argilo-arenoso ou valores superiores a 12 cistos em solo argiloso ou orgânico.

Outros nematoides fitoparasitas

A maioria das amostras de solo analisadas continha populações elevadas de Helicotylenchus spp. com uma variaçãode 18 a 3.696 nematoides/300cc de solo. Apesar desse nematoide não ser considerado de importância econômica para a cultura da soja, os níveis populacionais têm aumentado em áreas comerciais com diferentes culturas econômicas. A associação de Helicotylenchus sp. e Helicotylenchus dihystera com soja no Rio Grande do Sul já havia sido relatada por Lordello (1974) e Lehman et al. (1977), respectivamente. Sharma et al. (2001), em levantamento de nematoides fitoparasitas realizado em diferentes cultivares de 
soja em Rio Branco (AC), relataram a presença de H. dihystera em $81 \%$ das amostras de solo e $19 \%$ das amostras de raízes. As populações detectadas variaram de 0 a 6 nematoides/g de raiz e 0 a 90 nematoides $/ 100 \mathrm{~g}$ de solo e média de 11 nematoides/100g de solo. A diferença populacional encontrada no Centro-Oeste para a região norte pode chegar a mais de 1.000 nematoides/100 cc de solo. Segundo Antonio (1992), o gênero Helicotylenchus é comumente encontrado associado à soja. No entanto, o autor relata não haver relevância econômica do nematoide com a soja.

Detectou-se a presença de Criconemoides nas áreas: 3 e 11 em Formosa e Cabeceiras de Goiás respectivamente. Rotylenchulus reniformis (amostras 19 e 70) e Tylenchorhynchus spp. (amostras 29 e 30) também foram detectados. De acordo com Sikora et al. (2011), em levantamento realizado no Alabama-EUA na cultura da soja $R$. reniformis foi encontrado em $30 \%$ das amostras. No estado do Mato Grosso R. reniformis é frequentemente encontrado em algodão e soja (Silva et al., 2004). A baixa freqüência de ocorrência de $R$. reniformis na RIDE provavelmente se deve ao pouco cultivo de algodão. Trata-se do primeiro relato de $R$. reniformis e Tylenchorhynchus spp. em soja no Distrito Federal. Os demais nematoides fitoparasitas detectados neste levantamento já haviam sido relatados anteriormente em áreas de vegetação nativa do cerrado por Cares \& Huang (1991) e Mattos (1999).

\section{CONCLUSÕES}

$\checkmark$ Os nematoides fitoparasitas mais frequentemente associados à cultura da soja na RIDE foram Pratylenchus Brachyurus, Meloidogyne arenaria, M. javanica, M. incognita e Heterodera glycines raça 3;

$\checkmark$ Os níveis de Populacionais para Meloidogyne spp., H. glycines e P. brachyrus variaram entre as amostras analisadas para os diferentes municípios amostrados; 
H. glycines, $R$. reniformis e Tylenchorhynchus sp. tiveram o seu primeiro relato em soja no Distrito Federal neste levantamento.

\section{REFERÊNCIAS BIBLIOGRÁFICAS}

ABREU, E.S; YOSHIZAKI, G. \& TAKAHASHI, A.A. 2012. Avaliação da rotulagem de alimentos da culinária japonesa. Revista Univap 18(31)78-86.

ALMEIDA, A.M.R. 1992. Doenças da soja no Brasil: Epidemiologia e Controle. In: Diálogo XXXIV - Producción de Soja. PUIGNAU, J.P. IICA, Montevideo- Uruguai.

ALMEIDA, A.M.R.; FERREIRA, L.P.; YORINORI, J.T.; SILVA, J.F.V.; HENNING, A.A.; GODOY, C.V.; COSTAMILAN, L.M. \& MEYER, M.C. 2005. Doenças da soja (Glycine max). In: Kimati, H.; Amorim, L.; Rezende, J.A.M.; Bergamim Filho, A. \& Camargo, L.E.A. (Eds.) Manual de Fitopatologia. Vol. 2. Doenças das plantas cultivadas. 4a ed. Ceres. Piracicaba-SP. p. 569-588.

ALONSO, S.K. \& E ALFENAS, A.C. 1998. Isoenzimas na Taxonomia e na Genética de fitonematoides. In: Alfenas, A.C. (Ed.) Eletroforese de isoenzimas e proteínas afins, fundamentos e aplicações em plantas e microrganismos. Viçosa: UFV, 574p.

ALVES, G.C.S.; SILVA, F.A.N. \& SANTOS, J.M. 2006. Levantamento de Fitonematoides em Áreas de Algodão com Diferentes Históricos Culturais. Curso de Agronomia da Unidade Universitária de Ipameri-UEG. 6p.

ANTONIO, H. 1992. Fitonematoides na cultura da soja. Informe Agropecuário 16(172):6065.

ARANTES, N.E. \& SOUZA P.I.M. de (Ed). 1993. Cultura da soja nos Cerrados. Piracicaba: POTAFOS, $535 \mathrm{p}$.

ASMUS, G.L. \& ANDRADE, P.J.M. 1997. Reprodução de Meloidogyne incognita em cultivares de milho. Fitopatologia Brasileira 225:324. 
ASMUS, G.L. 2001. Danos causados à cultura da soja por nematoides do gênero Meloidogyne. In: Ferraz, L.C.C.B.; Asmus, G.L.; Carneiro, R.G.; Mazafera, P. \& Silva, J.F.V. Relações parasito-hospedeiro nas meloidoginoses da soja. Londrina. Embrapa Soja 39-62.

ASMUS, G.L. 2004. Ocorrência de nematoides fitoparasitos em algodoeiro no Estado de Mato Grosso do Sul. Nematologia Brasileira 28(1):77-86.

ASMUS, G.L. 2008. Reação de genótipos de soja ao nematoide reniforme. Tropical Plant Pathology 33(1):069-071.

ASMUS, G.L. \& SCHIRMANN, M.R. 2004. Reação de cultivares de soja recomendadas no Mato Grosso do Sul ao nematoide reniforme. Nematologia Brasileira 28:239-240.

AZEVEDO, L.G. de \& ADÁMOLI, J. 1988. Avaliação agroecológica dos recursos naturais da região do cerrado. In: Simpósio sobre o cerrado savanas: alimento e energia 6, Brasília, DF. 1982. Embrapa Cerrados- Planaltina-DF. p.729-761.

BAO, Y. \& NEHER, D.A. 2011. Survey of lesion and northern root-knot nematodes Associated with Vegetables in Vermont. Nematropica 41(1):100-108.

BEHRENS, J.H.; ROIG, S.M. \& DA SILVA, M.A.A.P. 2001. Aspectos de Funcionalidade de rotulagem e de aceitação de extrato hidrossolúvel de soja fermentado e culturas lácteas probióticas. Bol. SBCTA 34(2):99-106.

BLOK, V.C. \& POWERS, T.O. 2009. Biochemical and Molecular identification. In: Perry, R.N., Moens, M. \& Starr, J.L. (Ed.). CAB International. Root-knot Nematodes. p. 99118.

BOLLER, T. 1995. Chemoperception of microbial signals in plant cells. Annual Rev. Plant Physiol. Plant Mol. Biol. 46:189-214.

BRITO, J.A \& FERRAZ, S. 1987. Seleção de gramíneas antagonistas a Meloidogyne javanica. Nematologia Brasileira 11:260-269. 
CAFÉ FILHO A. \& HUANG, C.S. 1988. Nematoides do gênero Pratylenchus no Brasil. Fitopatologia Brasileira 13(3):232-235.

CÂMARA, G.M.S. 1996. A cultura da soja. Piracicaba: Universidade de São Paulo, 28p.

CAMPOS, H.D. \& SILVA, M.N. 1997. Levantamento do nematoide da soja (Heterodera glycines Ichinoe) no estado de Goiás, safras 1995/96. Fitopatologia Brasileira 22:324.

CARES, J.E. 1984. Fauna fitonematologica de várzea e terra firme nas proximidades de Manaus, AM. Dissertação de Mestrado, Brasília-DF, Universidade de Brasília.

CARES, J.H. \& HUANG, S.P. 1991. Nematode fauna in natural and cultivated cerrados of Central Brazil. Fitopatologia Brasileira 16:199-209.

CARLSON, J.B. \& LERSTEN, N.R. 2004. Reproductive morphology. In: Boerma, R. \& Specht, J.E. (Ed.). Soybeans: improvement, production, and uses. 3rd ed. Madison: Soil Science Society of America, p.59-95.

CARNEIRO, R.M.D.G.; RANDIG, O.; ALMEIDA, M.R.A. \& GONÇALVEZ W. 2005. Identificação e caracterização de espécies de Meloidogyne em cafeeiro nos estados de São Paulo e Minas Gerais através de tipos de esterase e SCARS multiplex. Nematologia Brasileira 29(2):233-241.

CARNEIRO, RMDG.; SANTOS, MFA.; ALMEIDA, M.R.A.; MOTA, F.C.; GOMES, A.C.M.M.; TIGANO, M.S. 2008. Diversity of Meloidogyne arenaria using morphological, cytological and molecular approaches. Nematology 10:819-834.

CARRÃO-PANIZZI, M.C.; BERTAGNOLLI, P.F.; STRIEDER, M.L.; COSTAMILAN, L.M. \& MOREIRA, J.U.V. 2012. Melhoramento de soja para alimentação humana na Embrapa Trigo - Safra Agrícola 2011/2012 In: COSTAMILAN, L.M. Soja: resultados de pesquisa 2011/2012. (Documentos / Embrapa Trigo, ISSN 1516-5582;111) Embrapa/Mapa. 1ªed. Passo Fundo-RS. p.27-31. 
CASTILLO, P. \& VOVLAS, N. 2007. Pratylenchus (Nematoda: Pratylenchidae): diagnostic, biology, pathogenicity and management. Hunt, D.J. \& Perry, R.N. (Eds). Nematology monographs and perspectives, vol. 6. Leiden. The Netherlands, Brill Academic Publishers, 529 pg.

CASTRO, A.P.G. 2008. Maracujazeiros comerciais e silvestres: nematoides associados e variabilidade genética com base em marcadores moleculares e na resistência a Meloidogyne incógnita. [Dissertação de Mestrado] Universidade de Brasília. Departamento de Fitopatologia. Brasília-DF. 70p.

CASTRO, J. M. C.; LIMA, R. \& CARNEIRO, R. M. D. C. 2003. Variabilidade isoenzimática de populações de Meloidogyne spp. proveniente de regiões brasileiras produtoras de soja. Nematologia Brasileira 27(3):1-12.

COBER, E.R.; CIANZION, S. R.; PANTALONE, V.R. \& RAJCAN, I. 2009. Soybean. In: Oil Crops. Vollmann, J. \& Rajcan, I. (eds). Springer, New York, USA. p: 57-90.

COOLEN, W.A. \& D'HERDE, C.J. 1972. A method for the quantitative extraction of nematodes from plant tissue. State Agricultural Research Centre - GHENT, Belgium. $77 \mathrm{p}$.

CONAB - Companhia Nacional de Abastecimento. Acompanhamento da safra brasileira de grãos, v.1 - safra 2013/2014, n.10 - Décimo levantamento jul.2014.

CONAB - Companhia Nacional de Abastecimento. Acompanhamento da safra brasileira de grãos, v.2 - Safra 2014/15 n.10 - Décimo Levantamento Julho/2015

COOPA-DF- PROGRAMA DE ASSENTAMENTO DIRIGIDO DO DISTRITO FEDERAL. 2015. Disponível em http://www.coopadf.com.br/o-pad-df 03/10/2015.

CREECH, J.E.; JOHNSON, W.G.; FAGHI, J. \& FERRIS, V.R.. 2007. Survey of Indiana Producers and Crop Advisors: A Perspective on Winter Annual Weeds and Soybean Cyst Nematode (Heterodera glycines). Weed Technology 21(2):532-536. 
CURTIS, R.H.C; ROBINSON, A.F. \& ROLAND, N.P. 2009. Hatch and Host Location. In: Perry, R.N., Moens, M. \& Starr, J.L. (Eds) CAB International. Root-knot Nematodes. p.139-162.

DAWSON, M.N.; RASKOFF, K.A.; \& JACOBS, DAVID, K. 1998. Field preservation of marine invertebrate tissue for DNA analyses. Molecular Marine Biology and Biotechnology 7(2): 145-152.

DHINGRA, O.D.; MENDONÇA, H.L. \& MACEDO, D.M. 2009. Doenças e seu controle. In: SEDIYAMA, T. (Ed.). Tecnologias de produção e usos da soja. Londrina: Mecenas, p.133-155.

DIAS-ARIEIRA, C.R.; FERRAZ, S.; FREITAS, L.G. de \& MIZOBUTSI, E.H. 2003. Avaliação de gramíneas forrageiras para o controle de Meloidogyne incognita e $M$. javanica (Nematoda). Acta Scientiarum. Agronomy 25(2):473-477.

DIAS, W.P.; GARCIA, A.; SILVA, J.F.V.; CARNEIRO, G.S.S. 2010. Nematoides em Soja: Identificação e Controle. Circular Técnica 76. Londrina, PR, abril.

DIAS, W.P.; SILVA, J.F.V.; CARNEIRO, G.E.S.; GARCIA, C \& ARIAS, C.A.A. 2009. Nematoide de cisto da soja: Biologia e manejo pelo uso da resistência genética. Nematologia Brasileira 33(1):1-16.

DIAS, W.P.; SILVA, J.F.V.; GARCIA, A. \& CARNEIRO, G.E.S. 2004. Biologia e controle do nematoide de cisto da soja (Heterodera glycines Ichinohe). In: Resultados de Pesquisa da Embrapa Soja-2003: Ecofisiologia, biologia molecular e nematoides. Embrapa Soja, Londrina, 48 p.

DIAS, W.P.; FREITAS, V.M.; RIBEIRO, N.R.; MOITA, A.W.; HOMECHIN, M.; PARPINELLI, N.M.B. \& CARNEIRO, R.M.D.G. 2010. Reação de genótipos de soja a Meloidogyne enterolobii e M. ethiopica. Nematologia Brasileira 34(4):220-225. 
DUNCAN, L.W. \& MOENS, M. 2006. Migratory Endoparasitic Nematodes. In: PERRY, R.N. \& MOENS, M (Ed.). Plant Nematology. UK/London-England. p.123-152.

EISENBACK, J.D. \& TRIANTAPHYLLOU, H. 1991. Root-Knot nematode: Meloidogyne sp. and races. In: Nickle, W. R. (ed). Manual of agricultural Nematology. New York, p.191-274.

EMBRAPA- Empresa Brasileira de Pesquisa Agropecuária. 2004. Tecnologias de produção de soja $\quad-$ Região Central do Brasil 2004. < http://www.cnpso.embrapa.br/producaosoja/doenca.htm > Consultado em : 27/07/2015

EMBRAPA- Empresa Brasileira de Pesquisa Agropecuária. 2013. Tecnologias de produção de soja - Região Central do Brasil 2014. - Londrina: Embrapa Soja. 268 p.

ESBENSHADE, P.R. \& TRIANTAPHYLLOU, A.C. 1987. Enzymatic relationships and evolution in the genus Meloidogyne (Nematoda: Tylenchida). Journal of Nematology. 19:8-18.

ESBENSHADE, P.R. \& TRIANTAPHYLLOU, A.C. 1990. Isozyme phenotypes for identification of Meloidogyne species. Journal of Nematology 22:10-15.

EVANS, A.A.F. 1998. Reproductive mechanisms. In: Perry, R.N. \& Wright, D.J. (Eds). The physiology and biochemistry of free -living and parasitic nematodes. Wallingford, CAB International. p. 133-154.

FAOSTATE- FOOD AND AGRICULTURE ORGANIZATION OF THE UNITED NATIONS STATISTICS DIVISION . 2015. http:/faostat3.fao.org/ Acesso em 03/10/2015.

FERRARI, R.A.; OLIVEIRA, V.D. \& SCABIO, A. 2005. Biodiesel de soja - Taxa de Conversão em ésteres etílicos, caracterização físico-química e consumo em gerador de energia. Química Nova 28(1):19-23. 
FERRAZ, S.; FREITAS, L. G.; LOPES, E. A. \& DIAS-ARIEIRA, C. R. 2010. Manejo Sustentável de Fitonematoides. Viçosa, MG: UFV. 306 p.

FERRAZ, L.C.C.B. 1995. Patogenicidade de Pratylenchus brachyurus a três cultivares de soja. Nematologia Brasileira 19:1-8.

FERRAZ, L.C.C.B. \& MONTEIRO, A.R. 2011. Nematoides. In: Kimati, H.; Amorim, L.; Rezende, J.A.M.; Bergamim Filho, A. \& Camargo, L.E.A. (Eds.) Manual de Fitopatologia. Vol. 1. Princípios e conceitos. 4a ed. Ceres. Piracicaba-SP. p. 277-305.

FERRAZ, S.; VALLE, L. A. C. 1995. Utilização de plantas antagônicas no controle de fitonematoides. In: CONGRESSO INTERNACIONAL DE NEMATOLOGIA TROPICAL, 4. Rio Quente. Anais. Rio Quente: SBN/ONTA, p.257-276.

FRANZENER, G.; UNFRIED, J.G.; STANGARLIN, J.R. \& FURLANETTO, C. 2005. Nematoides formadores de galha e de cisto patogênicos à cultura da soja em municípios do oeste do Paraná. Nematologia Brasileira 29 (2):261-265.

FREITAS, L.G.; OLIVEIRA, R.D.L. \& FERRAZ, S. 2004. Introdução à Nematologia. Viçosa: Editora UFV, (Caderno didático, 58) 84p., 1. Ed., 2ª reimpressão.

GARRIDO, W.E.; AZEVEDO, L.G. de \& JARRETA JUNIOR, M. 1982. O clima da região dos cerrados em relação a agricultura. Embrapa Cerrados- Planaltina-DF. Comunicado Técnico 4. 37p.

GIELFI, F.S.; SANTOS, J.M. \& ATHAYDE, M.L.F. 2003. Reconhecimento das espécies de fitonematóides associadas ao algodoeiro (Gossypium hirsutum L.) no estado de Goiás. In: CONGRESSO BRASILEIRO DO ALGODÃO, Goiânia. Campina Grande: Embrapa Algodão.

GOMES, P. 1990. A soja. $5^{\text {a }}$ ed. Nobel. São Paulo-SP. 
HARTMAN, K.M. \& SASSER. 1985. Identification of Meloidogyne species on the basis of differential host test and perineal-patter morphology. North Carolina State University, Raleigh, v.2, p. 69-77.

HARTMAN, L. \& ESTEVES, W. 1989. Tecnologia de Óleos e Gorduras Vegetais na indústria de Alimentos. Secretaria da Indústria, Comércio, Ciências e Tecnologia: São Paulo.

HIRSCHMANN, H. 1985. The genus Meloidogyne and morphological characters differentiating its species, In: SASSER, J.N. \& CARTER, C.G. (Eds). An advanced treatise on Meloidogyne. Vol. 1. Biology and control. Raleigh, NC, USA, North Carolina State University Graphics. p. 79-93.

HOGAN, D. J.; CUNHA, J. M. C.; CARMO, R. L. 2002. Uso do solo e mudança de sua cobertura no centro-oeste do Brasil: conseqüências demográficas, sociais e ambientais. In: Hogan, D.J.; Carmo, R.L.; Cunha, J.M.P.; Baeninger, R. (org.). Migração e ambiente no centro-oeste. Campinas: NEPO/UNICAMP- PRONEX, p. 149-174.

HOOPER, D.J. 1986. Handling, fixing, staining and mounting nematodes. In: SOUTHEY, J.F. (ed). Laboratory methods for work with plant and soil nematodes. Her Majesty's Stationery Office, London. p. 59-80.

HUANG, C.S.; MOTA, E. \& SILVA, E.F.S. 1980. Interrupção do ciclo vital de Meloidogyne incognita por Crotalaria spp. Fitopatologia Brasileira 55:402-403.

HUANG. C.S. \& CHARCHAR, J.M. 1981. Período de permanência de Crotalaria spectabilis no campo influenciando no controle de meloidoginose em cenoura. Fitopatologia Brasileira. 65:538-539.

HUETTEL, R. N.; FRANCL, L. J.; REISE, R. W.; MEYER, S. L. F. \& HENN, R. A. 1991. Plant-parasitic nematodes in the potato growing areas of Maine. American. Potato Journal 68:345-354. 
HYMOWITZ, T. 1970. On the domestication of the soybean. Economic Botani, 24:408-421.

HYMOWITZ, T. \& NEWELL, C.A. 1981. Taxonomy of the genus Glycine, domestication and uses of soybeans. Economic Botany 35(3):272-288.

INOMOTO, M.M.; ASMUS, G.L.; SILVA, R.A.;MACHADO, A. C. Z. 2007. Nematoides: Uma ameaça á cotonicultura brasileira. São Paulo : Syngenta Proteção de Cultivos Ltda. $15 \mathrm{p}$.

INOMOTO, M.M., MOTTA, L.C.C., MACHADO, A.C.Z., SAZAKI, C.S.S. 2006. Reação de dez coberturas vegetais a Pratylenchus brachyurus. Nematologia Brasileira 30(2):151157.

JAEHN, A.; MENDES, M.L. \& SILVA, M.F.A. 1998. Nematoides fitoparasitos associados a cultura da soja Glycine max (L.) Merr, no Vale do Paranapanema, SP. Nematologia Brasileira 22(1):79-81.

JENKINS, W.R. 1964. A rapid centrifugal-flotation technique for separating nematodes from soil. Plant Disease Reporter, Saint Paul, v. 48: 692, 1964.

KOENNING, S.R; KIRKPATRICK, T.L.; STARR, J.L.; WALKER, N.A.; WRATHER, J.A. \& MUELLER, J.D. 2004. Plant-parasitic nematodes attacking cotton in the U.S.: Old and emerging problems. Plant Disease 88:100-113.

KOENNING, S.R; SCHMITT, D.P. \& BARKER, K.R. 1985. Influence of Planting Date on Population Dynamics and Damage Potential of Pratylenchus brachyurus on Soybean. Journal of Nematology 17(4):428-436.

LEHMAN, P.S.; ANTÔNIO, H. \& BARKER, K.R. 1977. Ocorrência de Nematóides em soja nos Estados de Minas Gerais, Goiás e Mato Grosso. II Reunião de Nematologia. Soc. Brasil. Nemat. $n^{\circ}$ 2:29-32.

LIMA, R.D.; FERRAZ, S. \& SANTOS, J.M. dos. 1992. Ocorrência de Heterodera sp., em soja no Triângulo Mineiro. Nematologia Brasileira, Brasília, v. 16, n. 1/2:101-102. 
LIMA, F.S.O.; NOGUEIRA, S.R.; LIMA NETO, A.F.; CARES, J.E.; FURLANETTO, C. \& DIAS, T.S. 2009. Ocorrência de Tubixaba sp. em lavouras comerciais de soja no estado de Tocantins. Tropical Plant Pathology 34 (Supl.):207.

LORDELLO, L.G. 1974. Alguns nematóides parasitos de plantas do Rio Grande do Sul. Revista de Agricultura 49:15-18.

MACHADO, A. C. Z., FERRAZ, L. C. C. B \& OLIVEIRA, C. M. G. 2007. Development of a species-specific reverse primer for the molecular diagnostic of Pratylenchus brachyurus. Nematropica 37 (2):249-257.

MAI, W. F.; CRITTENDEN, H. W. \& JENKINS, W. R. 1960. Distribution of stylet-bearing nematodes in the northeastern United States. Northeast Regional Research Publication 795:1-62.

MATTOS, J.K.A. 1999. Caracterização das comunidades de nematoides em oito sistemas de uso da terra nos cerrados do Brasil Central. Universidade de Brasília. Tese de Doutorado. 113p.

MITCHUM, M.G.; WRATHER, J.A.; HEIZ, R.D., SHANNON, J.G. \& DANEKAS, G. 2007. Variability in distribution and virulence phenotypes of Heterodera glycines in Missouri during 2005. Plant Disease 91:1473-1476.

MITKOWSKI, N. A.; VAN DER BEEK, J. G. \& ABAWI, G. S. 2002. Characterization of root-knot nematode populations associated with vegetables in New York State. Plant Disease 86:840-847.

MOENS, M.M.; ROLAND, N.P. \& STARR, J.L. 2009. A Diverse group of novel and important plant parasites. In: Perry, R.N., Moens, M. \& Starr, J.L. (eds). CAB International. Root-knot nematodes. p.1-17. 
MONTEIRO, A. R. \& LORDELLO, L. G. 1980. Tubixaba tuxaua N.G. N.SP., a suspected parasitic nematode of soybean roots (Aporcelaimidae). Revista de Agricultura 55:301304.

MOORE, W.F; BOST, S.C.; BREWER, F.L.; DUN RA, E.N.D.O. BY; GRAU, C.R.; HARDMAN, L.L.; JACOBSEN, B.J.; LEFFEL, R.; NEWMAN, M.A.; NYVALL, R.F.; OVERSTREET, C. \& PARKS, C.L. 1984. Soybean cyst nematode. Soybean Industry Resource Committee, Washington, 23 p.

MORGAN, E.T. \& VIEIRA, S.A. 1996. A composição e a quantidade de gordura nas dietas afetam a eficiência alimentar das aves. In: Encontro de Nutricionistas, II. 1996, Santiago, Anais. Pfizer, p.18-21.

NOGUEIRA, M.A.; OLIVEIRA, J.S.; FERRAZ, S. \& SANTOS, M.A. 1997. The activity of Mucuna deeringiana and Chenopodium ambrosioides crudes extracts upon Meloidogyne incognita raça 3. Rev. Ceres 44 (1):124-127.

OERKE, E.C.; DEHNE, H.W.; SCHONBECK, F. \& WEBER, A. 1994. Crop Production and Crop protection: Estimated Losses in Major Food and Cash Crops. Amsterdã Agricultural Bureaux.

POWERS, T.O. \& HARRIS, T.S.. 1993. A polymerase chain rection method for identification of five major Meloidogyne species. Journal of Nematology 25:1-6.

PETERSEN, D.J.; ZILSTRA, C.; BLOCK, V. \& VRAIN, T.C.. 1997. Species probes efficiently distinguish root-knot nematodes specie using signatures in the ribossomal intergenic spacer. Fundamental and Applied Nematology 20:619-626.

RANDIG, O.; CARNEIRO, R.M.D. \& CASTAGNONE-SERENO, P. 2004. Principais Espécies de Meloidogyne parasitas do cafeeiro no Brasil com marcadores SCAR-Café em Multiplex-PCR. Nematologia Brasileira 28(1):1-10 
RANDIG, O.; CARNEIRO, R.M.D. \& CASTAGNONE-SERENO, P. 2002. Genetic diversity of root-knot nematodes from Brazil and development of SCAR markers specific for the coffee-damaging species. Genome 45:862-870.

RIBEIRO, L.M.; CAMPOS, H.D.; TESSMANN, D.J.; DIAS-ARIEIRA, C.R.; NEVES, D.L. das \& SILVA, C.N. da. 2013. Identification of Pratylenchus spp. in soybean in Central region of Brazil using the ITS-5.8S rDNA region. , 21 November, African Journal of Agricultural Research 8(45):5699-5702.

RIBEIRO, N.R.; DIAS, W.P.; HOMECHIN, M.; SILVA, J.F.V.; FRANCISCO, A. 2007. Reação de alguns genótipos de soja a Pratylenchus brachyurus. XXVII Congresso Brasileiro de Nematologia. Nematologia Brasileira 37(2)157-158.

RIGGS, R.D., D.A. SLACK \& M.L. HAMBLEN. 1968. New biotype of soybean cyst nematode. Arkansas Farm Research 17:11.

RIGGS, R.D., M.L. HAMBLEN \& D.A. SLACK. 1981. Intraspecies variation in reaction to hosts in Heterodera glycines populations. Journal of Nematology 13:171-179.

RIGGS, R.D., D.P. SCHMITT. 1988. Complete characterization of the race scheme for Heterodera glycines. Journal of Nematology 20:392-395.

ROBBINS, RT, RAKES, L. 1996. Resistence to the reniform nematode in selected soybean cultivars and germplasm lines. Journal of Nematology 28:612-615.

ROBINSON, A.F.; INSERRA, R.N.; CASWELL-CHEN, E.P.; VOVLAS, N.; TROCCOLI, A. 1997. Rotylenchulus species: Identification, distribution, host ranges, and crop plant resistance. Nematropica 27:127-180.

ROESE, A.D.; ROMANI, R.D.; FURLANETTO, C.; STARGALIN, J.R. \& PORTZ, R.L.. 2001. Levantamento de doenças na cultura da soja, Glycine max (L.) Merrill, em municípios da região Oeste do Estado do Paraná. Acta Scientiarum 23(5):1293-1297. 
ROESE, A.D.; OLIVEIRA, R.D.L \& LANES, F.F.de. 2004. Reação de cultivares de soja (Glycine max L. Merril) a Meloidogyne paranaensis. Nematologia Brasileira 28:131135.

ROSA, A.M.; ClAVISO, J.; PASSOS, L.M.L. \& AGUIAR, C.L. 2009. Alimentos fermentados à base de soja (Glycine max (Merrill) L.): importância econômica, impacto na saúde e efeitos associados às isoflavona e seus açúcares. Revista Brasileira de Biociências 7(44), out./dez.

ROSA, H.; MANZANILLA-LOPES; EVANS, K. \& BRIDGE, J. 2004. Plant Disease Caused by Nematodes. In: CHEN, Z.X.; CHEN, S.Y. \& DICKSON, D.W. Nematology: advances and perspectives. Vol.2, p. 637-716.

ROSS, J. P. Physiological strains of Heterodera glycines. 1962. Plant Disease Reporter 46: 766-769.

SANTANA, H.; PIRES, E.; CORMELATO, A.P.; NASU, E.G.C \& FURLANETTO, C. 2009. Variabilidade genética em populações de campo do nematoide de cisto da soja provenientes dos estados do Paraná e Rio Grande do Sul. Tropical Plant Pathology 34(4):261-264.

SCHMITT, D.P. \& BARKER, K.R. 1981. Damage and reproductive potencials of Pratylenchus brachyurus and Pratylenchus penetrans on soybean. Journal of Nematology 13:327-332.

SCHMUTZ, J.; CANNON, S. B.; SCHLUETER, J.; MA, J.; MITROS, T., NELSON, W.; HYTEN, D. L.; SONG, Q.; THELEN, J. J.; CHENG, J.; XU, D.; HELLSTEN, U.; MAY, G. D.; YU, Y.; SAKURAI, T.; UMEZAWA, T. BHATTACHARYYA, M. K.; SANDHU, D.; VALLIYODAN, B.; LINDQUIST, E.; PETO, M.; GRANT, D.; SHU, S.; GOODSTEIN, D.; BARRY, K.; FUTRELL-GRIGGS, M.; ABERNATHY, B.; DU, J.; TIAN, Z.; ZHU, L.; GILL, N.; JOSHI, T.; LIBAULT, M.; SETHURAMAN, A.; 
ZHANG, X. C.; SHINOZAKI, K.; NGUYEN, H. T.; WING, R. A.; CREGAN, P.; SPECHT, J.; GRIMWOOD, J.; ROKHSAR, D.; STACEY, G.; SHOEMAKER, R. C. \& JACKSON, S. A. 2010. Genome sequence of the palaeopolyploid soybean. Nature 463: 178-83.

SEDIYAMA, T. 2009. Tecnologias de produção e usos da soja. Londrina: Macenas.314 p

SHARMA, R. D.; CAVALCANTE, M. J. B. de.; VALENTIM, J. F. 2001. Nematóides associados ao capim Brachiaria brizantha cv. Marandu no estado do Acre, Brasil. Nematologia Brasileira 25(2):217-222.

SHARMA, R.D. \& AMABILE, R.F. 2004. Nematóides Associados ao Girassol em Áreas de Cerrado do Distrito Federal. Boletim de Pesquisa e Desenvolvimento 125. PlanaltinaDF. 13p.

SIKORA, E.J.; MURPHY; J.F.; LAWRENCE, K.S. \& MULLEN, J.N. 2011. Survey of fungal, Nematode and Virus Diseases of Soybean in Alabama. Plant Management Network. Online. Plant Health Progress doi:10.1094/PHP-2011-1227-01-RS.

Disponível em: http://www.plantmanagementnetwork.org/pub/php/research/2011/soybean/ . Acesso em: 07 agos 2015

SILVA, F.G. 2007. Levantamento de Fitonematoides nas culturas de soja e milho no município de Jataí-GO. [Dissertação de Mestrado] Universidade Federal de Uberlândia. Instituto de Ciências agrárias programa de pós-graduação em agronomia, UberlândiaMG. 48p.

SILVA, J.A.L. 1998. Identificação de raças fisiológicas de Heterodera glycines Ichinoh e a avaliação da resistência de genótipos de soja [Glycine max (L.) Merrill]. 58f. (Tese de Doutorado em Fitotecnia) - Universidade Federal de Viçosa, Viçosa, MG. 
SILVA, J.F.V.; MACEDA, A.; DIAS, W.P.; SANTOS, J.M.; MARCONDES, M.C. \& LIMA, C.G. 2009. Ocorrência do nematoide Scutellonema sp. associado a danos em lavouras de soja no Brasil. In: CONGRESSO BRASILEIRO DE SOJA, 5.; MERCOSOJA 2009, Goiânia. Anais. Londrina: Embrapa Soja, 2009. Seção trabalhos, t. 308. 1 CD-ROM. Editado por Adilson de Oliveira Júnior, Odilon Ferreira Saraiva, Clara Beatriz Hoffmann Campo, César de Castro.

SILVA, J.G.P; FURLANETTO, C.; ALMEIDA, M.R.A.; ROCHA, D.B.; MATTOS, V.S.; CORREA, V.R.; CARNEIRO, R.M.D.G. 2014. Occurrence of Meloidogyne spp. in Cerrado Vegetations and Reaction of Native Plants to Meloidogyne javanica. Journal of Phytopathology. 162 449-455.

SILVA, R.A.; SERRANO, M.A.S.; GOMES, A.C.; BORGES, DC; SOUZA, A.A.; ASMUS, G.L. \& INOMOTO, M.M. 2004. Ocorrência de Pratylenchus brachyurus e Meloidogyne incognita na cultura do algodoeiro no Estado do Mato Grosso. Fitopatologia Brasileira 29(3):337.

SOUZA, R.M.; DOLINSKI, C.M.;HUANG, S.P. 1994. Survey of Meloidogyne spp. in native cerrado of Distrito Federal, Brazil. Fitopatologia Brasileira, v. 19, n.3, p. 463-465.

SUDECO- Superintendência do Desenvolvimento do Centro-Oeste. Disponível em:

http://www.sudeco.gov.br/ride-df. Acesso em: 02/10/2015

TOWNSHEND, J.L. 1990. Method for evaluating resistance to lesion nematodes, Pratylenchus species. In: STARR, J.L. (ed.). Methods for evaluating plant species for resistence to plant parasitic nematodes. Hyattsville, Maryland: The Society of Nematologists. p. 33-41.

TURNER, S.J \& ROWE, J.A. 2006. Cyst nematodes. In: Perry, R.N. \& Moens, M (Ed.). Plant Nematology. UK/London-England. p. 91-122. 
URBEN FILHO, G. \& SOUZA, P.I.M. 1993. Manejo da cultura da soja sob cerrado: época, densidade e profundidade de semeadura. In: ARANTES, N.E.; SOUZA, P.I.M. Cultura da soja nos cerrados. Piracicaba: Potafós, p. 267-298.

USDA, 2015. United States Department of Agriculture. Disponível em: <http://apps.fas.usda.gov/psdonline/psdReport.aspx?hidReportRetrievalName=Table+1 1+Soybean+Area\%2c+Yield\%2c+and+Production\&hidReportRetrievalID=906\&hidRe portRetrievalTemplateID $=1>$

VIAENE, N.M. \& ABAWI, G.S. 1998. Management of Meloidogyne hapla on lettuce in organic soil with sudangrass as a cover crop. Plant Disease 82:945-952.

WEAVER, D.B.; RODRÍGUES-CABANA, R. \& CARDEN, E.L. 1993. Velvetbean in rotation with soybean for management of Heterodera glycines and Meloidogyne arenaria. Journal of Nematology. 25(4S):809-813.

WEI-GUO, L.; JUN-YI, G. \& WEI-DONG, L. 2006. Samplig Survey and Identification of Races of Soybean Cyst Nematode (Heterodera glycines Ichinohe) I Huang-huai Valleys. Agricultural Sciences in China 5(8):615-621.

ZIJLSTRA, C. 2000. Identification of Meloidogyne chitwoodi, M. fallax and M. hapla based on SCAR-PCR: a powerful way of enabling reliable identification of populations or individuals that share common traits. European Journal of Plant Pathology 106:283-290.

ZIJLSTRA, C.; DONKERS-VENNNE, D.T.H.M. \& FARGETTE, M. 2000. Identification of Meloidogyne incognita, M. javanica and M. arenaria using sequence characterised amplified region (SCAR) based PCR assays. Nematology 2(8):847-853. 


\section{ANEXO 1}

Tabela 10. Raça de Heterodera glycines em Cristalina-GO.

\begin{tabular}{lccccccccc}
\hline \multicolumn{7}{c}{$\begin{array}{c}\text { População do NCS: Cristalina- GO } \\
\text { Inoculação: } 3.000 \text { ovos/planta em } 07 / 05 / 14 \\
\text { Avaliação: 04/06/2014 }\end{array}$} & \\
\cline { 2 - 8 } Diferenciadoras & $\mathbf{1 *}^{*}$ & $\mathbf{2}$ & $\mathbf{3}$ & $\mathbf{4}$ & $\mathbf{5}$ & $\mathbf{6}$ & Média & & \\
\hline IF (\%) & Reação \\
\hline Pickett & 0 & 0 & 0 & 0 & 0 & 0 & 0,0 & 0,0 & Resistente \\
Peking & 0 & 0 & 0 & 0 & 0 & 0 & 0,0 & 0,0 & Resistente \\
PI 88788 & 0 & 1 & 3 & 1 & 0 & 1 & 1,0 & 1,8 & Resistente \\
PI 90763 & 0 & 0 & 0 & 0 & 0 & 0 & 0,0 & 0,0 & Resistente \\
HARTWIG & 0 & 0 & 0 & 0 & 0 & 0 & 0,0 & 0,0 & Resistente \\
PI 437654 & 0 & 0 & 0 & 0 & 0 & 0 & 0,0 & 0,0 & Resistente \\
Lee 74 & 52 & 27 & 143 & 20 & 28 & 63 & 55,5 & 100,0 & Suscetível \\
\hline
\end{tabular}

$* \mathrm{~N}^{\circ}$ de Fêmeas/sistema radicular.

$\operatorname{IF}(\%)=($ média de fêmeas na diferenciadora / média de fêmeas em Lee 74) $\times 100$

Suscetível $=\mathrm{IF}>$ ou $=10 \%$; Resistente $=\mathrm{IF}<10 \%$.

Ficou constatado que a população do NCS pertence à raça 3 .

Tabela 11. Raça de Heterodera glycines em Luziânia-GO.

\begin{tabular}{|c|c|c|c|c|c|c|c|c|c|}
\hline \multicolumn{10}{|c|}{$\begin{array}{c}\text { População do NCS: Luziânia- GO } \\
\text { Inoculação: } 1.500 \text { ovos/planta em 07/05/14 } \\
\text { Avaliação: } 04 / 06 / 2014\end{array}$} \\
\hline \multirow[b]{2}{*}{ Diferenciadoras } & \multicolumn{7}{|c|}{ Repetições } & \multirow[b]{2}{*}{ IF $(\%)$} & \multirow[b]{2}{*}{ Reacão } \\
\hline & $1^{*}$ & 2 & 3 & 4 & 5 & 6 & Média & & \\
\hline Pickett & 0 & 0 & 0 & 0 & 0 & 0 & 0,0 & 0,0 & Resistente \\
\hline Peking & 0 & 0 & 0 & 0 & 0 & 0 & 0,0 & 0,0 & Resistente \\
\hline PI 88788 & 0 & 0 & 0 & 0 & 0 & 0 & 0,0 & 0,0 & Resistente \\
\hline PI 90763 & 0 & 0 & 0 & 0 & 0 & - & 0,0 & 0,0 & Resistente \\
\hline HARTWIG & 0 & 0 & 0 & 0 & 0 & 0 & 0,0 & 0,0 & Resistente \\
\hline PI 437654 & 0 & 0 & 0 & 0 & 0 & 0 & 0,0 & 0,0 & Resistente \\
\hline Lee 74 & 30 & 22 & 34 & 73 & 39 & 83 & 46,8 & 100,0 & Suscetível \\
\hline
\end{tabular}

$* \mathrm{~N}^{\circ}$ de Fêmeas/sistema radicular.

$\operatorname{IF}(\%)=($ média de fêmeas na diferenciadora / média de fêmeas em Lee 74) $\times 100$

Suscetível $=\mathrm{IF}>$ ou $=10 \% ;$ Resistente $=\mathrm{IF}<10 \%$.

Ficou constatado que a população do NCS pertence à raça 3 . 
Tabela 12. Raça de Heterodera glycines no PAD-DF e Planaltina-GO.

\begin{tabular}{|c|c|c|c|c|c|c|c|c|c|}
\hline \multicolumn{10}{|c|}{$\begin{array}{c}\text { População do NCS: PAD-DF- Planaltina- GO } \\
\text { Inoculação: } 4.000 \text { ovos/planta em 07/05/14 } \\
\text { Avaliação: 04/06/2014 }\end{array}$} \\
\hline \multirow[b]{2}{*}{ Diferenciadoras } & \multicolumn{7}{|c|}{ Repetições } & \multirow[b]{2}{*}{ IF $(\%)$} & \multirow[b]{2}{*}{ Reação } \\
\hline & $1 *$ & 2 & 3 & 4 & 5 & 6 & Média & & \\
\hline Pickett & 2 & 0 & 0 & 0 & 0 & - & 0,4 & 0,3 & Resistente \\
\hline Peking & 0 & 0 & 0 & 0 & 0 & 0 & 0,0 & 0,0 & Resistente \\
\hline PI 88788 & 8 & 0 & 0 & 1 & 1 & 1 & 1,8 & 1,4 & Resistente \\
\hline PI 90763 & 0 & 0 & 0 & 0 & 0 & - & 0,0 & 0,0 & Resistente \\
\hline HARTWIG & 0 & 0 & 0 & 0 & 0 & 1 & 0,2 & 0,1 & Resistente \\
\hline PI 437654 & 0 & 0 & 0 & 0 & 0 & 0 & 0,0 & 0,0 & Resistente \\
\hline Lee 74 & 36 & 124 & 173 & 185 & 192 & 66 & 129,3 & 100,0 & Suscetível \\
\hline
\end{tabular}

Tabela 13. Raça de Heterodera glycines em Cabeceira Grande-MG e Unaí-MG.

\begin{tabular}{|c|c|c|c|c|c|c|c|c|c|}
\hline \multicolumn{10}{|c|}{$\begin{array}{c}\text { População do NCS: Cabeceira Grande- MG } \\
\text { Inoculação: } 1.500 \text { ovos/planta em 07/05/14 } \\
\text { Avaliação: } 04 / 06 / 2014\end{array}$} \\
\hline \multirow[b]{2}{*}{ Diferenciadoras } & \multicolumn{7}{|c|}{ Repetições } & \multirow[b]{2}{*}{ IF $(\%)$} & \multirow[b]{2}{*}{ Reação } \\
\hline & $1 *$ & 2 & 3 & 4 & 5 & 6 & Média & & \\
\hline Pickett & 0 & 0 & 0 & 0 & 0 & 0 & 0,0 & 0,0 & Resistente \\
\hline Peking & 0 & 0 & 0 & 0 & 0 & 0 & 0,0 & 0,0 & Resistente \\
\hline PI 88788 & 0 & 0 & 0 & 0 & 0 & 0 & 0,0 & 0,0 & Resistente \\
\hline PI 90763 & 0 & 0 & 0 & 0 & 0 & 0 & 0,0 & 0,0 & Resistente \\
\hline HARTWIG & 0 & 0 & 0 & 0 & 0 & 0 & 0,0 & 0,0 & Resistente \\
\hline PI 437654 & 0 & 0 & 0 & 0 & 0 & 0 & 0,0 & 0,0 & Resistente \\
\hline Lee 74 & 63 & 34 & 27 & 20 & 37 & 17 & 33,0 & 100,0 & Suscetível \\
\hline
\end{tabular}

* $\mathrm{N}^{\mathrm{o}}$ de Fêmeas/sistema radicular.

$\operatorname{IF}(\%)=($ média de fêmeas na diferenciadora / média de fêmeas em Lee 74) x 100

Suscetível $=$ IF $>$ ou $=10 \%$; Resistente $=$ IF $<10 \%$.

Ficou constatado que a população do NCS pertence à raça 3 . 


\section{ANEXO 2}

Título do Resumo: Nematoides patogênicos às culturas da soja e do milho no Distrito Federal e entorno

Nematodes on soybean and corn crops in Distrito Federal and surrounding areas

Autores: Pedro Victor Verlage Alves 1, Ramón Lira Anjos 1, Nancy Elnice Niño Castañeda 1, JuvenilEnrique Cares 1, Cleber Furlanetto 1.

Instituição: 1 UNB - Universidade de Brasília (Instituto Biológico da UNBDepartamento de Fitopatologia.Laboratório Nematologia).

Áreas produtoras de soja e de milho do Distrito Federal e entorno vem sofrendo com o parasitismo de nematoides. Com o objetivo de se abreviar os danos causados por nematoides nessas culturas, um levantamento tem sido realizado visando identificar os nematoides fitoparasitas presentes nessas áreas. Os nematoides foram extraídos por peneiramento (peneiras de 42, 60 e 400 mesh) e centrifugação. De acordo com os nematoides presentes nas amostras procedeu-se a identificação com base em caracteres morfológicos e morfométricos, fenótipo de esterase e PCR. Foram encontrados os seguintes nematoides fitoparasitas: Heterodera glycines, Meloidogyne sp., Helicotylenchus sp., Pratylenchus brachyurus, Aphelenchus sp.,Aphelenchoides sp., Tylenchus sp., Criconemoides sp., Paratrichodorus sp. e Rotylenchus sp.. Considerando os nematoides fitoparasitas de importância econômica, $H$. glycines foi detectado em 100\% das amostras oriundas de Buritis (MG) e em $40 \%$ das amostras oriundas de Cabeceiras (GO), não tendo sido detectado nas áreas amostradas no DF, com a detecção de até 309 cistos viáveis/300 cc de solo. P. brachyurus foi detectado em $71 \%$ das amostras coletadas em Buritis, 20\% em Cabeceiras e acima de 75\% no DF. M.javanica foi identificado em 29\% das áreas em Buritis. E M. arenaria em 20\% das áreas em Cabeceiras.

Palavras-chaves: fitonematoides, fitopatogênicos, grãos, galha, lesões.

Agência de fomento: UNB

$46^{\circ}$ Congresso Brasileiro de Fitopatologia. 
Título do Resumo: Ocorrência e distribuição de Pratylenchus brachyurus em soja na Região Integrada de Desenvolvimento do Distrito Federal e Entorno - RIDE/DF. Alves, PVV, Oliveira, DP, Niño-Castañeda, NE, Santos, DF, Cares, JE, Furlanetto, C. Universidade de Brasília, Depto. de Fitopatologia, 70.910-900, Brasília-DF. pedrovictorverlage@ hotmail.com. Occurrence and distribution of Pratylenchus brachyurus on soybean in the Integrated Region of the Distrito Federal and Sorrounding Development - RIDE/DF.

A Região Integrada de Desenvolvimento do Distrito Federal e Entorno (RIDE) engloba 22 municípios dos estados de Goiás e Minas Gerais, além do Distrito Federal. Nessa região a soja é a principal cultura econômica e o parasitismo por nematoides um dos principais entraves ao seu desenvolvimento. Com o objetivo de se conhecer a distribuição de Pratylenchus brachyurus nessa região, realizou-se um levantamento com a coleta de solo e raízes de soja. A extração de $P$. brachyurus foi feita pelo método do peneiramento e centrifugação e a identificação realizada com base em caracteres morfológicos e morfométricos. P. brachyurus foi detectado nos municípios goianos de Abadiânia, Água Fria de Goiás, Alexânia, Àguas Lindas de Goiás, Cabeceiras, Cidade Ocidental, Cocalzinho, Corumbá de Goiás, Cristalina, Formosa, Luziânia, Mimoso de Goiás, Padre Bernardo, Planaltina de Goiás e Vila Boa de Goiás. Em Minas Gerais, P. brachyurus foi detectado em Buritis, Cabeceira Grande e Unaí e no Distrito Federal nas Regiões Administrativas do Paranoá (PAD-DF) e Planaltina (Núcleos Rurais de Rio Preto, Tabatinga e Taquara). Detectou-se um máximo de 525 nematoides/300 cc de solo com média de 90 nematoides nas amostras analisadas. Em soja detectou-se um máximo de 71 nematoides/grama de raiz analisada com média de 11,5 nematoides.

Palavras chave: Brasil Central, Cerrado, Glycines max, Nematoide das lesões.

Apoio: UnB, CAPES.

$47^{\circ}$ Congresso Brasileiro de Fitopatologia 